\title{
Efeitos da suplementação de selênio durante a gestação: uma revisão sistemática
}

Aline Brandão Mariath

Dissertação apresentada ao Programa de PósGraduação em Nutrição em Saúde Pública para obtenção do título de Mestre em Ciências.

Área de Concentração: Nutrição em Saúde Pública

Orientadora: Profa. Dra. Denise Pimentel Bergamaschi

São Paulo

2010 
É expressamente proibida a comercialização deste documento, tanto na sua forma impressa como eletrônica. Sua reprodução total ou parcial é permitida exclusivamente para fins acadêmicos e científicos, desde que na reprodução figure a identificação do autor, título, instituição e ano da dissertação. 


\section{Agradecimentos}

Aos meus pais, Luiz e Jacqueline, pelo amor e apoio incondicionais e, acima de tudo, por sempre terem acreditado em seus filhos - tudo o que eu puder fazer por vocês jamais será o suficiente para agradecer!!!

A todos os meus familiares - em especial aos meus avós, Álvaro e Lili (in memorian), Célio e Sônia, meu irmão Eduardo, meus tios Sérgio, Célio e Rita, por terem contribuído, direta ou indiretamente, para a minha formação como ser humano.

Ao Rodrigo, por todo o amor, carinho, apoio e paciência durante essa minha jornada.

À Larissa, Andressa, Mabel e Janaína, minha família em São Paulo.

À Profa. Dra. Denise Pimentel Bergamaschi, que me abriu as portas para o Mestrado e tanto me ensinou nesses últimos dois anos.

À Profa. Dra. Luciane Peter Grillo, a quem serei sempre grata pela oportunidade de iniciar na pesquisa...

Às Profas. Dra. Patrícia Rondó, Dra. Ana Cristina Tanaka, Dra. Simone Grilo Diniz e ao Prof. Dr. Joélcio Abadde pelas significativas contribuições.

Aos meus amigos e colegas de pós-graduação, pela companhia durante os almoços no "bandejão" e cafezinhos no meio da tarde, por todas as nossas conversas e trocas de experiências.

À CAPES, pela bolsa de estudos. 
MARIATH, A. B. Efeitos da Suplementação de selênio durante a gestação: uma revisão sistemática. [Dissertação de Mestrado em Nutrição em Saúde Pública]. São Paulo. Faculdade de Saúde Pública da Universidade de São Paulo; 2010.

Introdução: A nutrição e o estado nutricional maternos na gestação relacionam-se à saúde da mãe e do recém-nascido. O selênio (Se), mineral conhecido especialmente por sua atividade antioxidante, reduz o dano oxidativo celular e tem importante papel no sistema imunológico e no metabolismo tireoidiano. Recentemente, sugeriu-se ainda sua ação como insulino-mimético. Objetivo: Avaliar os efeitos da suplementação de $\mathrm{Se}$ durante a gestação sobre a saúde da mulher e do recém-nascido. Métodos: Foi realizada uma revisão sistemática de literatura na qual incluíram-se estudos com qualquer tipo de desenho metodológico que avaliassem a suplementação de Se isolado em gestantes, independentemente de suas condições de saúde e nutrição, da presença de complicações ou de tratamentos medicamentosos, comparada à administração de placebo ou nenhuma intervenção. Realizou-se a avaliação da qualidade metodológica dos estudos selecionados. Os resultados dessa revisão são apresentados de forma narrativa. Resultados: Quatro estudos foram incluídos. Em três as concentrações plasmáticas ou séricas de Se foram estatisticamente maiores em gestantes suplementadas. Um estudo concluiu que gestantes suplementadas apresentaram maior atividade de glutationa peroxidase. Dois estudos referem aumento estatisticamente significante das concentrações de Se no leite materno de gestantes suplementadas e um verificou concentrações estatisticamente maiores de ácidos monoinsaturados 18:2(n6) e 20:4(n-6) e de poliinsaturados n-6, enquanto a somatória de ácidos graxos saturados foi estatisticamente inferior. $O$ estudo que avaliou morbidade materna, desfechos gestacionais adversos, efeitos colaterais da suplementação, peso ao nascer e escore de APGAR não encontrou efeitos estatisticamente significantes da suplementação. Conclusão: Não existem evidências robustas dos efeitos da suplementação com selênio durante a gestação sobre a saúde da mãe e/ou do recém-nascido. Mais estudos com populações menos específicas e maiores tamanhos amostrais são necessários para que se identifiquem evidências da suplementação na morbidade e mortalidade maternas e do recém-nascido.

Descritores: suplementação alimentar, selênio, gravidez, revisão sistemática. 
MARIATH, A. B. Efeitos da Suplementação de selênio durante a gestação: uma revisão sistemática.l The effects of selenium supplementation during pregnancy: a systematic review [dissertation]. São Paulo (BR). Faculdade de Saúde Pública da Universidade de São Paulo; 2010.

Background: Maternal nutrition and nutritional status during pregnancy are related to maternal and newborn health. Selenium (Se), a mineral well known for its antioxidant activity, reduces oxidative cell damage and plays an important role in immune system and thyroid metabolism. Moreover, an insulin-mimetic action has been recently suggested. Objective: To assess the effects of Se supplementation during pregnancy on maternal and newborn health. Methods: A systematic review of literature was carried out. Studies of any design assessing Se supplementation alone to pregnant women, regardless of their health or nutritional status, of the presence of complications or medical treatment, compared to placebo or no intervention. Methodological quality of studies was appraised. The results of this study are presented in a narrative form. Results: Four studies were included. Three of them found plasma or serum Se levels significantly higher in supplemented pregnant women. One study showed that supplemented pregnant women had significantly higher glutathione peroxidase activity. Two studies referred that Se levels in maternal milk were significantly increased in supplemented women. One study found significantly higher 18:2(n-6) and 20:4(n-6) monounsaturated and n-6 polyunsaturated fatty acid levels and significantly lower total saturated fatty acids in maternal milk. The study that assessed maternal morbidity, adverse pregnancy outcomes, side effects of the intervention birth weight and APGAR score did not find statistically significant effects of the supplementation. Conclusion: There is no strong evidence of the effects of selenium supplementation on maternal and newborn health. Further studies with less specific populations and greater sample sizes are necessary in order to identify evidence of supplementation on maternal and newborn morbidity and mortality.

Key-words: supplementary feeding, selenium, pregnancy, systematic review. 


\section{ÍNDICE}

1 INTRODUÇÃO 10

1.1 O PAPEL FISIOLÓGICO DO SELÊNIO 10

1.1.1 Formação de Enzimas Antioxidantes 11

1.1.2 Função Imunológica $\quad 12$

1.1.3 Metabolismo Tireoidiano 13

1.1.4 Ação Insulino-mimética 14

1.2 O METABOLISMO DO SELÊNIO DURANTE A GESTAÇÃO 16

1.3 O PAPEL DO SELÊNIO NA GESTAÇÃO 17

1.4 RECOMENDAÇÕES NUTRICIONAIS DE SELÊNIO 21

1.5 AVALIAÇÃO DO ESTADO NUTRICIONAL DE SELÊNIO 22

1.6 SUPLEMENTAÇÃO COM SELÊNIO

1.7 REVISÕES SISTEMÁTICAS DE LITERATURA 27

1.8 JUSTIFICATIVA 28

2 OBJETIVOS $\quad 30$

2.1 OBJETIVO GERAL 30

2.2 OBJETIVOS ESPECÍFICOS 30

3 MÉTODOS 31

3.1 PERGUNTA DE PESQUISA 31

3.2 CRITÉRIOS DE INCLUSÃO DE ESTUDOS NO LEVANTAMENTO INICIAL 31

3.2.1 População de Interesse 31

3.2.2 Intervenção de Interesse 32

3.2.3 Comparação de Interesse 32

3.2.4 Desfechos de Interesse $\quad 32$

3.2.5 Desenhos Metodológicos de Interesse 33

3.3 ESTRATÉGIAS PARA A IDENTIFICAÇÃO DE ESTUDOS 34

3.4 COLETA E ANÁLISE DE DADOS 38

3.4.1 Seleção dos Estudos 38

3.4.2 Análise de Qualidade $\quad 39$

3.4.3 Extração de Dados $\quad 40$

3.4.4 Síntese e Análise dos Dados $\quad 42$

3.4.5 Contatos com Autores $\quad 42$

3.4.6 Conflitos de Interesse 43

4 RESULTADOS

44

4.1 BUSCA E SELEÇÃO DOS ESTUDOS

4.2 ANÁLISE DE QUALIDADE 45

4.3 CARACTERÍSTICAS METODOLÓGICAS DOS ESTUDOS INCLUÍDOS 
4.4 CARACTERÍSTICAS DAS POPULAÇÕES DE ESTUDO

4.5 EFEITOS DA SUPLEMENTAÇÃO DE SELÊNIO NOS DESFECHOS RELACIONADOS À GESTANTE/PARTURIENTE 58

4.5.1 Ocorrência de morbidade materna

4.5.2 Ocorrência de desfechos gestacionais adversos

4.5.3 Ocorrência de efeitos colaterais à suplementação

4.5.4 Concentrações plasmáticas e sanguíneas de selênio

4.5.5 Excreção urinária de selênio

4.5.6 Atividade plasmática de glutationa peroxidase

66

4.5.7 Marcadores de estresse oxidativo

4.5.8 Concentrações de selênio no leite materno

4.5.9 Atividade de glutationa peroxidase no leite materno

70

4.5.10 Perfil de ácidos graxos do leite materno

4.6 EFEITOS DA SUPLEMENTAÇÃO DE SELÊNIO NOS

DESFECHOS RELACIONADOS AO RECÉM-NASCIDO

72

4.6.1 Peso ao nascer

4.6.2 Escore de APGAR

72

5 DISCUSSÃO

73

5.1 BUSCA E SELEÇÃO DOS ESTUDOS

5.2 AVALIAÇÃO DE QUALIDADE METODOLÓGICA

5.3 CARACTERÍSTICAS METODOLÓGICAS DOS ESTUDOS 76

5.4 EFEITOS DA SUPLEMENTAÇÃO DE SELÊNIO NOS

DESFECHOS RELACIONADOS À GESTANTE/PARTURIENTE 80

5.4.1 Ocorrência de morbidade materna 80

5.4.2 Ocorrência de desfechos gestacionais adversos $\quad 82$

5.4.3 Ocorrência de efeitos colaterais à suplementação $\quad 84$

5.4.4 Estado nutricional relativo ao selênio $\quad 85$

5.4.5 Marcadores de estresse oxidativo 88

5.4.6 Concentrações de selênio no leite materno 89

5.4.7 Atividade de glutationa peroxidase no leite materno $\quad 90$

5.4.8 Perfil de ácidos graxos no leite materno 91

5.5 EFEITOS DA SUPLEMENTAÇÃO DE SELÊNIO NOS

DESFECHOS RELACIONADOS AO RECÉM-NASCIDO 92

6 CONCLUSÕES

93

7 REFERÊNCIAS $\quad 94$

ANEXOS

ANEXO 1 - Checklist para Avaliação da Qualidade de Estudos do 106 tipo Ensaios Clínicos Aleatorizados Controlados

ANEXO 2 - Checklist for Measuring Study Quality - DOWNS \&

107

BLACK (1998) 


\section{APÊNDICES}

APÊNDICE 1 - Formulário de Avaliação de Resumo

APÊNDICE 2 - Documentação das Buscas nas Bases de Dados

Bibliográficas

111

APÊNDICE 3 - Referências dos Estudos Localizados

122

CURRÍCULOS LATTES 


\section{Lista de Quadros}

Quadro 1 - Funções do selênio de maior destaque durante o período gestacional.

Quadro 2 - Pontos de corte sugeridos para a avaliação da adequação do estado de selênio com base nas concentrações plasmáticas do mineral.

Quadro 3 - Aspectos de interesse para a seleção inicial dos estudos desta revisão sistemática.

Quadro 4 - Classificação dos ensaios clínicos aleatorizados segundo risco de vieses.

Quadro 5 - Classificação dos ensaios clínicos aleatorizados segundo o sigilo de alocação.

Quadro 6 - Características dos estudos não incluídos na etapa de análise de qualidade e principais motivos.

Quadro 7 - Resultados referentes à avaliação da qualidade metodológica dos estudos.

Quadro 8 - Características metodológicas dos estudos incluídos nesta revisão no que se refere ao desenho, à população e à intervenção.

Quadro 9 - Características metodológicas dos estudos incluídos na revisão no que se refere aos principais desfechos avaliados, aos procedimentos analíticos e à análise estatística dos resultados.

Quadro 10 - Comportamento das concentrações de selênio de gestantes que receberam placebo (Preg-Se) ou suplementos de selênio (Preg+Se) durante a gestação e a lactação e de seus controles não gestantes (NonPreg+Se).

Quadro 11 - Comportamento da atividade de glutationa peroxidase em gestantes suplementadas com selênio durante a gestação e a lactação e gestantes sem suplementação. 


\section{Lista de Figuras e Tabelas}

Figura 1 - Processo de seleção de estudos e possíveis razões para a sua não inclusão.

Figura 2 - Distribuição dos trabalhos encontrados segundo base bibliográfica de dados.

Figura 3 - Fluxograma dos resultados da busca, seleção e análise de qualidade dos estudos.

Tabela 1 - Resultados relativos à realização dos testes previstos e às perdas de seguimento do estudo de NEGRO e col. (2007).

Tabela 2 - Presença de tireoidite nas gestantes TPOAb+ que receberam placebo (SO) e TPOAb+ suplementadas com selênio (S1). 


\section{INTRODUÇÃO}

A nutrição e o estado nutricional da mulher durante a gestação podem ter um impacto profundo e duradouro tanto na sua saúde como no desenvolvimento e bem estar do feto, do recém-nascido e da criança (BLACK, 2001; ALLEN, 2005; HONG e col., 2007). Nesse período, fatores nutricionais podem influenciar a função placentária, incluindo sua estrutura vascular, a eficiência dos sistemas de transportes placentários e a divisão dos nutrientes entre mãe, placenta e feto, desempenhando consequentemente um importante papel no crescimento fetal (FALL e col., 2003). Por isso, o estudo da influência da ingestão de nutrientes na saúde durante a gestação, quando estratégias de prevenção e tratamento de doenças e deficiências nutricionais precisam ser utilizadas, reveste-se de interesse na área clínica e de saúde pública (GLENVILLE, 2006).

\subsection{O PAPEL FISIOLÓGICO DO SELÊNIO}

O selênio é um mineral conhecido principalmente por suas atividades antioxidante e antiinflamatória e suas propriedades quimiopreventivas e antivirais (PAPPAS, 2008). É essencial para a síntese e função de selenoproteínas, que desempenham um papel relevante na defesa antioxidante e auxiliam na redução do dano oxidativo (TAPIERO e col., 2003; LEI e col., 2007; NAVARRO-ALARCON e CABRERA-VIQUE, 2008; PAPPAS, 2008; RAVN-HAREN e col., 2008). Participa ainda do metabolismo da tireóide e da glicose, da imunidade e da função reprodutiva (BATTELL e col., 1998; FORCEVILLE, 2006; FLOHÉ, 2007; PAPPAS, 2008). É reconhecido que a deficiência do mineral está implicada na etiologia das doenças de Keshan e Kashin-Beck, mas a literatura também descreve que o 
seu baixo estado nutricional e a atividade alterada da glutationa peroxidase, enzima antioxidante dependente de selênio, podem estar associados à etiologia e à progressão de diversas outras doenças crônicas, incluindo o câncer, cardiopatias, diabetes mellitus, doenças neurodegenerativas e hepáticas e HIVIAIDS (MORENO-REYES e col., 1998; TAN e col., 2001; LEI e col., 2007; HOFFMANN e BERRY, 2008; NAVARRO-ALARCON e CABRERA-VIQUE, 2008).

Apresentam-se a seguir, com mais detalhes, as funções fisiológicas do selênio que parecem ser mais relevantes durante o período gestacional.

\subsubsection{Formação de Enzimas Antioxidantes}

O selênio exerce sua principal função metabólica ao participar da síntese e função das selenoproteínas após ser incorporado na selenocisteína. Dentre a grande variedade já descrita de selenoproteínas que possuem função antioxidante estão as glutationas peroxidases, a selenoproteína $\mathrm{P}$ e a tioredoxina redutase. Aumentos na sua expressão podem levar a reduções do dano oxidativo ao DNA, lipídios e proteínas (TAPIERO e col., 2003; LEI e col., 2007; NAVARRO-ALARCON e CABRERA-VIQUE, 2008; RAVN-HAREN e col., 2008).

Nas enzimas glutationa peroxidases, o selênio atua como um co-fator. As glutationa peroxidases dependentes de selênio reduzem peróxidos, incluindo os de hidrogênio e os lipídicos (LEI e col., 2007; NAVARROALARCON e CABRERA-VIQUE, 2008), por conseguinte mantendo a peroxidação intracelular apropriadamente reduzida e minimizando o dano à membrana e a outras estruturas celulares causado pelos radicais livres (TAPIERO e col., 2003). Seu papel fisiológico na proteção contra o estresse oxidativo causado por espécies reativas de oxigênio depende tanto do estado nutricional relativo ao selênio quanto do grau do estresse (LEI e col., 2007). A deficiência de selênio, por outro lado, ao reduzir as atividades das enzimas glutationa peroxidase e glutationa peroxidase hidroperóxido, leva ao aumento da produção de prostaglandinas e da formação de tromboxanos, 
resultando em episódios inflamatórios e trombóticos e em lesão vascular (PARKE, 1999).

A selenoproteína $\mathrm{P}$ é um antioxidante extracelular que reduz espécies reativas de nitrogênio no endotélio vascular. Juntamente com a glutationa peroxidase, está envolvida na regulação da atividade inflamatória (NAVARRO-ALARCON e CABRERA-VIQUE, 2008).

O selênio também participa da produção da tioredoxina redutase, enzima que reduz substratos intracelulares, regula outras enzimas antioxidantes, modula fatores de transcrição, regula a apoptose e modula a fosforilação protéica (NAVARRO-ALARCON e CABRERA-VIQUE, 2008; PAPPAS, 2008).

\subsubsection{Função Imunológica}

A ingestão adequada de selênio é essencial para a atividade do sistema imunológico e, consequentemente, sua deficiência relaciona-se à perda de imunocompetência. Ao aturarem como antioxidantes no espaço extracelular, no citosol, em conjunto com as membranas celulares ou no trato gastrointestinal, as selenoenzimas inibem o metabolismo celular próinflamatório e melhoram as respostas inflamatórias. Linfócitos deficientes em selênio apresentam dificuldade para responder aos antígenos e a deficiência do mineral prejudica a produção de leucotrieno B4, substância essencial para a ação atrativa dos neutrófilos, pelos macrófagos. Embora a deficiência de selênio não necessariamente reduza o número de neutrófilos, acredita-se que a redução da atividade da glutationa peroxidase no citosol possa comprometer alguns aspectos de sua função. Em humanos, o sistema imune humoral também é prejudicado pela deficiência do mineral, podendo levar a uma redução das imunoglobulinas $\lg$ e $\lg$ (ARTHUR e col., 2003; FORCEVILLE, 2006).

Assim, mesmo deficiências leves de selênio poderiam aumentar a susceptibilidade a doenças e comprometer a manutenção da saúde. Embora o baixo estado nutricional do mineral possa contribuir para a etiologia de 
doenças, em alguns casos pode ser um resultado da própria doença e acelerar sua progressão, como ocorre na infecção pelo HIV (RAYMAN, 2000; THOMSON, 2004).

O selênio parece ter uma atuação variada sobre os diferentes tipos de resposta imunológica. No caso de infecções virais, dentre elas a doença de Keshan, a influenza A, a infecção pelo HIV e a poliomielite, sua deficiência aumenta a susceptibilidade do hospedeiro. No caso da influenza, por exemplo, o selênio parece ter uma maior influência sobre a imunidade mediada por células do que sobre a imunidade humoral. Nas infecções nãovirais, os efeitos do estado de selênio parecem depender do microorganismo envolvido. (HOFFMANN e BERRY, 2008).

\subsubsection{Metabolismo Tireoidiano}

Os parâmetros séricos dos hormônios tireoidianos são alterados em diversas condições fisiológicas onde há um desequilíbrio no estado de selênio (KÖHRLE, 2005). Isso ocorre porque a ativação e a inativação dos hormônios tireoidianos são catalisadas por enzimas oxidorredutases que contêm selênio. A iodotironina deiodinase, enzima que possui selênio em sua composição, participa do metabolismo da tireóide, convertendo a tiroxina em triiodotironina (KÖHRLE, 2005; PAPPAS, 2008). Os hormônios tireoidianos, por sua vez, regulam uma infinidade de processos metabólicos, dentre eles a termogênese, o crescimento e a audição, indispensáveis para o desenvolvimento cerebral fetal. Acredita-se que, especialmente no início da gestação, a redução das atividades da iodotironina deiodinase e da glutationa peroxidase possa estar implicada na ocorrência de atraso no desenvolvimento mental (PAPP e col., 2007; GYAMFI e col., 2009).

O hipotireoidismo pode ainda ter efeitos adversos sobre a função imunológica uma vez que, em geral, reduz a habilidade dos neutrófilos para reagir contra patógenos (ARTHUR e col., 2003).

Por outro lado, com a ingestão excessiva de selênio, observa-se um prejuízo na regulação dos hormônios tireoidianos, com reduções típicas nos 
níveis séricos de triiodotironina. Quando o suprimento tanto de iodo quanto de selênio é inadequado, o metabolismo dos hormônios da tireóide se readapta para aumentar a retenção de selênio no cérebro, nos tecidos endócrinos e especialmente na tireóide, e de iodo na tireóide (KÖHRLE, 2005).

\subsubsection{Ação Insulino-mimética}

A literatura descreve que o selênio exerce efeitos na regulação do metabolismo da glicose (BATTELL e col., 1998). Relata-se que o mineral pode ser considerado um agente insulino-mimético, que imita a ação da insulina, promovendo a entrada da glicose nos tecidos para que esta possa ser convertida em energia ou armazenada na forma de lipídios (STAPLETON, 2000).

O selênio já se mostrou um bom agente mimético tanto em estudos in vitro quanto in vivo, podendo estimular o transporte de glicose de formas dose e tempo-dependentes. O aumento no transporte de glicose promovido pelo mineral pode ser atribuído à transferência dos transportadores de glicose para a superfície da membrana celular. Foi descrito que o selênio é capaz de reduzir a glicemia de forma semelhante à insulina, consequentemente regulando o destino da glicose por meio do estímulo à glicólise, à síntese de ácidos graxos e, em alguns casos, à síntese de glicogênio. Ao ativar a via de transdução de sinal da insulina, o selênio aumenta a expressão de enzimas importantes envolvidas no metabolismo da glicose (STAPLETON, 2000). A regulação do transporte da glicose e o efeito anti-lipolítico promovidos pelo selênio, apesar de configurarem como funções reguladas pela insulina, ocorrem de forma independente do receptor desse hormônio (HEART e SUNG, 2003).

Evidências experimentais apontam que, na presença de diabetes, o selênio é capaz não apenas de reduzir significativamente a glicemia, mas também de aumentar a atividade de glutationa peroxidase, mesmo sem aumento dos níveis plasmáticos de insulina (ZENG e col., 2009). Segundo 
STAPLETON (2009), o selênio também pode reverter anormalidades na expressão hepática de enzimas glicogênicas e gliconeogênicas, além de melhorar a função cardíaca e o perfil dos lipídios plasmáticos, incluindo os triglicerídeos, o colesterol e os ácidos graxos livres. O selênio poderia também inibir a formação de moléculas de adesão promovidas pela hiperglicemia e pela insulinemia, consequentemente exibindo um efeito antiaterosclerótico (ZHENG e col., 2008).

Resumem-se no Quadro 1 as funções do selênio anteriormente descritas.

Quadro 1 - Funções do selênio de maior destaque durante o período gestacional.

\begin{tabular}{|c|l|}
\hline Função Fisiológica & Descrição \\
\hline \multirow{2}{*}{$\begin{array}{c}\text { Formação de } \\
\text { enzimas } \\
\text { antioxidantes }\end{array}$} & $\begin{array}{l}\text { Participação na síntese e função de } \\
\text { selenoproteínas, dentre as quais se destacam as } \\
\text { glutationas peroxidases, a selenoproteína P a a } \\
\text { tioredoxina redutase, com importante função } \\
\text { antioxidante. }\end{array}$ \\
\hline \multirow{2}{*}{$\begin{array}{c}\text { Função imunológica } \\
\text { Metabolismo }\end{array}$} & $\begin{array}{l}\text { Pelhora das respostas inflamatórias, participação na } \\
\text { função de linfócitos e neutrófilos. }\end{array}$ \\
\hline Tireoidiano & $\begin{array}{l}\text { catalisam os processos de ativação e inativação dos } \\
\text { hormônios tireoidianos (tiroxina e triiodotironina). }\end{array}$ \\
\hline \multirow{2}{*}{$\begin{array}{c}\text { Ação Insulino- } \\
\text { mimética }\end{array}$} & $\begin{array}{l}\text { Promoção de entrada da glicose nos tecidos para } \\
\text { sua conversão em energia ou armazenamento em } \\
\text { forma de lipídios, de forma semelhante à insulina. }\end{array}$ \\
\hline
\end{tabular}




\subsection{O METABOLISMO DO SELÊNIO DURANTE A GESTAÇÃO}

A literatura sobre o estado de selênio durante a gestação indica redução progressiva em suas concentrações neste período, sejam elas séricas, sangüíneas ou no cabelo, independentemente da presença ou não de complicações gestacionais (PERONA e col.,1979; DISON e col., 1993; GROMADZINSKA e col., 1998; REYES e col., 2000; TAN e col., 2001; WASOWICZ e col., 2003; McLACHLAN e col., 2004; PINHEIRO e col., 2005; DESAI e col., 2006). Existem pelo menos três possíveis explicações para esta redução: i) poderia ser uma conseqüência da hemodiluição causada pela expansão do plasma materno (FERRER e col., 1999; KANTOLA e col., 2004); ii) poderia refletir o transporte de selênio para o feto (KANTOLA e col., 2004), já que as concentrações séricas de selênio no cordão umbilical aumentam com a progressão da gestação (MAKHOUL e col., 2004); iii) é possível que neste período uma maior quantidade de selênio seja utilizada para a produção de compostos antioxidantes como a glutationa peroxidase e a selenoproteína $\mathrm{P}$, o que por sua vez explicaria a redução do sistema de defesa antioxidante normalmente observada durante a gestação (MUKHERJEE e col., 1998; MIHAILOVIC e col., 2000).

Em um estudo acerca do metabolismo do selênio, SWANSON e col. (1983) estimaram, com base na excreção fecal de selênio, que para mulheres gestantes e não gestantes, independentemente do período gestacional, a absorção do selênio consumido é de cerca de $80 \%$. Nas gestantes, os autores descrevem uma tendência de redução na excreção urinária de selênio, o que indicaria uma regulação fisiológica para permitir o acúmulo do mineral no organismo. 


\subsection{O PAPEL DO SELÊNIO NA GESTAÇÃO}

Encontram-se na literatura estudos que investigam a relação entre o selênio e as condições de saúde da mãe e do recém-nascido, principalmente quanto à ocorrência de diversos desfechos gestacionais adversos, dentre os quais podem ser citados os abortos espontâneos e os partos prematuros (BARRINGTON e col., 1996; DOBRZYNSKI e col., 1998; AL-KUNANI e col., 2001; DESAI e col., 2006). Reduções nas concentrações séricas de selênio maternas poderiam ainda estar relacionadas à ocorrência de defeitos do tubo neural (CENGIZ e col., 2004) e a baixa ingestão dietética de selênio poderia estar associada à ocorrência de hérnia diafragmática congênita (YANG e col., 2008).

Pesquisas indicam que as concentrações de selênio de recémnascidos pré-termo e a termo estão relacionadas ao estado de selênio de suas mães (DISON, e col., 1993; DOBRZYNSKI e col.,1998; MICETICTURK e col., 2000), e ainda que recém-nascidos pré-termo nascidos de gestantes saudáveis apresentam menores concentrações do mineral quando comparados a recém-nascidos a termo (AL-SALEH e col., 1998). Recémnascidos pré-termo podem também apresentar redução da atividade eritrocitária da glutationa peroxidase, enzima dependente de selênio, que por sua vez estaria relacionada a uma maior incidência de dependência de oxigênio no $28^{\circ}$ dia de vida (MENTRO e col., 2005). Esta redução da atividade antioxidante seria decorrente do baixo estado de selênio.

Ainda há muita controvérsia acerca da relação entre o estado de selênio de recém-nascidos e o peso ao nascer (PERONA e col.,1979; BRO e col., 1998; ODLAND e col.,1999; KANTOLA e col., 2004; MAKHOUL e col., 2004; BOGDEN e col., 2006). No entanto, há relato de que possa haver não somente uma relação entre o peso ao nascer, a idade gestacional e as concentrações de selênio, mas também entre peso ao nascer, idade gestacional e a atividade de glutationa peroxidase (DISON e col., 1993). 
A literatura sugere ainda que, na presença de pré-eclâmpsia (complicação caracterizada por hipertensão induzida pela gestação, anasarca e proteinúria), haveria uma redução do potencial antioxidante, acompanhada por uma redução nas concentrações plasmáticas de selênio maternas. Um estudo caso-controle com gestantes do Reino Unido encontrou que baixas concentrações de selênio nas unhas dos pés, que refletiriam o estado nutricional do mineral nos 3 a 12 meses anteriores, estariam associadas a uma incidência 4,4 vezes maior de pré-eclampsia. Entre as gestantes com essa condição, menores concentrações de selênio estiveram associadas a uma maior ocorrência de partos prematuros (idade gestacional inferior a 32 semanas) (RAYMAN e col., 2003). O estudo de DAWSON e col. (1999) apontou que gestantes com pré-eclampsia apresentavam concentrações de selênio $30 \%$ inferiores às gestantes saudáveis ao início do terceiro trimestre, embora não houvesse diferença quando comparadas as gestações ao final do terceiro trimestre.

Esta relação entre menores concentrações de selênio e a ocorrência de pré-eclampsia parece estender-se aos filhos destas gestantes, havendo relatos tanto de concentrações reduzidas de selênio no sangue do cordão umbilical de bebês nascidos de mulheres com esta condição (MISTRY e col., 2008) quanto de redução de sua atividade de glutationa peroxidase (TASTEKIN e col., 2005).

$\mathrm{Na}$ presença de intolerância à glicose e de diabetes gestacional, poderia ocorrer uma redução acentuada das concentrações de selênio das gestantes (TAN e col., 2001; MOLNAR, 2008). KILINC e col. (2008) conduziram um estudo que incluiu gestantes com intolerância à glicose, diabetes gestacional e seus respectivos controles normais. Os autores observaram reduções significativas nas concentrações séricas de selênio das mulheres com intolerância à glicose e diabetes gestacional. BO e col. (2005) também descreveram concentrações séricas de selênio significativamente menores em gestantes hiperglicêmicas, conquanto não tenham sido observadas associações entre as concentrações maternas de selênio e desfechos como percentual de cesarianas, crianças pequenas ou 
grandes para a idade gestacional, nascimentos pré-termo e morbidades neonatais.

Durante a gestação, as concentrações plasmáticas de selênio poderiam estar inversamente relacionadas à glicemia de jejum e à glicemia após carga oral de glicose. Pode haver também uma relação inversa entre a glicemia de jejum e a atividade de glutationa peroxidase (HAWKES e col., 2004). Segundo SURAPANENI (2007), as menores concentrações de glutationa observadas em gestantes diabéticas poderia ser um reflexo do aumento do estresse oxidativo que, por sua vez, relaciona-se a todos os tipos de diabetes, incluindo o gestacional e a suas complicações (LEI e col., 2007).

É importante destacar, todavia, que mesmo em gestações normais pode haver um aumento nas concentrações sangüíneas de insulina e glicose, embora estas permaneçam dentro do nível de normalidade. $O$ aumento destas substâncias pode estar acompanhado de uma elevação na concentração de glutationa peroxidase (CHEN e col., 2008).

Em adição, considerando-se o aumento transitório no estresse oxidativo durante o período gestacional, indicado especialmente por reduções das concentrações de selênio e da atividade da glutationa peroxidase (DISON e col., 1993; HOLMES e McCANCE, 2005; MIHAILOVIC e col., 2000), o estado de selênio pode ter um papel devido às suas funções antioxidantes. Há relatos na literatura que a melhoria do estado antioxidante materno poderia trazer benefícios adicionais ao feto, tendo em vista que o estresse oxidativo e o desequilíbrio da atividade oxidante/antioxidante nos tecidos placentários estariam implicados no desenvolvimento de doenças relacionadas à placenta (JANIAUX e col., 2006) e que o estresse oxidativo da mãe pode estar relacionado ao da criança (KOKLU e col., 2007). Além disso, apesar de a produção de radicais livres ocorrer continuamente em todas as células, quando em excesso estes podem ter um importante papel em diversas doenças (ORHAN e col., 2003; HOLMES e McCANCE, 2005).

Encontra-se documentada na literatura a relação entre o estresse oxidativo aumentado e a ocorrência de complicações gestacionais, que 
incluem abortos, pré-eclampsia, diabetes gestacional, náuseas e vômitos, restrição de crescimento intrauterino e ruptura prematura de membrana (DOBRZYNSKI e col., 1998; HOLMES e McCANCE, 2005; BIRI e col., 2006; CHAMY e col., 2006; DENNERY, 2007; GRISSA e col., 2007; KAROWICZBILINSKA e col., 2007; KOKLU e col., 2007; LONGINI e col., 2007; VERIT e col., 2007; MEHENDALE e col., 2008). Apesar de seus mecanismos não estarem completamente elucidados, o estresse oxidativo poderia contribuir para a programação fetal, já que tanto o crescimento fetal insuficiente quanto o excessivo estão associados ao aumento do risco futuro de doenças crônicas (LUO e col., 2006).

Considerando-se o papel do selênio na progressão e virulência do vírus HIV, KUPKA e col. (2004) observaram que elevadas concentrações plasmáticas do mineral em gestantes poderiam ser importantes para a redução da mortalidade materna e para a manutenção das concentrações de células CD4. O mesmo grupo de pesquisadores encontrou que filhos de mulheres HIV positivas com baixas concentrações de selênio apresentam maior risco de morte fetal, de morte infantil nos 24 meses de vida (especialmente entre crianças não infectadas pelo HIV) e de transmissão do HIV durante o parto e no início da amamentação. Parece ainda haver uma associação positiva entre as concentrações maternas de selênio e o risco de a criança nascer pequena para a idade gestacional (KUPKA e col., 2005).

É preciso ressaltar, contudo, que o papel do selênio na etiologia de doenças não está totalmente esclarecido e que os estudos conduzidos até o momento apresentam tamanhos de amostra pequenos e não possuem desenhos que estabeleçam relações de causa e efeito. Assim, como bem colocam NAVARRO-ALARCON e CABRERA-VIQUE (2008), baixas concentrações do mineral poderiam ser tanto uma causa subjacente quanto uma conseqüência da própria doença.

Mesmo na possibilidade de o selênio ser causa ou efeito na ocorrência dos eventos citados, seria esperado que a correção do baixo estado do mineral poderia contribuir tanto para saúde materna quanto da criança. 


\subsection{RECOMENDAÇÕES NUTRICIONAIS DE SELÊNIO}

As recomendações de selênio baseiam-se na quantidade necessária do mineral para otimizar a função da glutationa peroxidase. Durante a gestação, a ingestão dietética deve ser incrementada de modo que forneça quantidade de selênio suficiente para assegurar a quantidade necessária para o metabolismo materno e permitir que quantidades satisfatórias do mineral sejam transferidas para o feto, saturando suas selenoproteínas. Neste período, a necessidade média estimada (Estimated Average Requirement, EAR) aumenta cerca de $4 \mu \mathrm{mg}(0,05 \mu \mathrm{mol})$ selênio/dia, alcançando uma recomendação de $49 \mu \mathrm{mg} \quad(0,62 \mu \mathrm{mol})$ selênio/dia, independentemente da idade materna. A quota dietética recomendada (Recommended Dietary Allowance, RDA), valor diário médio que supriria as necessidades do mineral em 97 a $98 \%$ dos indivíduos saudáveis de uma população, por sua vez, é de $60 \mu \mathrm{mg}(0,76 \mu \mathrm{mol})$ selênio/dia (INSTITUTE OF MEDICINE, 2000).

Apesar de o selênio estar amplamente distribuído em alimentos de origem animal e vegetal, tais como carnes, frutos do mar, grãos, produtos lácteos, frutas e vegetais, o seu conteúdo nos alimentos depende de sua disponibilidade no solo onde as plantas são cultivadas e os animais são criados. A acidez do solo e a complexação do mineral, frequentemente com ferro e alumínio, reduzem sua absorção pelas plantas, como pode ser observado em muitas regiões da Europa. Esses fatores acarretam em uma grande variabilidade na sua ingestão entre diferentes populações, dependendo especialmente da origem dos produtos alimentícios consumidos. Sua deficiência é rara, sendo geralmente encontrada em locais onde o solo é pobre no mineral, como em áreas vulcânicas, por exemplo (INSTITUTE OF MEDICINE, 2000; RAYMAN, 2000).

Consequentemente, elevadas prevalências de deficiência de selênio são incomuns e não há estimativas mundiais da magnitude de sua carência. No entanto, alguns estudos que avaliaram a ingestão dietética de selênio 
durante a gestação encontraram níveis abaixo das recomendações (MATHEWS e NEIL, 1998; MICETIC-TURK e col., 2000; McLACHLAN e col., 2004; NICHOLS e col., 2008; DERBYSHIRE e col., 2009), principalmente em populações que residem em áreas onde o solo é deficiente. Em países como a Suíça, por exemplo, a adequação do estado de selênio é alcançada por meio do consumo de trigo americano, rico em selênio por sua biodisponibilidade no solo em que é produzido, enquanto na Finlândia os fertilizantes são enriquecidos com selênio desde 1984 (EICHHOLZER, 2003; KANTOLA e col., 2004).

Já foi relatado que, mesmo com o uso de suplementos nutricionais, muitas gestantes podem não alcançar as recomendações, especialmente porque muitos suplementos comumente utilizados nesse período não contêm selênio (MATHEWS e NEIL, 1998). Em geral, embora mulheres que planejam engravidar possam apresentar consumo de selênio maior que aquelas que não planejam, sua ingestão pode encontrar-se abaixo das recomendações (DE WEERD e col., 2003).

\subsection{AVALIAÇÃO DO ESTADO NUTRICIONAL DE SELÊNIO}

Dentre as técnicas mais comumente utilizadas para avaliar o estado nutricional de selênio podem ser citadas a estimativa da ingestão do mineral, a quantificação das concentrações de selênio no sangue, tecidos ou excreta e a determinação da atividade de glutationa peroxidase em diversos componentes sanguíneos (HOLBEN e SMITH, 1999).

Registros dietéticos podem estimar padrões de ingestão de selênio de um indivíduo ou população e identificar dentre os alimentos consumidos aqueles que constituem boas fontes do mineral. Este método, contudo, pode não refletir a ingestão real, tendo em vista a variabilidade do conteúdo de selênio no solo (HOLBEN e SMITH, 1999). 
Os indicadores mais utilizados para a avaliação do estado nutricional de selênio são as concentrações plasmáticas e séricas do mineral, sendo que concentrações acima 1,27 $\mu \mathrm{mol} / \mathrm{L}(100 \mu \mathrm{mg} / \mathrm{dL})$ indicam a maximização das selenoproteínas plasmáticas e refletem o estado em curto prazo. Para uma estimativa do estado de selênio em longo prazo, podem ser utilizadas as suas concentrações nos eritrócitos ou células vermelhas (THOMSON, 2004).

A concentração de selênio nas unhas reflete a ingestão do mineral de aproximadamente 6 a 12 meses antes da coleta da amostra. Maiores ingestões de selênio, que levam à saturação das demandas metabólicas, fazem com que o mineral tenda a se acumular de forma dose-resposta. Todavia, embora alguns estudos avaliem concentrações de selênio em unhas e cabelos, estas podem não ser bons indicadores do estado nutricional do mineral na medida em que dependem de fatores tais como a forma em que este é ingerido, a quantidade do aminoácido metionina na dieta, a cor do cabelo e a presença de selênio em produtos cosméticos (HOLBEN e SMITH, 1999; INSTITUTE OF MEDICINE, 2000).

Em relação à excreção urinária de selênio, o fato de esta ser sensível a mudanças na ingestão em curto prazo faz com que seja útil apenas para verificar a adequação da ingestão recente, mas não para a avaliação do estado nutricional. Somente em populações com baixo consumo do mineral a excreção urinária apresenta forte associação com o selênio plasmático e a ingestão dietética (INSTITUTE OF MEDICINE, 2000; THOMSON, 2004).

As atividades plasmática e eritrocitária de glutationa peroxidase guardam relação com as concentrações totais de selênio, sendo a plasmática um melhor indicador que a eritrocitária (INSTITUTE OF MEDICINE, 2000; THOMSON, 2004). Essas medidas são úteis, contudo, apenas para a avaliação de indivíduos com baixo estado de selênio, já que a atividade máxima dessa enzima é capaz de ser alcançada com concentrações sanguíneas de selênio acima de 1,27 $\mu \mathrm{mol} / \mathrm{l}(100 \mu \mathrm{g} / \mathrm{l})$, como anteriormente mencionado. Assim, a utilização da atividade da glutationa peroxidase como marcador dos efeitos da suplementação com diferentes 
formas de selênio é apropriada apenas para indivíduos com baixo estado nutricional do mineral. A sua atividade plaquetária de parece ser o indicador mais sensível do aumento da ingestão de selênio, sendo possível verificar aumentos a partir de 1 a 2 semanas do início da suplementação (THOMSON, 2004).

A avaliação individual de selenoproteínas pode fornecer informações mais úteis e precisas que a medida total de selênio. No entanto, a determinação de uma única selenoproteína pode ser insuficiente e gerar conclusões equivocadas (THOMSON, 2004). Estudos sugerem que a selenoproteína $\mathrm{P}$ poderia ser um bom marcador bioquímico do estado de selênio, havendo possibilidade de utilização de outras enzimas como marcadores funcionais. Questiona-se, contudo, se uma única selenoproteína refletiria adequadamente todas as funções biológicas do selênio, face às distintas respostas dos tecidos e das próprias selenoproteínas a diferentes níveis do mineral. Desta forma, é pouco provável que haja um só indicador do estado funcional de selênio, mas sim um conjunto de marcadores que refletiriam problemas específicos associados a um estado sub-ótimo do mineral. Além disso, a única proteína funcional para a qual se dispõem de dados suficientes em humanos é a glutationa peroxidase (THOMSON, 2004).

ASHTON e col. (2009) avaliaram por meio de uma revisão sistemática de literatura a utilidade dos marcadores do estado nutricional relativo ao selênio em humanos saudáveis, com base nas mudanças no estado do mineral provocadas pela sua suplementação na forma orgânica (selenometionina e levedura enriquecida com selênio). Os autores sugerem que as concentrações plasmáticas, eritrocitárias e sanguíneas de selênio, a concentração plasmática de selenoproteína $\mathrm{P}$ e a atividade plasmática, sanguínea e plaquetária de glutationa peroxidase são possivelmente marcadores úteis do estado nutricional relativo ao selênio. Destacam, porém, que existe uma grande heterogeneidade entre os estudos no que diz respeito à resposta à suplementação para todos os marcadores avaliados e apontam a necessidade de mais estudos com maior rigor metodológico. 
A grande variabilidade dos valores das concentrações séricas ou plasmáticas de selênio dificulta o estabelecimento de níveis universalmente aceitos para a avaliação da adequação do estado do mineral. Dessa forma, THOMSON (2004), com base em critérios e argumentos similares àqueles propostos para a estimação das necessidades de selênio, sugere alguns pontos de corte para se avaliar a adequação do estado de selênio por meio das concentrações plasmáticas do mineral.

Quadro 2 - Pontos de corte sugeridos para a avaliação da adequação do estado de selênio com base nas concentrações plasmáticas do mineral.

\begin{tabular}{lc}
\hline & Concentração de Se $(\mu \mathrm{mol} / \mathrm{l})$ \\
\hline Prevenção de Doença de Keshan & $>0,25$ \\
Otimização da atividade das iodotironinas deiodinases & $>0,82$ \\
Maximização da glutationa peroxidase e selenoproteína P plasmáticas & 1,00 a 1,20 \\
Proteção contra alguns tipos de câncer & $>1,5$
\end{tabular}

Fonte: extraído de THOMSON, 2004.

\subsection{SUPLEMENTAÇÃO COM SELÊNIO}

Por diversas razões, a selenometionina é considerada a melhor forma de suplementação de selênio. Este composto é o mais frequentemente encontrado em gêneros alimentícios, especialmente aqueles utilizados como base alimentar de populações. É bem absorvido (mais de 90\%) e pode ser diretamente metabolizado em proteínas corporais. A selenometionina também é encontrada em fermento de levedura rico em selênio, produzido quando o fermento é cultivado em áreas onde o mineral encontra-se em abundância no solo.

Embora a selenometionina seja a principal forma dietética do selênio e a melhor forma de suplementá-lo, as formas inorgânicas do mineral, selenito e selenato, são amplamente utilizadas na fortificação de alimentos e como suplementos. A absorção do selenato é bem eficiente, enquanto 
apenas $50 \%$ do selenito consumido são absorvidos (INSTITUTE OF MEDICINE, 2000; SCHRAUZER, 2001).

A absorção de todas as formas do mineral é relativamente elevada, mas pode variar de acordo com o estado de selênio do indivíduo. Ainda que os seus sais selenito e selenato e a selenocisteína sejam facilmente incorporados na forma de selenoproteínas, estes podem ser acumulados de forma limitada. Tendo em vista que a selenometionina pode substituir a metionina e ser armazenada nas proteínas como os músculos, seu acúmulo é superior àquele da selenocisteína e dos sais de selênio (FINLEY, 2006).

$\mathrm{Na}$ gestação, as intervenções geralmente incluem doses diárias na forma de tabletes ou cápsulas contendo até $200 \mu \mathrm{g}$ de selênio elementar (selenometionina). O período de suplementação pode variar, e a intervenção pode ser realizada desde o período pré-natal até o pós-parto (MOORE e col., 2000; NEGRO e col., 2007; KUPKA e col., 2008; KUPKA e col., 2009). As doses suplementares de até $200 \mu \mathrm{g}$ do mineral (quatro vezes a EAR para gestantes) não deveriam provocar efeitos adversos, mesmo se temporariamente excedidas, uma vez que o nível máximo de ingestão tolerável (Upper Tolerable Intake, UL) estabelecido para este grupo é de 400 $\mu \mathrm{g}(5,1 \mu \mathrm{mol})$ selênio/dia. Em adição, a homeostase corporal de selênio pode ser mantida através da excreção urinária (INSTITUTE OF MEDICINE, 2000).

Considerando-se o elevado valor da UL para o selênio e a possibilidade de regulação de sua homeostase corporal, pode-se considerar que a suplementação com selênio é uma intervenção segura. Efeitos adversos ou colaterais são facilmente reconhecidos e incluem perda de cabelos, enfraquecimento de unhas, distúrbios gastrointestinais, lesões de pele, hálito com odor de alho, fadiga, irritabilidade e anormalidades do sistema nervoso central, não sendo relatados com frequência (INSTITUTE OF MEDICINE, 2000; SCHRAUZER, 2001). Há registros de ocorrência de sinais clínicos de selenose com ingestões entre 1200 e $5000 \mu \mathrm{g} / \mathrm{d}$ e alterações bioquímicas (aumento do tempo de protrombina plasmática e redução das concentrações sanguíneas de glutationa) com ingestões que variavam de 700 a $850 \mu \mathrm{g} /$ dia do mineral (SANDSTROM, 1998). 


\subsection{REVISÕES SISTEMÁTICAS DE LITERATURA}

Revisões sistemáticas permitem que se encontre o maior nível de evidência de um determinado tema, na medida em que utilizam métodos explícitos e reprodutíveis para a busca, a análise crítica e a síntese de resultados de estudos. São comumente utilizadas para a identificação e avaliação dos efeitos de intervenções ou exposições sobre a saúde humana (SILVA FILHO e col., 2005; PETERS e col., 2006).

Seus resultados permitem a atualização de profissionais de saúde e subsidiam a tomada de decisões e o desenvolvimento de diretrizes para práticas de saúde. Podem ser úteis para gestores de políticas públicas ou para pessoas que busquem informações acerca de diferentes tratamentos. Ajudam também a resolver questões controversas, levantar novas hipóteses de estudo, apontar áreas onde mais pesquisas sejam necessárias e identificar intervenções benéficas ou nocivas muito antes dos outros tipos de revisão de literatura (KLASSEN e col., 1998; The Plos Medicine Editors, 2007; LAUPACIS e STRAUS, 2007; MOHER e col., 2007).

O número cada vez maior de revisões sistemáticas publicadas reflete o crescente interesse por estudos deste tipo. Um dos fatores que podem estar implicados nesse interesse é o rigor metodológico com que estas são conduzidas, por meio de passos bem definidos e específicos que incluem: a elaboração da pergunta de pesquisa, o pré-estabelecimento dos critérios para a inclusão dos estudos, a definição das bases de dados e das estratégias de busca, a seleção dos estudos elegíveis e sua análise de qualidade, além da extração, síntese e análise dos dados, podendo ou não ser realizados agrupamentos estatísticos de resultados (metanálises). Estes passos metodológicos constituem um grande diferencial das revisões sistemáticas em relação às revisões tradicionais ou narrativas (KLASSEN e col., 1998). 
Assim, por adotarem critérios metodológicos bem definidos, as revisões sistemáticas podem ser consideradas um processo científico, na medida em que seus resultados podem ser reproduzidos por outros pesquisadores. As revisões tradicionais, por outro lado, incluem evidências científicas selecionadas de modo parcial e limitadas ao conhecimento do pesquisador, caracterizando-se assim como um método subjetivo e informal de pesquisa (KLASSEN e col., 1998).

Embora as revisões sistemáticas que analisam efeitos de intervenções em saúde mais comumente incluam os ensaios clínicos aleatorizados controlados, considerados como referência para esse tipo de avaliação, na sua ausência poderiam ser encontradas estimativas de efeitos a partir de estudos com outros desenhos, como por exemplos os de coorte e caso-controle, desde que bem delineados (EGGER e col., 2006).

Dentre as etapas empregadas na condução de revisões sistemáticas de literatura, destaca-se a análise da qualidade metodológica dos estudos a serem incluídos, uma vez que a relevância dos resultados para a tomada de decisões em saúde dependerá da qualidade dos estudos nela incluídos (JADAD e col., 1998; MALLEN e col., 2006). Portanto, a inclusão de estudos com baixa qualidade metodológica pode acarretar em vieses nos resultados das revisões sistemáticas, comprometendo assim suas conclusões (JADAD e col., 1998; BERLIN e RENNIE, 1999; JÜNI e col., 2001; STERNE e col., 2001).

\subsection{JUSTIFICATIVA}

Embora a deficiência de selênio seja rara e somente observada em áreas onde o solo é pobre neste mineral, estudos sugerem que o baixo estado nutricional do mineral possa relacionar-se à ocorrência de diversos desfechos gestacionais adversos, incluindo abortos, defeitos do tudo neural, 
partos pré-termo, baixo peso ao nascer, restrição de crescimento intrauterino, pré-eclampsia e diabetes gestacional. Uma vez considerados os principais papéis fisiológicos do selênio, é possível que ele tenha um papel crítico no sistema imunológico materno e em sua função tireoidiana.

Deste modo, pode-se levantar a hipótese de que gestantes poderiam ser beneficiadas com um aumento em sua ingestão habitual do mineral ou ainda com sua suplementação, independentemente de serem deficientes ou não, o que poderia refletir em uma redução da morbidade e mortalidade tanto maternas quanto da criança, com melhoras significativas em seu estado geral de saúde. É preciso então estabelecer os reais benefícios dessa intervenção, com base em evidências de qualidade, além de investigar seus possíveis efeitos adversos, justificando-se assim a necessidade de condução de uma revisão sistemática de literatura. 


\section{OBJETIVOS}

\subsection{OBJETIVO GERAL}

Avaliar os efeitos da suplementação de selênio durante a gestação no que se refere às condições de saúde da mulher e do recém-nascido, por meio de uma revisão sistemática de literatura.

\subsection{OBJETIVOS ESPECÍFICOS}

Avaliar os efeitos da suplementação de selênio durante a gestação no que diz respeito a:

> Morbidade materna e neonatal e sintomas de doenças;

> Mortalidade materna e neonatal;

> Desfechos gestacionais adversos;

> Peso ao nascer e escore de APGAR do recém-nascido

> Ganho de peso gestacional;

$>$ Satisfação materna;

> Efeitos colaterais da suplementação;

> Estado nutricional relativo ao selênio materno e do recém-nascido;

> Estresse oxidativo materno e do recém-nascido;

$>$ Composição do leite materno. 


\section{MÉTODOS}

O presente estudo trata-se de uma revisão sistemática de literatura, para a qual foram adotados os passos metodológicos descritos a seguir.

\subsection{PERGUNTA DE PESQUISA}

Estabeleceu-se como pergunta de pesquisa: "Quais os efeitos da suplementação de selênio realizada durante a gestação sobre as condições de saúde da mãe e do recém-nascido, comparada à administração de placebo ou nenhuma intervenção?". Esta pergunta de pesquisa, que investiga os efeitos de uma intervenção, foi construída com base no mnemônico PICO (P: population - população, I: intervention intervenção, C: comparison - comparação e O: outcome - desfecho) (JOANNA BRIGGS INSTITUTE, 2008), cujos aspectos de interesse estão apresentados detalhadamente no item 3.2.

\subsection{CRITÉRIOS DE INCLUSÃO DE ESTUDOS NO LEVANTAMENTO INICIAL}

Os critérios de inclusão dizem respeito à população, à intervenção, à comparação, desfechos e desenhos metodológicos de interesse.

\subsubsection{População de Interesse}

Consideraram-se mulheres gestantes, em qualquer faixa etária, independentemente de suas condições de saúde e nutricional, da presença 
de complicações gestacionais, de suplementação anterior à gravidez e da presença de tratamentos medicamentosos.

\subsubsection{Intervenção de Interesse}

Suplementação nutricional com selênio recebida na forma medicamentosa ou dietética durante a gestação, independentemente do período gestacional, da dosagem e do tipo de composto mineral utilizado.

Não foram considerados estudos que utilizassem o selênio associado a outros micronutrientes, visto que há uma revisão sistemática publicada que avalia o efeito da suplementação de múltiplos micronutrientes para gestantes (HAIDER e BHUTTA, 2006).

\subsubsection{Comparação de Interesse}

Foram considerados estudos que avaliassem os efeitos da suplementação de selênio em relação a qualquer grupo de comparação que fizesse uso de placebo ou que não recebesse nenhum tipo de intervenção.

\subsubsection{Desfechos de Interesse}

\section{Relacionados à gestante/parturiente}

\section{Desfechos Primários}

> Ocorrência de morbidade materna (infecções, estados inflamatórios, mastite, disfunção tireoidiana, pré-eclampsia, eclampsia, diabetes tipo 2);

> Ocorrência de desfechos gestacionais adversos (abortos espontâneos, mortes fetais, ruptura prematura de membrana, partos pré-termo);

$>$ Mortalidade materna;

> Ocorrência de sintomas de doenças (febre, náusea e êmese); 


\section{Desfechos Secundários}

$>$ Ganho de peso gestacional;

> Satisfação materna;

$>$ Ocorrência de efeitos colaterais da suplementação

$>$ Estado nutricional relativo ao selênio (concentrações plasmáticas e sangüíneas de selênio, concentrações de selênio na urina, unhas e cabelos, atividade plasmática de glutationa peroxidase);

> Concentrações de selênio e atividade de glutationa peroxidase no leite materno;

$>$ Composição do leite materno.

\section{Relacionados ao recém-nascido}

\section{Desfechos primários}

$>$ Ocorrência de morbidade neonatal (<28 dias de vida) (infecções, estados inflamatórios, defeitos do tubo neural, diarréia);

> Mortalidade do recém-nascido (<28 dias de vida);

$>$ Ocorrência de sintomas de doenças (febre, náusea e êmese);

$>$ Peso ao nascer.

\section{Desfechos secundários}

$>$ Ocorrência de efeitos colaterais da suplementação;

$>$ Estado nutricional relativo ao selênio (concentrações plasmáticas e sangüíneas de selênio, concentrações de selênio na urina, unhas e cabelos, atividade plasmática de glutationa peroxidase);

$>$ Escore de APGAR.

\subsubsection{Desenhos Metodológicos de Interesse}

Apesar de grande parte das revisões sistemáticas referentes ao efeito de intervenções se restringirem a ensaios clínicos aleatorizados controlados (RCTs, do inglês randomised controlled clinical trials), nesta revisão optou-se 
por incluir estudos com outros tipos de desenho metodológico como, por exemplo, ensaios clínicos não aleatorizados, estudos de coorte ou casocontrole, desde que avaliassem os efeitos da administração de suplementos de selênio durante a gestação sobre os desfechos de interesse.

Resumem-se no Quadro 3 os principais aspectos de interesse para a seleção inicial dos estudos desta revisão sistemática.

Quadro 3 - Aspectos de interesse para a seleção inicial dos estudos desta revisão sistemática.

\begin{tabular}{|l|l|}
\hline População & $\begin{array}{l}\text { Gestantes, saudáveis ou não saudáveis, em qualquer faixa etária, } \\
\text { independentemente de seu estado nutricional. }\end{array}$ \\
\hline Intervenção & $\begin{array}{l}\text { Suplementação de selênio (isolado), realizada durante o período } \\
\text { gestacional. }\end{array}$ \\
\hline Comparação & $\begin{array}{l}\text { Qualquer tipo de grupo de comparação, desde que recebendo placebo } \\
\text { ou nenhuma intervenção. }\end{array}$ \\
\hline Desfechos & $\begin{array}{l}\text { Variáveis-resposta relacionadas às condições de saúde da mãe e do } \\
\text { recém-nascido. } \\
\text { Ensaios clínicos aleatorizados controlados, ensaios clínicos não } \\
\text { aleatorizados, estudos de coorte e estudos caso-controle. }\end{array}$ \\
\hline
\end{tabular}

\subsection{ESTRATÉGIAS PARA A IDENTIFICAÇÃO DE ESTUDOS}

Realizou-se a identificação das bases de dados, a definição das palavras-chave, a construção das sentenças de busca e a realização da busca propriamente dita.

Selecionaram-se para as buscas as seguintes bases de dados bibliográficas:

CINAHL with Full Text: mais abrangente base de dados de textos completos na área de enfermagem e de saúde, com acesso a artigos completos de cerca de 600 periódicos. Apresenta cobertura de registros 
desde 1981. Oferece também acesso a livros e capítulos de livros, dissertações da área de enfermagem, resumos publicados em anais de eventos, entre outros materiais. Acesso pelo portal de periódicos CAPES.

Current Contents Connect: incluída na base ISI Web of Knowledge, apresenta informações de periódicos, livros, documentos e sítios de internet avaliados. Nas categorias "Ciências da agricultura, biológicas e ambientais" e "Ciências da vida" compreende trabalhos publicados desde 1998. Acesso pelo SibiNet.

EMBASE: base de dados de resumos e indexação, especializada na área biomédica, sobressaindo-se especialmente em pesquisas farmacêuticas. Faz parte da Elsevier, editor de informações científicas, técnicas e médicas de grande destaque mundial. Acesso pelo SibiNet.

Evidence-Based Medicine Reviews (EBM Reviews): base de dados eletrônica que combina sete fontes distintas para fornecer informações sobre medicina baseada em evidências. Fornece revisões sistemáticas, análises de artigos publicados, e acesso a ensaios clínicos controlados. Abrange as seguintes bases: Cochrane Database of Systematic Reviews, ACP Journal Club, Database of Abstracts of Reviews of Effect, Cochrane Central Register of Controlled Trials, Cochrane Methodology Register, Health Technology Assessment e NHS Economic Evaluation Database. Acesso pelo SibiNet.

Food Science and Tech Abstracts: coleção de resumos sobre ciência e tecnologia de alimentos e nutrição humana relacionada a produtos alimentares. Contém mais de 775 mil registros provenientes de mais de 90 países e 40 línguas datados desde 1969, cobrindo publicações, patentes, relatórios, revisões, normas, teses, legislação, procedimentos de conferência e livros de fontes industriais e acadêmicas. Acesso pelo SibiNet. 
LILACS: produto da Biblioteca Virtual em Saúde, é um índice bibliográfico de literatura em ciências da saúde publicado a partir de 1982 em países da América Latina e do Caribe. Em 2009, atingiu a marca de 500.000 mil registros bibliográficos de artigos publicados em cerca de 1.500 periódicos da área da saúde, dos quais aproximadamente 800 são atualmente indexados. Indexa ainda outros tipos de literatura científica e técnica incluindo teses, monografias, livros e capítulos de livros, trabalhos apresentados em congressos ou conferências, relatórios, publicações governamentais e de organismos internacionais regionais. Acesso pelo Portal da Biblioteca Virtual em Saúde (BVS).

ProQuest - Dissertations and Theses: oferece acesso a uma infinidade de bases, dentre as quais uma base interdisciplinar de Dissertações e Teses, permitindo a busca por estudos não publicados. Acesso pelo SibiNet.

PubMed / MEDLINE: O Pubmed, fonte de acesso livre desenvolvida e mantida pelo Centro Nacional de Informação em Biotecnologia (National Center for Biotechnology Information - NCBI) na Biblioteca Nacional de Medicina dos Estados Unidos (National Library of Medicine - NLM), permite buscas em milhões de periódicos e resumos nas áreas de medicina, enfermagem, odontologia, medicina veterinária, sistemas de saúde e ciências pré-clínicas publicados nos Estados Unidos e em mais de 70 países. Inclui tanto acesso ao Medline quanto a citações de artigos em periódicos de ciências da vida não cobertos por esta base. Contém referências de artigos publicados desde 1966. Acesso livre pelo site www.pubmed.com.

Science Direct: base de dados científica que oferece artigos de mais de 2.500 periódicos revisados por pares. Encontram-se digitalizados nessa base muitos artigos anteriores a 1995, podendo ser encontrados trabalhos que datam desde 1823. Assim como a EMBASE, também é parte da Elsevier. Acesso pelo SibiNet. 
SCOPUS: maior base de dados de citações e literatura científica. Oferece acesso a aproximadamente 18 mil periódicos revisados por pares de mais de cinco mil editoras, incluindo resumos de trabalhos apresentados em eventos científicos e artigos no prelo de mais de 3 mil periódicos. Sua cobertura inclui literatura científica e técnica de ciências da saúde, da vida, sociais e humanas. Mais da metade de seu conteúdo é originada na Europa, América Latina e da região do pacífico na Ásia. Inclui arquivos datados desde 1823. Acesso pelo SibiNet.

Web of Science: assim como a Current Contents Connect, está inserida na base ISI Web of Knowledge. Inclui literatura em diversas áreas, dentre elas a de ciências, e resumos de trabalhos científicos apresentados em conferências, simpósios, seminários, colóquios, workshops e convenções internacionais. Compreende trabalhos publicados na área de ciências desde 1900 e resumos científicos desde 1991. Acesso pelo SibiNet.

Para a definição inicial das palavras-chave foi conduzida uma busca limitada no MEDLINE e em artigos sobre o tema de interesse para avaliar as palavras contidas nos títulos e resumos, bem como os termos de indexação utilizados na descrição dos artigos. Na lista preliminar, foram incluídas palavras-chave baseadas na população (pregnancy, pregnant women, gestation) e na intervenção de interesse (selenium, selenium-compounds, selenomethionine, selenate, selenite, supplementation, supplements). Considerando-se o interesse em incluir nesta revisão qualquer tipo de desenho de estudo, decidiu-se por não utilizar palavras-chave relativas ao delineamento.

Os levantamentos nas bases de dados foram conduzidos utilizandose frases construídas a partir das palavras-chaves e de operadores booleanos (ex. AND, OR e NOT), que permitiram ampliar ou restringir o número de estudos identificados. As palavras-chave inicialmente selecionadas poderiam ser substituídas, ampliadas ou restringidas de acordo com as características próprias de cada base. 
Incluíram-se nesta revisão estudos em inglês, português e espanhol, publicados até agosto de 2009. A busca dos trabalhos foi feita de tal forma que tornasse o processo reprodutível, sendo registradas informações como a base de dados, a data da busca, a frase e o número de trabalhos encontrados. Ao final das buscas, as referências e resumos encontrados foram armazenados em banco de dados no programa gerenciador de referências bibliográficas EndNote 7.0 para Windows para exclusão das réplicas e organização dos resumos para a fase de elegibilidade.

\subsection{COLETA E ANÁLISE DE DADOS}

\subsubsection{Seleção dos Estudos}

A seleção inicial dos estudos foi conduzida com base na população, no tipo de intervenção, na comparação de intervenção, nos desfechos e delineamentos de interesse (item 3.2).

Os resumos dos trabalhos identificados $\left(\mathrm{N}_{0}\right)$ foram lidos e analisados de modo independente por três avaliadores, que decidiram sobre sua elegibilidade a partir do preenchimento de um instrumento que incluía as principais características de interesse (Apêndice 1). Decidiu-se que os trabalhos que não apresentassem resumos seriam lidos na íntegra e que naqueles casos em que os resumos que não fossem claros o suficiente para a tomada de decisão quanto à inclusão, os métodos do trabalho seriam lidos. Os artigos para os quais os avaliadores apresentaram opinião discordante foram discutidos e a decisão final se deu por consenso.

Foram conferidas ainda as listas de referências dos estudos selecionados para a identificação de possíveis trabalhos relevantes que não tivessem sido encontrados por meio da busca eletrônica. 


\subsubsection{Análise de Qualidade}

Após a leitura dos resumos, os estudos eleitos foram lidos na íntegra para a avaliação da qualidade metodológica $\left(\mathrm{N}_{1}\right.$, Figura 1$)$.

Para esta etapa, utilizaram-se instrumentos adequados a cada tipo de desenho. Os ensaios clínicos foram avaliados com base nos métodos descritos no Cochrane's Reviewer's Handbook (HIGGINS e GREEN, 2008) (Anexo 1). Primeiramente, foram avaliados com relação ao risco de vieses, que incluía a presença de viés de seleção (aleatorização), viés de desempenho (sigilo de alocação), viés de seguimento e viés de detecção, sendo então classificados conforme apresentado no Quadro 4.

Quadro 4 - Classificação dos ensaios clínicos aleatorizados segundo risco de vieses.

\begin{tabular}{|l|l|l|}
\hline Risco de Vieses & \multicolumn{3}{|c|}{ Interpretação } & \multicolumn{1}{c|}{$\begin{array}{c}\text { Relação com os critérios } \\
\text { individuais }\end{array}$} \\
\hline A) Baixo & $\begin{array}{l}\text { Apresenta vieses que muito } \\
\text { provavelmente não provocam } \\
\text { grandes alterações nos resultados }\end{array}$ & Todos os critérios são cumpridos. \\
\hline B) Moderado & $\begin{array}{l}\text { Apresenta vieses que levantam } \\
\text { algumas dúvidas sobre os } \\
\text { resultados. }\end{array}$ & $\begin{array}{l}\text { Um ou mais critérios são } \\
\text { parcialmente cumpridos }\end{array}$ \\
\hline C) Elevado & $\begin{array}{l}\text { Apresenta vieses que } \\
\text { comprometem seriamente os } \\
\text { resultados. }\end{array}$ & $\begin{array}{l}\text { Um ou mais critérios não são } \\
\text { cumpridos }\end{array}$ \\
\hline
\end{tabular}

Fonte: adaptado de HIGGINS e GREEN, 2005.

Em seguida, avaliaram-se os estudos de acordo com a adequação do sigilo de alocação, segundo explicitado no Quadro 5. 
Quadro 5 - Classificação dos ensaios clínicos aleatorizados segundo o sigilo de alocação.

\begin{tabular}{|l|l|}
\hline \multicolumn{1}{|c|}{ Sigilo de Alocação } & \multicolumn{1}{|c|}{ Descrição } \\
\hline \multirow{2}{*}{ A) Adequado } & $\begin{array}{l}\text { Aleatorização centralizada; administração seqüencial de } \\
\text { envelopes/pacotes pré-codificados ou numerados; dados } \\
\text { gerados por um programa de computador; pessoa responsável } \\
\text { pelo sorteio não envolvida diretamente na alocação do } \\
\text { paciente. }\end{array}$ \\
\hline B) Não claro & $\begin{array}{l}\text { Não há menção sobre a alocação utilizada ou há suspeita de } \\
\text { falha. }\end{array}$ \\
\hline C) Inadequado & $\begin{array}{l}\text { Alternância; utilização de número de prontuários, datas de } \\
\text { nascimento, dias da semana ou qualquer outro processo não } \\
\text { sigiloso (lista aberta de números aleatórios). }\end{array}$ \\
\hline D) Não utilizado & Não houve sigilo de alocação dos participantes nos grupos. \\
\hline
\end{tabular}
Fonte: adaptado de HIGGINS e GREEN, 2005.

Adicionalmente, optou-se por avaliar os estudos por meio do instrumento proposto por DOWNS e BLACK (1998), que considera o rigor metodológico tanto de estudos aleatorizados quanto de estudos não aleatorizados (Anexo 2). A ferramenta considera itens relativos ao reporting, à validade externa, à validade interna (vieses e fatores de confusão) e ao poder do estudo. Permite, a partir do preenchimento de um formulário, que se atribua a cada artigo um total de até 32 pontos segundo suas características metodológicas. Nesta revisão, estabeleceu-se que somente seriam incluídos artigos com pontuação igual ou superior a 16 (50\% do total de pontos atribuíveis).

A análise de qualidade dos trabalhos eleitos foi realizada por dois avaliadores, sendo as opiniões discordantes quanto à inclusão ou não dos estudos decididas por consenso.

\subsubsection{Extração de Dados}

Os estudos com qualidade metodológica foram considerados para a etapa de extração de dados. O processo de seleção dos estudos, desde a localização dos resumos até a presente etapa, está apresentado esquematicamente na Figura 1. 


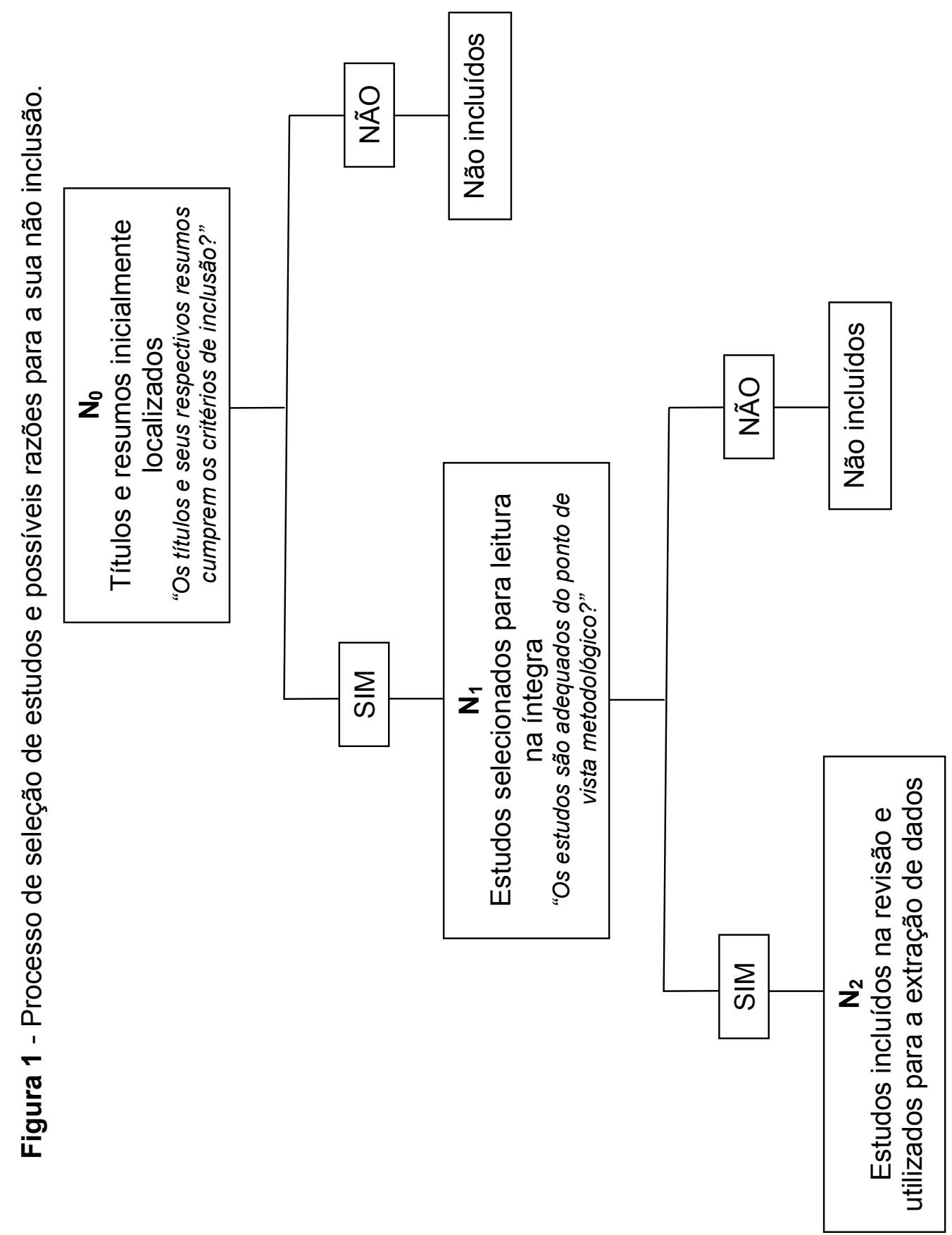


A extração de dados foi conduzida por um avaliador, sendo posteriormente conferida por um segundo avaliador. Além dos dados relativos aos desfechos de interesse, foram extraídas informações relativas às características dos trabalhos no que se refere à população estudada, ao tamanho da amostra, à composição, dose e frequência de administração do suplemento, ao início e tempo total do tratamento, bem como ao desenho do estudo e ao local onde o mesmo foi conduzido.

\subsubsection{Síntese e Análise dos Dados}

As principais características dos estudos incluídos e não incluídos, compreendendo dados referentes à autoria, publicação, população, intervenção, comparação de intervenção e desfechos de interesse foram apresentadas em quadros e de forma narrativa. Apresentaram-se ainda os motivos para não inclusão dos estudos não selecionados para a revisão.

Somente dois dos desfechos de interesse foram avaliados por mais de um estudo (concentrações plasmáticas de selênio maternas e concentrações de selênio no leite materno). Contudo, não foi possível realizar agrupamento estatístico das variáveis-resposta (metanálise), devido à presença de diferenças metodológicas entre os estudos, que incluíam diferentes doses suplementadas e períodos de início da intervenção. Por estas razões, os resultados dos estudos foram também descritos de forma narrativa, tal qual apresentados pelos autores dos originais (médias \pm desvios-padrão e porcentagens).

\subsubsection{Contatos com Autores}

Foram realizados contatos por email com os autores correspondentes de três trabalhos incluídos (NEGRO e col. 2007; DODGE e col., 1999; THOMSON e col., 2001), com o objetivo de esclarecer algumas dúvidas com relação à metodologia ou aos resultados dos trabalhos. Em email enviado a Rosemary Wander (DODGE e col., 1999), questionou-se acerca de dados 
que foram apresentados de forma um pouco confusa, não havendo concordância entre os relatos e valores do texto e o título e valores apresentados em uma das figuras. No contato com Christine Thomson (THOMSON e col., 2001), indagou-se a respeito de algumas informações que faltavam em uma das tabelas do artigo. Em mensagem enviada a Robert Negro (NEGRO e col., 2007), buscou-se esclarecer o período de intervenção. Somente não se obteve resposta para o contato com Rosemary Wander.

\subsubsection{Conflitos de Interesse}

Este estudo não recebeu nenhum tipo de financiamento externo. Os autores declaram a inexistência de conflitos de interesse. 


\section{RESULTADOS}

\subsection{BUSCA E SELEÇÃO DOS ESTUDOS}

Identificaram-se, a partir das buscas nas bases de dados, 123 trabalhos, tendo sido a maior proporção encontrada na base Web of Science $(35,8 \%, \mathrm{n}=44)$, seguida pelas bases Current Contens Connect $(25,2 \%$, $\mathrm{n}=31)$, EBM Reviews (12,2\%, $\mathrm{n}=15)$, Pubmed/Medline $(8,9 \%, \mathrm{n}=11)$, CINAHL $(8,1 \%, \mathrm{n}=10)$, EMBASE $(5,7 \%, \mathrm{n}=7)$ e Science Direct $(4,1 \%, \mathrm{n}=5)$ (Figura 2). Nas bases Scopus, Food Science and Technology Abstracts, LILACS e Pro Quest não foi identificado nenhum trabalho (Apêndice 2).

Figura 2 - Distribuição dos trabalhos encontrados segundo base bibliográfica de dados.

Bases de Bibliográficas de Dados

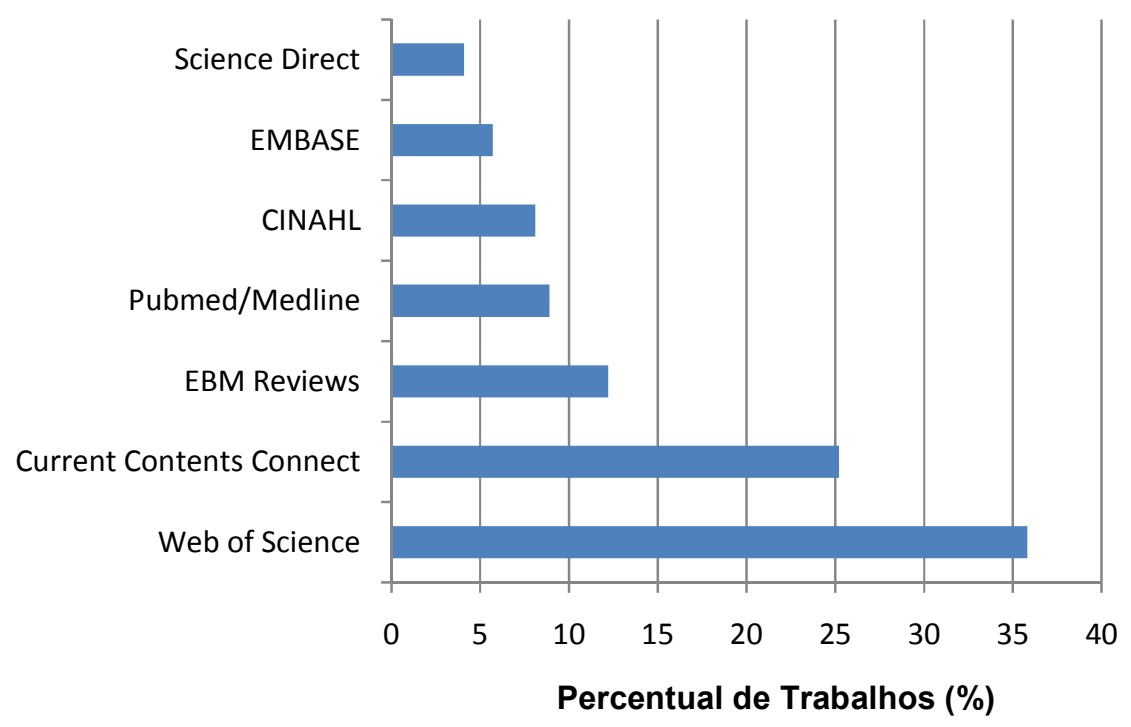


Quando importadas as referências para o programa EndNote ${ }^{\circledR}$, excluíram-se 47 duplicatas, totalizando 76 trabalhos para a leitura dos resumos. A partir da leitura dos resumos por três avaliadores (ABM, DPB e JFA), decidiu-se pela inclusão de 10 trabalhos para leitura na íntegra e avaliação de qualidade. Adicionalmente, decidiu-se pela leitura da sessão relativa aos métodos de dois trabalhos, para os quais não foi possível a tomada de decisão quanto à sua inclusão a partir do resumo (DISON e col., 1993 e SCHRAUZER, 1994). As referências dos trabalhos localizados encontram-se no Apêndice 3.

Após a leitura na íntegra ou dos métodos destes 12 trabalhos, sete não foram submetidos à avaliação de qualidade, por motivos detalhados no Quadro 6.

\subsection{ANÁLISE DE QUALIDADE}

Identificaram-se cinco estudos para a etapa de análise de qualidade, dos quais três eram ensaios clínicos aleatorizados controlados e dois tratavam-se de ensaios clínicos controlados sem aleatorização. Quanto ao risco de vises, apenas um estudo foi considerado com "baixo risco" e com sigilo de alocação "adequado" segundo o modelo da Cochrane (NEGRO e col., 2007) e foi o que apresentou a maior pontuação de acordo com a ferramenta proposta por DOWNS e BLACK (1998). Três outros estudos apresentaram "risco moderado" de vieses, dos quais um não utilizou sigilo de alocação e dois não descreveram o método de alocação, sendo então classificados como "não claro" (Quadro 7). 
Quadro 6 - Características dos estudos não incluídos na etapa de análise de qualidade e principais motivos.

\begin{tabular}{|c|c|c|}
\hline $\begin{array}{l}\text { Referência } \\
\text { (Autor, Ano) }\end{array}$ & Características dos estudos & Motivos para a não inclusão \\
\hline BRO e col., 1988 & $\begin{array}{l}\text { Estudo transversal que avaliou as } \\
\text { concentrações de selênio maternas e no } \\
\text { cordão umbilical de mulheres } \\
\text { dinamarquesas no momento do parto. }\end{array}$ & $\begin{array}{l}\text { Não avalia suplementação com } \\
\text { selênio isoladamente. }\end{array}$ \\
\hline DISON e col., 1993 & $\begin{array}{l}\text { Estudo transversal que mensurou } \\
\text { concentrações plasmáticas de retinol, alfa- } \\
\text { tocoferol, colesterol total, selênio e a } \\
\text { atividade de glutationa peroxidase no } \\
\text { sangue venoso materno, no sangue do } \\
\text { cordão umbilical e em amostras de sangue } \\
\text { capilar de recém-nascidos. }\end{array}$ & $\begin{array}{l}\text { Nenhum grupo de gestantes } \\
\text { utilizou rotineiramente suplemento } \\
\text { com selênio isolado. }\end{array}$ \\
\hline $\begin{array}{l}\text { KUPKA e col., } \\
\qquad 2008\end{array}$ & $\begin{array}{l}\text { Ensaio clínico aleatorizado controlado que } \\
\text { avaliou os efeitos da suplementação com } \\
200 \mu \mathrm{g} \text { de selênio na forma de } \\
\text { selenometionina em gestantes infectadas } \\
\text { pelo HIV residentes em Dar Es Salaam, } \\
\text { Tanzânia, sobre desfechos de saúde } \\
\text { relativos à mãe e ao recém-nascido. }\end{array}$ & $\begin{array}{l}\text { Foi utilizada suplementação com } \\
\text { multivitamínicos. }\end{array}$ \\
\hline $\begin{array}{l}\text { KUPKA e col., } \\
\qquad 2009\end{array}$ & $\begin{array}{l}\text { Ensaio clínico aleatorizado controlado que } \\
\text { avaliou os efeitos da suplementação com } \\
200 \mu \mathrm{g} \text { de selênio na forma de } \\
\text { selenometionina sobre as concentrações } \\
\text { de hemoglobina e a ocorrência de } \\
\text { morbidade em gestantes infectadas pelo } \\
\text { HIV residentes em Dar Es Salaam, } \\
\text { Tanzânia. }\end{array}$ & $\begin{array}{l}\text { Foi utilizada suplementação com } \\
\text { multivitamínicos. }\end{array}$ \\
\hline LI e col., 2009 & $\begin{array}{l}\text { Ensaio clínico aleatorizado controlado que } \\
\text { avaliou a suplementação com múltiplos } \\
\text { micronutrientes em gestantes de regiões } \\
\text { rurais da China. }\end{array}$ & $\begin{array}{l}\text { Foi realizada suplementação com } \\
\text { múltiplos micronutrientes. }\end{array}$ \\
\hline $\begin{array}{l}\text { LOMBECK e col., } \\
\qquad 2009\end{array}$ & $\begin{array}{l}\text { Estudo transversal que avaliou o estado de } \\
\text { selênio de } 29 \text { mulheres com fenilcetonúria } \\
\text { do German Collaborative Study of } \\
\text { Phenylketonuria. }\end{array}$ & $\begin{array}{l}\text { Não houve intervenção com } \\
\text { suplemento de selênio. }\end{array}$ \\
\hline $\begin{array}{l}\text { SCHRAUZER e } \\
\text { col., } 1994\end{array}$ & $\begin{array}{l}\text { Estudo de revisão acerca do papel do } \\
\text { selênio na manutenção e terapia de } \\
\text { indivíduos infectados pelo vírus HIV. }\end{array}$ & Artigo de revisão. \\
\hline
\end{tabular}


Quadro 7 - Resultados referentes à avaliação da qualidade metodológica dos estudos.

\begin{tabular}{|c|c|c|c|c|}
\hline \multirow[b]{2}{*}{$\mathbf{N}^{\circ}$} & \multirow[b]{2}{*}{$\begin{array}{l}\text { Referência } \\
\text { (Autor, Ano) }\end{array}$} & \multicolumn{2}{|c|}{ Cochrane Collaboration } & \multirow{2}{*}{$\begin{array}{c}\text { Escore de } \\
\text { Downs \& } \\
\text { Black }\end{array}$} \\
\hline & & $\begin{array}{c}\text { Risco de } \\
\text { Vieses }\end{array}$ & $\begin{array}{l}\text { Sigilo de } \\
\text { Alocação }\end{array}$ & \\
\hline 1 & NEGRO e col., 2007 & Baixo & Adequado & 25 \\
\hline 2 & MOORE e col., 2000 & Moderado & Não claro & 24 \\
\hline 3 & DODGE e col., 1999 & Moderado & Não claro & 21 \\
\hline 4 & THOMSON e col., 2001 & Moderado & Não utilizado & 19 \\
\hline 5 & HAN e ZHOU, 1994 & Elevado & Não claro & 14 \\
\hline
\end{tabular}

O único estudo considerado de baixa qualidade metodológica e, portanto, não incluído nesta revisão, foi o conduzido por HAN e ZHOU (1994). Este apresentou limitações que incluem: apesar de se tratar de um ensaio clínico aleatorizado controlado, não foi relatada a forma de aleatorização das participantes ou se houve sigilo de alocação; não houve descrição da população de estudo e dos critérios para sua seleção; embora os autores refiram a presença de fatores de risco para a hipertensão induzida pela gestação, tais fatores não são explicitamente mencionados; não há detalhamento sobre a intervenção, incluindo o seu período de início e sua duração; não foram descritas as formas pelas quais as principais variáveis-desfecho foram mensuradas.

Foram então incluídos nesta revisão sistemática os estudos $n^{\circ} 1,2,3$ e 4 (Quadro 7). Os resultados da busca, seleção e análise de qualidade dos estudos desta revisão sistemática são esquematicamente apresentados na Figura 3. 
Figura 3 - Fluxograma dos resultados da busca, seleção e análise de qualidade dos estudos.

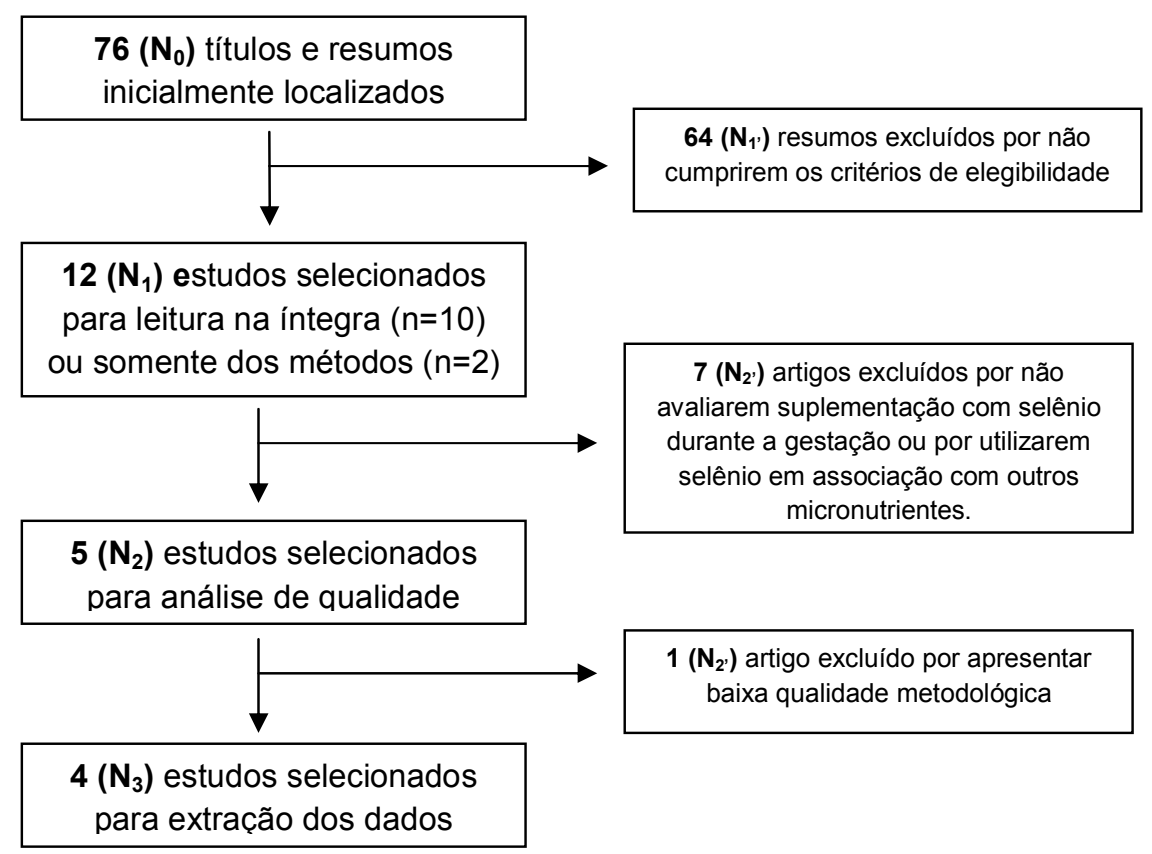

\subsection{CARACTERÍSTICAS METODOLÓGICAS DOS ESTUDOS INCLUÍDOS}

Apresentam-se a seguir as características metodológicas dos estudos incluídos nesta revisão sistemática, que também estão detalhadas nos Quadro 8 (desenho, população de estudo e intervenção) e no Quadro 9 (desfechos de avaliados, procedimentos analíticos e testes estatísticos empregados na análise dos resultados).

DODGE e col. (1999)

Ensaio clínico aleatorizado controlado cego para os participantes (single-blind) que teve como objetivo avaliar os efeitos da suplementação de selênio na concentração de ácidos graxos do leite materno em lactantes. 
As participantes eram mulheres saudáveis, com idades entre 20 e 30 anos, no primeiro ou segundo mês de gestação, residentes em Dunedin, Nova Zelândia, e que faziam parte de um estudo maior desenvolvido para investigar a influência da gestação e da lactação no metabolismo de selênio em mulheres normais, saudáveis, porém com baixo estado nutricional relativo ao mineral.

A intervenção compreendeu a suplementação com tabletes que continham $50 \mu \mathrm{g}$ de selênio/dia na forma de selenometionina, administrada durante a gestação e a lactação. O momento de início da suplementação não foi informado.

As participantes foram orientadas a manter a alimentação habitual e tiveram seu consumo alimentar avaliado em dois momentos (gestação e lactação), a partir da aplicação de um questionário de frequência alimentar utilizado rotineiramente no Departamento de Nutrição Humana da Universidade de Otago, Dunedin.

Os desfechos avaliados foram as concentrações de selênio e ácidos graxos e a atividade de glutationa peroxidase no leite materno, mensurados em dois momentos: de 1 a 7 dias após o parto e três meses depois. Não houve perdas de seguimento.

MOORE e col. (2000)

Estudo de intervenção controlado cego para os participantes (singleblind) cujo objetivo foi avaliar o efeito da suplementação de selênio nas concentrações desse mineral e a atividade de glutationa peroxidase do plasma e do leite materno a longo do tempo, a partir do parto, em mulheres Chinesas com ingestão dietética habitualmente baixa de selênio.

As participantes foram gestantes com idades entre 20 e 30 anos residentes em Xichang, China, região rural onde a ingestão de selênio é considerada baixa. As gestantes foram recrutadas por médicos locais e residiam em vilas da região desde o nascimento, não tinham utilizado suplementos de selênio no ano anterior à gestação, apresentavam-se em 
boas condições de saúde havia pelo menos um ano e tinham condições socioeconômicas e estilos de vida semelhantes.

No grupo tratamento $(n=11)$, as mulheres receberam diariamente dois tabletes contendo fermento de levedura enriquecido com selênio, totalizando $100 \mu \mathrm{g}$ de selênio e no grupo placebo $(n=10)$, receberam tabletes similares contendo apenas a levedura, com $0,63 \mu \mathrm{g}$ de selênio por tablete. A intervenção foi iniciada no início do terceiro trimestre de gravidez, continuando até três meses após o parto.

Foram coletadas amostras de sangue em até seis dias após o nascimento das crianças e na $2^{\mathrm{a}}, 4^{\mathrm{a}}$ e $12^{\mathrm{a}}$ semana após o parto. Amostras de leite materno foram colhidas nos mesmos períodos do sangue e ainda na $1^{\text {a }}$ e na $3^{\mathrm{a}}$ semana após o parto.

O estudo incluiu monitoramento da utilização dos suplementos, que foi realizado pelos médicos locais. Apesar de não ter havido perdas de seguimento, os dados de uma participante do grupo tratamento foram excluídos das análises estatísticas por serem muito menores que os das demais gestantes do grupo indicando, segundo os autores, não adesão à intervenção.

Avaliaram-se como desfechos, todos relativos apenas à gestante: hematócrito e hemoglobina, concentração de selênio e atividade de glutationa peroxidase no plasma e no leite materno, concentração plasmática de a-tocoferol, concentração plasmática de substâncias reativas com ácido tiobarbitúrico (TBARS) e perfil de ácidos graxos no leite materno e no plasma.

$>$ NEGRO e col. (2007)

Ensaio clínico aleatorizado controlado duplo-cego realizado com mulheres brancas grávidas com anticorpos antiperoxidase tireoidiana (TPOAb), recrutadas em sua primeira visita ao Departamento de Obstetrícia e Ginecologia, quando passaram por triagem de hormônio estimulante da tireóide (TSH), tiroxina livre $\left(\mathrm{FT}_{4}\right)$ e TPOAb. O estudo teve como objetivo investigar os efeitos da suplementação de selênio durante a gestação e o 
pós-parto na função tireoidiana e no padrão autoimune da tireóide dessas mulheres ao longo do período de acompanhamento.

Participaram do estudo gestantes com função tireoidiana normal, mas que possuíam os anticorpos antiperoxidase tireoidiana (TPOAb+), divididas em dois grupos: tratamento $(n=85)$, denominado $S 1$, que recebeu doses diárias de $200 \mu \mathrm{g}$ de selenometionina, e placebo $(n=84)$, denominado S0. Selecionou-se ainda um grupo controle $(n=85)$, intitulado de $C$, composto por mulheres pareadas por idade sem os anticorpos antiperoxidase tireoidiana, que também receberam o tratamento. A intervenção teve início a partir da $12^{\mathrm{a}}$ semana de gestação e foi continuada até $012^{\circ}$ mês pós-parto. Recomendou-se às participantes a utilização de sal iodado.

Principal desfecho de interesse, a função tireoidiana foi avaliada na $20^{a}$ e na $30^{a}$ semana de gestação, no parto, e nos meses 1-2, 5, 9 e 12 após o nascimento da criança, por meio dos seguintes testes: concentrações de $\mathrm{TSH}$ e $\mathrm{T}_{4}$ livre e ultrassonografia da tireóide. Do grupo tratamento, 67,5\% realizaram todos os oito testes previstos, $72,7 \%$ sete de oito, $83,1 \%$ seis de oito e todas as 77 participantes realizaram no mínimo cinco testes. Do grupo placebo, $70,3 \%$ realizaram todos os testes, $75,7 \%$ sete de oito, $83,8 \%$ seis de oito, $91,9 \%$ cinco de oito e todas as 74 participantes realizaram pelo menos quatro testes. Do grupo controle, $56,8 \%$ realizaram os oito testes, $70,4 \%$ realizaram sete de oito, $82,7 \%$ realizaram seis de oito, $93,8 \%$ realizaram cinco de oito e todas as 81 participantes realizaram pelo menos quatro dos oito testes (Tabela 1).

As concentrações sanguíneas de selênio foram avaliadas na primeira visita $\left(9,4 \pm 2,7\right.$ semanas de gestação), na $20^{a}$ e na $30^{a}$ semana de gestação, no parto, 6 e 12 meses após o nascimento da criança. No grupo tratamento, $68,8 \%$ realizaram as seis dosagens de selênio, $71,4 \%$ cinco de seis, $83,1 \%$ quatro de seis e todas as 77 participantes realizaram no mínimo três das seis dosagens planejadas. No grupo placebo, $71,6 \%$ realizaram as seis dosagens planejadas, $90,5 \%$ cinco de seis, $85,9 \%$ quatro de seis e todas as 74 participantes realizaram pelo menos três dosagens. No grupo controle, $60,5 \%$ realizaram as seis dosagens, $83,9 \%$ cinco de seis, $90,1 \%$ quatro de 
seis e todas as 81 participantes realizaram pelo menos três dosagens (Tabela 1).

Com relação às perdas de seguimento, no grupo tratamento houve $9,4 \%$ de perdas ( $n=8$, seis por abortos espontâneos e duas por abandono), no grupo placebo houve $11,9 \%$ de perdas $(n=10$, sete por abortos espontâneos e três abandonos por razões pessoais) e no grupo controle houve $4,7 \%$ de perdas $(n=4$, duas por abortos espontâneos e dois abandonos por razões pessoais) (Tabela 1).

Tabela 1 - Resultados relativos à realização dos testes previstos e às perdas de seguimento do estudo de NEGRO e col. (2007).

Grupo Placebo Grupo Tratamento Grupo Controle

\section{Função Tireoidiana \\ (oito testes previstos)}

Oito testes

Sete testes

Seis testes

Cinco testes

Quatro testes

Dosagens sanguíneas de Se

(seis testes previstos)

Seis testes

Cinco testes

Quatro testes

Três testes

Perdas de Seguimento

Abortos

Abandono
(So)

$\%$

(S1)

$\%$

$$
67,5
$$

72,7

83,1

100,0

91,9

100,0

71,6

90,5

85,9

100,0

8,3

3,6
(C)

$\%$

56,8

70,4

82,7

93,8

100,0

60,5

83,9

90,1

100,0

Os desfechos avaliados foram: função tireoidiana durante a gestação, após o parto e nos 12 meses após o parto, concentrações sanguíneas de selênio maternas, ocorrência de complicações obstétricas (hipertensão, préeclampsia, descolamento prematuro de placenta, partos prematuros) e 
características clínicas dos recém-nascidos (peso, comprimento, perímetro cefálico e escore de APGAR).

\section{THOMSON e col. (2001)}

Ensaio clínico aleatorizado controlado duplo-cego que teve como objetivo investigar a influência da gestação e lactação no metabolismo do selênio em mulheres com baixo estado nutricional deste mineral. Os autores monitoraram ainda o estado de iodo, investigando o efeito da gestação sobre seu metabolismo e a interrelação entre a excreção urinária de iodo e de selênio.

Recrutaram-se mulheres nos estágios iniciais de gestação em Dunedin, Nova Zelândia, dividindo-as em dois grupos: tratamento (Preg+Se, $\mathrm{n}=18$ ), que recebeu diariamente tabletes com $50 \mu \mathrm{g}$ de selênio na forma de L-selenometionina, e placebo (Preg-Se, $n=17$ ), que também recebeu tabletes diariamente, porém sem selênio. A intervenção foi iniciada no $2^{\circ}$ mês de gestação. Foram ainda selecionadas mulheres não gestantes, que receberam a suplementação durante o mesmo período e foram utilizadas como controles positivos (NonPreg+Se, $n=17$ ).

Amostras de sangue e urina foram coletadas em onze momentos, do $2^{\circ}$ ao $9^{\circ}$ mês de gestação e aos 3, 6 e 12 meses pós-parto. As mulheres que serviram como controles positivos também realizaram a coleta desses materiais, em períodos similares às gestantes. Não houve perdas de seguimento, no entanto, no $9^{\circ}$ mês não foi possível coletar dados de $50 \%$ das gestantes que receberam suplementação e de $41 \%$ das gestantes não suplementadas devido ao nascimento anterior à data da coleta. Foram avaliados os seguintes desfechos, todos relativos às mulheres: concentrações plasmáticas de selênio e atividade plasmática de glutationa peroxidase, excreção urinária de selênio e iodo, razão selênio/creatinina e clearance renal de selênio. 


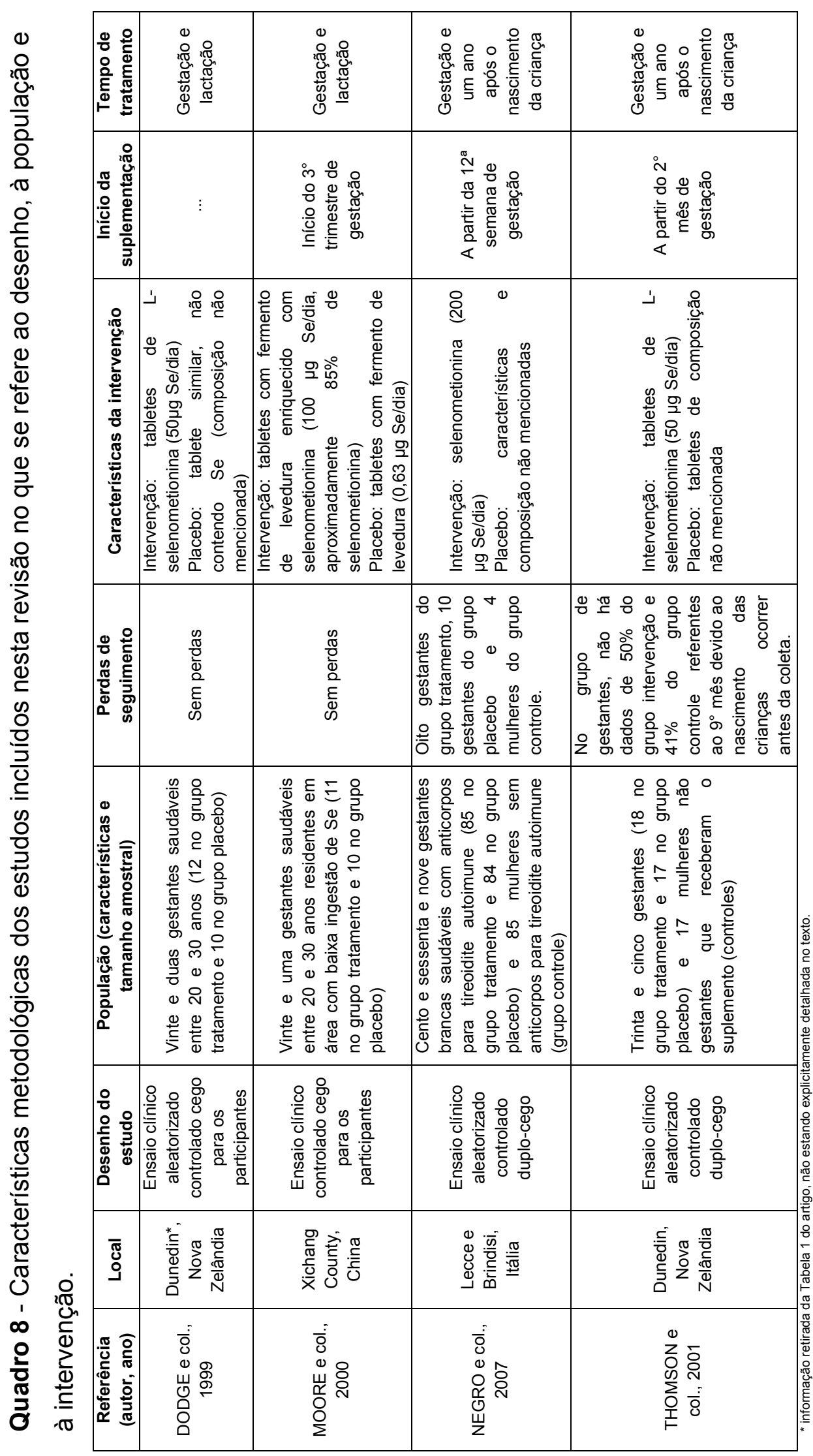




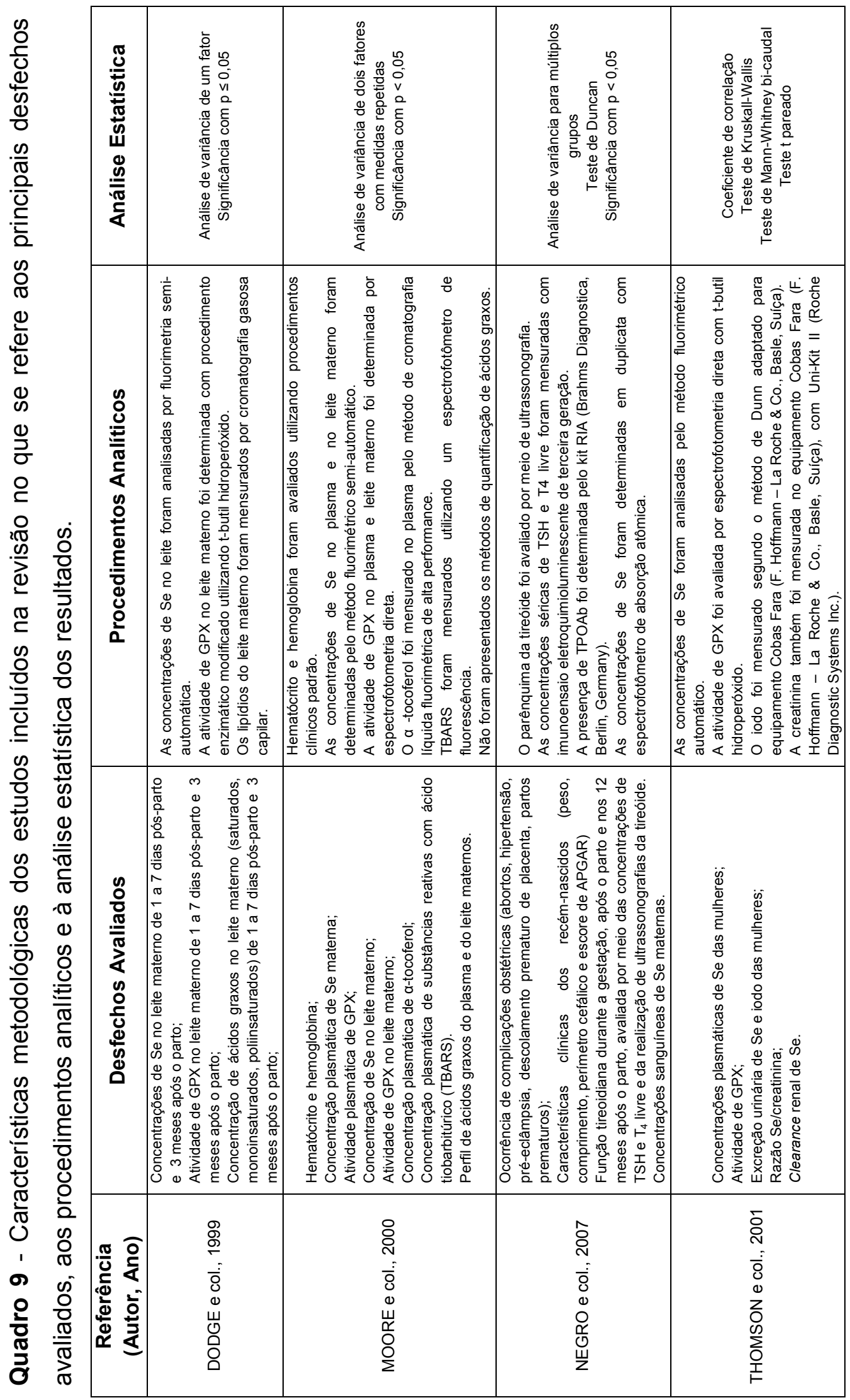




\subsection{CARACTERÍSTICAS DAS POPULAÇÕES DE ESTUDO}

D DODGE e col. (1999)

No início da intervenção os grupos tratamento $(n=12)$ e placebo $(n=10)$ eram semelhantes, com dados resumidos pela média \pm desviopadrão, respectivamente, no que diz respeito à idade $(28,8 \pm 4,0$ e $27,7 \pm 4,4$ anos), gestações anteriores (2,2 $\pm 2,3$ e 1,3 $\pm 1,3)$, anos de residência em Dunedin $(13,5 \pm 11,5$ e $15,4 \pm 11,7$ anos), estatura $(1,7 \pm 0,07$ e 1,6 $\pm 0,04 \mathrm{~m})$, peso materno no momento do parto $(81,0 \pm 12,3$ e $77,0 \pm 17,8 \mathrm{~kg})$ e peso materno em três meses após o parto $(70,9 \pm 13,4$ e 66,8 $8 \pm 16,7 \mathrm{~kg})$.

Não foram observadas diferenças significativas na ingestão alimentar dos dois grupos, incluindo o selênio $(45 \pm 13 \mu \mathrm{g} / \mathrm{dia}$ no grupo tratamento e $44 \pm 18 \mu \mathrm{g} /$ dia no grupo placebo). Assim, o consumo médio diário de selênio das gestantes que receberam a suplementação foi de cerca de $95 \mu \mathrm{g} / \mathrm{dia}$ e das gestantes não suplementadas de aproximadamente $44 \mu \mathrm{g} / \mathrm{dia}$.

\section{MOORE e col. (2000)}

As participantes dos grupos tratamento e placebo eram semelhantes em idade ( $25 \pm 1$ e $23 \pm 1$ anos), no hematócrito (39 \pm 2 e $41 \pm 2 \%$ ) e na hemoglobina $(130 \pm 7$ e $130 \pm 7 \mathrm{~g} / \mathrm{L})$. No entanto, os valores de hematócrito e hemoglobina apresentados se referem ao final da gestação.

NEGRO e col. (2007)

Para os grupos S1, S0 e C são apresentados dados semelhantes, resumidos pela média \pm desvio-padrão, respectivamente, quanto à idade (28 $\pm 6,28 \pm 5$ e $27 \pm 5$ anos), paridade (60/17, 56/18 e 59/22 estavam na primeira gestação), $T_{4}$ livre $(12,4 \pm 2,2 ; 12,2 \pm 2,1$ e 14,0 $\pm 2,1 \mathrm{ng} / \mathrm{l})$, idade gestacional na primeira visita endocrinológica $(9,6 \pm 3,2 ; 9,4 \pm 2,5$ e $9,5 \pm 2,8$ semanas) e hipotireoidismo após o parto $(5,2 \%$ no grupo tratamento e $6,8 \%$ no grupo placebo). 
As pacientes TPOAb+ que apresentaram valores de TSH acima do normal e/ou valores de $\mathrm{T}_{4}$ livre menores que o normal iniciaram ainda durante a gestação tratamento com levotiroxina $\left(\mathrm{LT}_{4}\right)$, para evitar complicações fetais ou obstétricas. A administração do $L_{4}$ foi ajustada para manter os valores de $\mathrm{T}_{4}$ livre no tercil médio-superior e os de TSH inferiores a 2,5mlU/litro. Após o parto, a administração de $L_{T}$ foi descontinuada, e o tratamento substitutivo foi iniciado nas pacientes com hipotireoidismo com valores de TSH maiores que $10 \mathrm{mIU} /$ litro. As pacientes que receberam tratamento substitutivo durante o pós-parto (dentro de 12 meses após o parto) descontinuaram o uso de $\mathrm{LT}_{4}$ no final desse período para que se determinasse se a condição de hipotireoidismo era permanente. A administração de $\mathrm{LT}_{4}$ no pós-parto foi ajustada para manter as concentrações de $\mathrm{TSH}_{\text {e }} \mathrm{FT}_{4}$ dentro dos limites de normalidade.

\section{THOMSON e col. (2001)}

No início do estudo os grupos Preg-Se, Preg+Se e NonPreg+Se, respectivamente, apresentavam características semelhantes resumidas pelas médias \pm desvios-padrão quanto à idade $(27 \pm 5,29 \pm 3$ e $27 \pm 5$ anos), ao índice de massa corporal $\left(24 \pm 4,25 \pm 6\right.$ e $\left.24 \pm 5 \mathrm{~kg} / \mathrm{m}^{2}\right)$, à concentração plasmática de selênio $(0,76 \pm 0,15 ; 0,81 \pm 0,13$ e $0,73 \pm 0,21 \mu \mathrm{mol} / \mathrm{L})$, à excreção urinária de selênio em 24 horas $(0,24 \pm 0,11 ; 0,22 \pm 0,07$ e $0,20 \pm 0,08 \mu \mathrm{mol} / \mathrm{dia})$, à concentração urinária de selênio $(0,19 \pm 0,15$; $0,17 \pm 0,06$ e $0,16 \pm 0,05 \mu \mathrm{mol} / \mathrm{L})$, à razão selênio/creatinina $(31 \pm 9 ; 27 \pm 8 \mathrm{e}$ $28 \pm 11 \mu \mathrm{mol} / \mathrm{mol})$ e à depuração renal do selênio plasmático $(22 \pm 9 ; 19 \pm 5 \mathrm{e}$ $18 \pm 11 \mathrm{~L} / \mathrm{min})$. 


\subsection{EFEITOS DA SUPLEMENTAÇÃO DE SELÊNIO NOS DESFECHOS RELACIONADOS À GESTANTE/PARTURIENTE}

\subsubsection{Ocorrência de morbidade materna}

$>$ NEGRO e col. (2007)

Os autores investigam em seu estudo a ocorrência de hipertensão e pré-eclampsia durante a gestação e a função tireoidiana na gestação e no pós-parto, por meio de dosagens de $\mathrm{TSH}$, de $\mathrm{T}_{4}$ livre e de ultrassonografias da tireóide.

Os autores relatam não terem sido encontradas diferenças entre os grupos S1 e S0 no que se refere à ocorrência de hipertensão e préeclampsia. Para tais achados não são apresentadas as incidências e valores de $p$.

No que diz respeito à função tireoidiana durante a gestação, as participantes dos grupos S1 e S0 tinham concentrações de TSH $(1,6 \pm 0,6$ e $1,7 \pm 0,7 \mathrm{mIU} / \mathrm{l}$, respectivamente) significativamente maiores que as do grupo C $(0,9 \pm 0,4 \mathrm{mIU} / \mathrm{l})$, com $\mathrm{p}<0,01$, e mais frequentemente precisaram de $\mathrm{LT}_{4}$ nesse período $(19,4 \%$ e $21,6 \%$ contra $2,5 \%$ nos controles). Não houve diferença estatística nas doses de $\mathrm{LT}_{4}$ administradas para os grupos $\mathrm{S} 1 \mathrm{e}$ S0, que receberam em média $52,4 \pm 16 \mu \mathrm{g} /$ dia. Das participantes que fizeram uso de $\mathrm{LT}_{4}, 64,5 \%$ iniciaram o tratamento na $20^{\mathrm{a}}$ semana e $35,5 \%$ na $30^{\mathrm{a}}$ semana de gestação. Dois meses após o parto e com o fim do tratamento com $\mathrm{LT}_{4}, 5,2 \%$ do grupo $\mathrm{S} 1$ e $6,8 \%$ do grupo S0 apresentavam hipotireoidismo.

Durante o período pós-parto (até 12 meses), 28,6\% das participantes do grupo $S 1(n=22)$ desenvolveram disfunção da tireóide, sendo que no final deste período $11,7 \%$ apresentavam hipotireoidismo permanente. No grupo S0, 48,6\% das participantes $(n=36)$ desenvolveram disfunção da tireóide, e ao final do período 20,3\% tinham hipotireoidismo permanente. As diferenças foram estatisticamente significantes entre os grupos, com $p<0,01$, tanto para 
a disfunção da tireóide no período pós-parto quanto para o hipotireoidismo permanente. Em relação ao padrão de disfunção da tireóide, quando considerados os grupos S0 e $\mathrm{S} 1$ juntos, $58,6 \%$ das participantes desenvolveram hipotireoidismo, 34,5\% apresentavam padrão bifásico de alteração da tireóide e 6,9\% desenvolveram hipertireoidismo, com padrões de disfunção semelhantes entre os grupos. Já no grupo C, somente $3,7 \%$ das participantes $(n=3)$ apresentaram disfunção da tireóide, das quais uma apresentou tirotoxicose transitória no pós-parto e as outras duas apresentaram um padrão bifásico.

Quanto à presença dos anticorpos TPOAb durante a gestação, os grupos S1 e S0 eram semelhantes na $10^{\mathrm{a}}$ semana $(627 \pm 42$ e 580 539 kIU/litro) e apresentaram redução significante no período gestacional quando comparados ao baseline, sendo esta redução estatisticamente maior no grupo S1 $(62,4 \%)$ quando comparado ao $S 0(43,9 \%)$, com $p<0,01$. No período de até 12 meses após o parto, ambos os grupos experimentaram um intenso aumento dos anticorpos, nos cinco meses subseqüentes ao

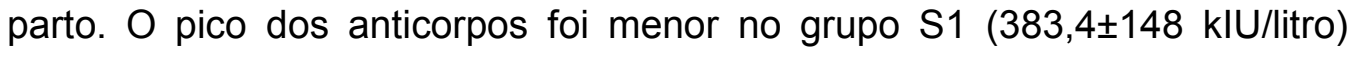
quando comparado ao S0 $(745,5 \pm 257 \mathrm{kIU} / \mathrm{litro})$, com $\mathrm{p}<0,01$. No período pós-parto, foram observados menos anticorpos TPOAb no grupo S1 comparado ao grupo S0 $(323,2 \pm 44$ e $621,1 \pm 80 \mathrm{kIU} /$ litro, respectivamente, $\mathrm{p}<0,01)$.

Durante a gestação, as ultrassonografias apontaram que 15,6\% das participantes do grupo $\mathrm{S} 1$ tinham ecogenicidade normal do parênquima da tireóide (grau 0), enquanto 59,7\% tinham tireoidite leve (grau 1), 15,6\% tireoidite moderada (grau 2) e 9,1\% tireoidite avançada (grau 3). No grupo S0, $13,5 \%$ das participantes tinham ecogenicidade normal do parênquima da tireóide (grau 0), 63,5\% tinham tireoidite leve (grau 1), 21,6\% tireoidite moderada (grau 2) e 5,4\% tireoidite avançada (grau 3). As distribuições dos padrões de ecogenicidade foram estatisticamente semelhantes entre os grupos.

No momento do parto, $16,9 \%$ das participantes do grupo $\mathrm{S} 1$ tinham ecogenicidade normal (grau 0), 61\% tireoidite leve (grau 1), 14,3\% tireoidite 
moderada (grau 2) e 7,8\% tireoidite avançada (grau 3). No grupo S0, 14,8\% das participantes tinham ecogenicidade normal (grau 0), 64,9\% tireoidite leve (grau 1), 12,2\% tireoidite moderada (grau 2) e 8,1\% tireoidite avançada (grau 3). As distribuições dos padrões de ecogenicidade também foram estatisticamente semelhantes entre os grupos.

No final do período pós-parto, $10,4 \%$ das participantes do grupo $\mathrm{S} 1$ apresentavam ecogenicidade normal do parênquima da tireóide (grau 0), $62,3 \%$ tinham tireoidite leve (grau 1), 16,9\% tireoidite moderada (grau 2) e $10,4 \%$ tireoidite avançada (grau 3). No grupo so, 10,8\% tinham ecogenicidade normal (grau 0), 44,6\% tireoidite leve (grau 1), 35,1\% tireoidite moderada (grau 2) e 9,5\% tireoidite avançada (grau 3).

Apesar de não ter sido observada diferença nos padrões de ecogenicidade do grupo S1 quando comparados na gestação, no parto e no pós-parto $(p<0,05)$, no grupo $S 0$ houve piora significativa no pós-parto quando comparado ao começo da gestação e ao parto $(p<0,05)$. Avaliandose os padrões de ecogenicidade entre os grupos S1 e S0, as participantes que receberam suplementação apresentaram uma proporção de tireoidite graus 2 e 3 estatisticamente menor no final do período pós-parto quando comparadas às não suplementadas $(p<0,01)$.

Os desfechos relativos à presença de tireoidite encontram-se descritos na Tabela 2 a seguir. 
Tabela 2: Presença de tireoidite nas gestantes TPOAb+ que receberam placebo (S0) e TPOAb+ suplementadas com selênio (S1).

\begin{tabular}{lcc}
\hline Presença de Tireoidite & $\begin{array}{c}\text { Grupo S0 } \\
\%\end{array}$ & $\begin{array}{c}\text { Grupo S1 } \\
\%\end{array}$ \\
\hline Gestação & & \\
Leve (grau 1) & 63,5 & 59,7 \\
Moderada (grau 2) & 21,6 & 15,6 \\
Avançada (grau 3) & 5,4 & 9,1 \\
Parto & & \\
Leve (grau 1) & 64,9 & 61,0 \\
Moderada (grau 2) & 12,2 & 14,3 \\
Avançada (grau 3) & 8,1 & 7,8 \\
Pós-parto & & \\
Leve (grau 1) & 44,6 & 62,3 \\
Moderada (grau 2) & 35,1 & 16,9 \\
Avançada (grau 3) & 9,5 & 10,4 \\
\hline Fonte: NEGRO e col., (2007) & &
\end{tabular}

\subsubsection{Ocorrência de desfechos gestacionais adversos}

NEGRO e col. (2007)

Os autores relataram que não havia diferenças estatísticas entre os grupos S1 e S0 no que diz respeito à ocorrência de abortos, ruptura prematura de membrana e partos prematuros, sem apresentar medidasresumo e valores descritivos dos testes estatísticos.

4.5.3 Ocorrência de efeitos colaterais da suplementação

NEGRO e col. (2007)

De acordo com os autores não foram relatados efeitos adversos decorrentes da exposição a excesso de selênio no grupo suplementado, não sendo apresentados medidas-resumo ou valores descritivos de testes 
estatísticos, tampouco foi apresentada lista dos principais efeitos considerados.

\subsubsection{Concentrações plasmáticas e sanguíneas de selênio}

MOORE e col. (2000)

As gestantes que receberam suplementação com selênio apresentaram concentração plasmática média do mineral estatisticamente maior em relação àquelas que não receberam a suplementação $(100 \pm 7 \mathrm{ng} / \mathrm{g}$ e $35 \pm 7 \mathrm{ng} / \mathrm{g}$, respectivamente, $\mathrm{p}<0,05)$. Foi observada interação entre a suplementação e o tempo. Assim, o estudo apresenta graficamente os valores médios para cada momento avaliado. Entre as mulheres suplementadas, no período de duas semanas após o parto as concentrações plasmáticas de selênio diminuíram para $85 \pm 7 n g / g$ de plasma $(p<0,001)$ e permaneceram constantes na $4^{a}$ e na $12^{a}$ semanas $(80 \pm 7 n g / g$ e $86 \pm 7 n g / g$, respectivamente). Nas mulheres não suplementadas, foi observado um padrão diferente nas concentrações plasmáticas de selênio: após o parto, estas subiram para $47 \pm 7 n g / g$ na $2^{a}$ semana $(p=0,013)$ e para $52 \pm 7 n g / g$ na $4^{a}$ semana $(p=0,0015)$. Na $12^{a}$ semana após o parto, a concentração plasmática de selênio reduziu para $28 \pm 7 \mathrm{ng} / \mathrm{g}$, valor estatisticamente semelhante ao observado no momento do parto. Em todos os tempos avaliados, as concentrações plasmáticas médias de selênio foram estatisticamente maiores nas mulheres que receberam a suplementação $(p<0,013)$.

\section{> THOMSON e col. (2001)}

Os autores descrevem o comportamento das concentrações plasmáticas de selênio nos três grupos de tratamento ao longo do período gestacional e do pós-parto. Assim, no sentido de facilitar o entendimento desses resultados, os mesmos encontram-se descritos a seguir e esquematizados mais adiante, no Quadro 10. 
Houve redução das concentrações plasmáticas de selênio durante a gravidez no grupo Preg-Se $\left(2^{\circ}\right.$ mês comparado aos $6^{\circ}, 7^{\circ}, 8^{\circ}$ e $9^{\circ}$ meses, $p<0,01)$, que retornaram ao valor inicial no $3^{\circ}$ mês pós-parto. O grupo Preg+Se apresentou um aumento inicial nas concentrações plasmáticas do mineral $\left(2^{\circ}\right.$ mês comparado aos $3^{\circ}, 4^{\circ}$ e $5^{\circ}$ meses, $\left.p<0,02\right)$, com subsequente redução do $6^{\circ}$ ao $9^{\circ}$ mês $\left(5^{\circ}\right.$ mês comparado aos $8^{\circ}$ e $9^{\circ}$ meses, $p<0,05)$ e aumento no $3^{\circ}$ mês pós-parto, do mesmo modo como foi observado no grupo NonPreg+Se $(p<0,002)$. Em todos os momentos avaliados as concentrações plasmáticas de selênio foram maiores no grupo Preg+Se quando comparado ao grupo Preg-Se $(p<0,02)$ (Quadro 10).

As concentrações plasmáticas de selênio do grupo NonPreg+Se atingiram um platô após um mês de intervenção (equivalente ao $3^{\circ}$ mês de gravidez do grupo das gestantes). Esse platô foi mantido até o final do período de suplementação $\left(2^{\circ}\right.$ mês comparado ao $3^{\circ}$ mês e $2^{\circ}$ mês comparado ao equivalente ao $6^{\circ}$ mês pós-parto, $\left.p<0,01\right)$. Ao contrário do que foi observado no grupo Preg+Se, no grupo NonPreg+Se não houve redução das concentrações plasmáticas de selênio após essas terem atingido o platô, o que fez com que no $8^{\circ}$ e $9^{\circ}$ mês essas concentrações fossem maiores que aquelas observadas no grupo Preg+Se $(p<0,02)$. As concentrações plasmáticas de selênio também foram maiores no grupo NonPreg+Se $(p=0,013)$. O platô observado mais tardiamente no grupo Preg+Se pode ser explicado pelo fato de que algumas gestantes iniciaram a suplementação a partir do $3^{\circ}$ mês de gestação, ao contrário do grupo NonPreg+Se, em que todas as mulheres iniciaram a suplementação no mesmo momento, que correspondia ao $2^{\circ}$ mês de gestação. Quando os autores avaliaram o selênio plasmático por grama de proteína foram observadas tendências semelhantes, apesar de a diminuição no final da gestação não ser tão pronunciada (resultados não apresentados) (Quadro 10). 
Quadro 10 - Comportamento das concentrações de selênio de gestantes que receberam placebo (Preg-Se) ou suplementos de selênio (Preg+Se) durante a gestação e a lactação e de seus controles não gestantes (NonPreg+Se).

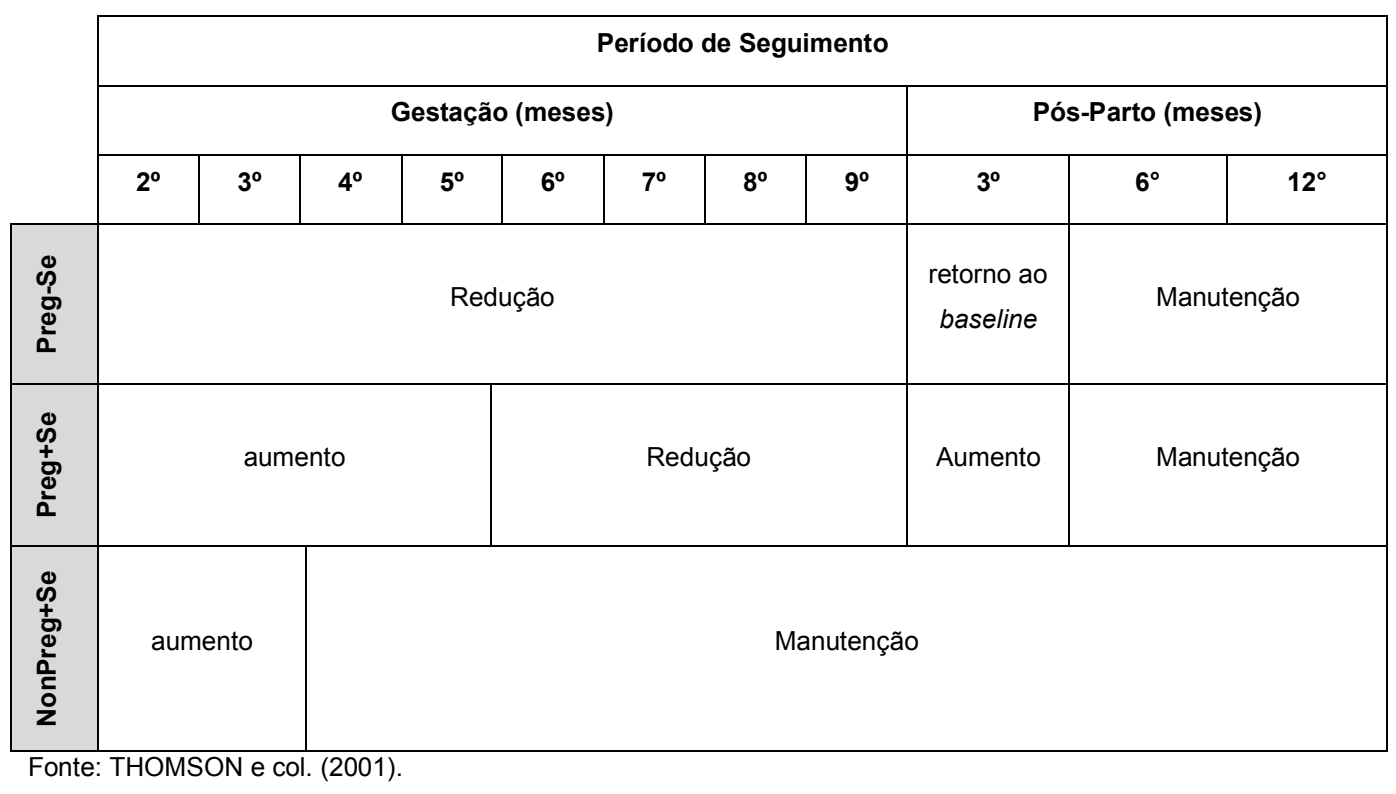

NEGRO e col. (2007)

Ao mensurarem as concentrações sanguíneas de selênio os autores encontraram valores estatisticamente semelhantes entre os grupos na $10^{\mathrm{a}}$ semana de gestação $(80,9 \pm 2,4 \mu \mathrm{g} /$ litro para o grupo $S 1,78,2 \pm 2,3 \mu \mathrm{g} / \mathrm{litro}$

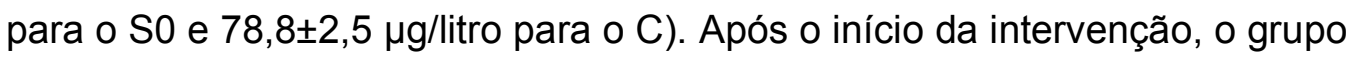
S1 apresentou concentrações sanguíneas de selênio significativamente maiores que os grupos S0 e C em cada momento avaliado $(p<0,01)$. No grupo S1, as concentrações sanguíneas de selênio foram significativamente maiores que no baseline durante todo o período de seguimento $(p<0,01)$. Nos grupos SO e C, as concentrações sanguíneas de selênio foram estatisticamente menores na $30^{\mathrm{a}}$ semana de gestação quando comparadas às da $10^{\mathrm{a}}$ semana $(p<0,05)$, voltando ao valor observado no início do estudo após o parto. As concentrações de selênio dos grupos So e C não diferiram estatisticamente. 


\subsubsection{Excreção urinária de selênio}

THOMSON e col. (2001)

Foi observado que tanto a excreção diária de selênio como a razão selênio/creatinina do grupo Preg-Se se mantiveram constantes durante a gestação, declinando entre o nascimento e o $3^{\circ}$ mês pós-parto $(p<0,005$ quando comparados o $8^{\circ}$ mês de gestação e o $3^{\circ}$ mês pós-parto). No grupo Preg+Se, tanto a excreção diária de selênio quanto a razão selênio/creatinina aumentaram, alcançando um platô no $4^{\circ}$ mês de gestação, que correspondeu aproximadamente ao $2^{\circ}$ mês de suplementação $(p<0,05$ quando comparados o $2^{\circ}$ e o $3^{\circ}$ mês; $p<0,005$ quando $\circ 2^{\circ}$ mês é comparado ao período do $4^{\circ}$ ao $8^{\circ}$ mês), permanecendo elevada após o nascimento $\left(p<0,01\right.$ quando comparados o $2^{\circ}$ mês de gestação e o $3^{\circ}$ mês pós-parto). A redução do número de gestantes no $9^{\circ}$ mês poderia explicar a rápida queda nos valores da excreção urinária de selênio em 24 horas e da razão selênio/creatinina, sendo possível que os valores médios apresentados no gráfico não representem o grupo como um todo. Em todos os momentos, do $5^{\circ}$ ao $8^{\circ}$ mês de gestação $(p<0,05)$ e do $3^{\circ}$ ao $12^{\circ}$ mês pós-parto $(p<0,002)$, os valores de ambas as medidas do grupo Preg+Se foram maiores que os do grupo Preg-Se. No grupo NonPreg+Se, a excreção urinária de selênio e a razão selênio/creatinina aumentaram até o $5^{\circ}$ mês, quando atingiram um platô ( $p<0,0005$ quando comparados o $2^{\circ}$ e o $5^{\circ}$ mês), permanecendo elevadas até o final da suplementação $(p<0,05$ quando comparados o $2^{\circ}$ mês e o período equivalente ao $12^{\circ}$ mês pós-parto). A excreção urinária de selênio em 24 horas do grupo Preg+Se tendeu a ser maior que a do NonPreg+Se. No entanto, a diferença foi estatisticamente significante apenas no $6^{\circ}$ mês de gestação $(p=0,036)$.

Apesar de avaliarem a concentração de selênio na urina como uma das variáveis relativas à excreção urinária de selênio, os autores não apresentam o comportamento dessa medida devido à presença de maiores variações individuais. 
Os valores médios das medidas de selênio na urina (excreção em 24 horas, razão selênio/creatinina e concentração de selênio) da gestação ( $4^{\circ}$ ao $8^{\circ}$ mês) foram comparados aos valores médios das medidas do pós-parto $\left(3^{\circ}\right.$ ao $12^{\circ}$ mês). Observou-se que o grupo Preg-Se apresentou valores estatisticamente maiores de concentração urinária de selênio $(p=0,03)$, de excreção de selênio em 24 horas $(p=0,0002)$ e razão selênio/creatinina $(p=0,0063)$. Já o grupo Preg+Se apresentou excreção em 24 horas estatisticamente maior $(p=0,045)$. Esses resultados indicam maior excreção urinária de selênio durante a gestação.

Houve correlação inversa entre o volume de urina e a concentração de selênio $(r=0,53, p=0,05)$, mas não foram encontradas correlações entre o volume de urina e a excreção de selênio em 24 horas ou a razão selênio/creatinina. A concentração urinária de selênio e a razão selênio/creatinina estavam estatisticamente correlacionadas à concentração plasmática de selênio ( $r=0,29$ e 0,33; respectivamente). Foram encontradas correlações estatisticamente significantes para o clearance de creatinina e as medidas de excreção urinária de selênio $(0,47$ para a excreção em 24 horas; 0,28 para a concentração de selênio; 0,31 para a razão selênio/creatinina e 0,48 para o clearance renal de selênio). Não foram encontradas evidências da relação entre o selênio e o iodo nas três mensurações na urina.

\subsubsection{Atividade plasmática de glutationa peroxidase}

\section{MOORE e col. (2000)}

No momento do parto, a atividade GPX foi significativamente maior nas gestantes que receberam suplementação comparadas aos controles sem suplementação. Entre as gestantes não suplementadas, a atividade foi de $175 \pm 34 \mathrm{mmol} / \mathrm{min} / \mathrm{mL}$, enquanto para as suplementadas o resultado foi apresentado apenas no gráfico, indicando valor acima de $400 \mathrm{mmol} / \mathrm{min} / \mathrm{mL}$. O valor de p não foi apresentado. 
Nas gestantes suplementadas, a atividade plasmática da GPX apresentou seus maiores níveis no parto, diminuindo constantemente ao longo do tempo. Duas semanas após o parto, a média da atividade plasmática da GPX $(381 \pm 34 \mathrm{mmol} / \mathrm{min} / \mathrm{mL})$ foi estatisticamente menor que durante o parto $(p=0,014)$. Quatro semanas após o parto, a média da atividade plasmática $(332 \pm 34 \mathrm{mmol} / \mathrm{min} / \mathrm{mL})$ foi estatisticamente menor que aquela na $2^{a}$ semana $(p=0,011)$. A média da atividade plasmática foi ainda menor na $12^{\mathrm{a}}$ semana após o parto $(293 \pm 34 \mathrm{mmol} / \mathrm{min} / \mathrm{mL})$ quando comparada à da $4^{\mathrm{a}}$ semana $(p=0,044)$.

Nas gestantes não suplementadas, a atividade de GPX seguiu um padrão semelhante ao das concentrações plasmáticas de selênio: a média da atividade no momento do parto $(175 \pm 34 \mathrm{mmol} / \mathrm{min} / \mathrm{mL})$ aumentou significativamente na $2^{\mathrm{a}}$ semana $(276 \pm 34 \mathrm{mmol} / \mathrm{min} / \mathrm{mL}, \quad p=0,0001)$, permaneceu neste nível na $4^{\mathrm{a}}$ semana $(277 \pm 36 \mathrm{mmol} / \mathrm{min} / \mathrm{mL})$ e na $12^{\mathrm{a}}$ semana reduziu para nível estatisticamente equivalente ao observado no momento do parto $(175 \pm 34 \mathrm{mmol} / \mathrm{min} / \mathrm{mL})$.

Os resultados acima descritos encontram-se no Quadro 11 a seguir.

Quadro 11 - Comportamento da atividade de glutationa peroxidase em gestantes suplementadas com selênio durante a gestação e a lactação e gestantes sem suplementação.

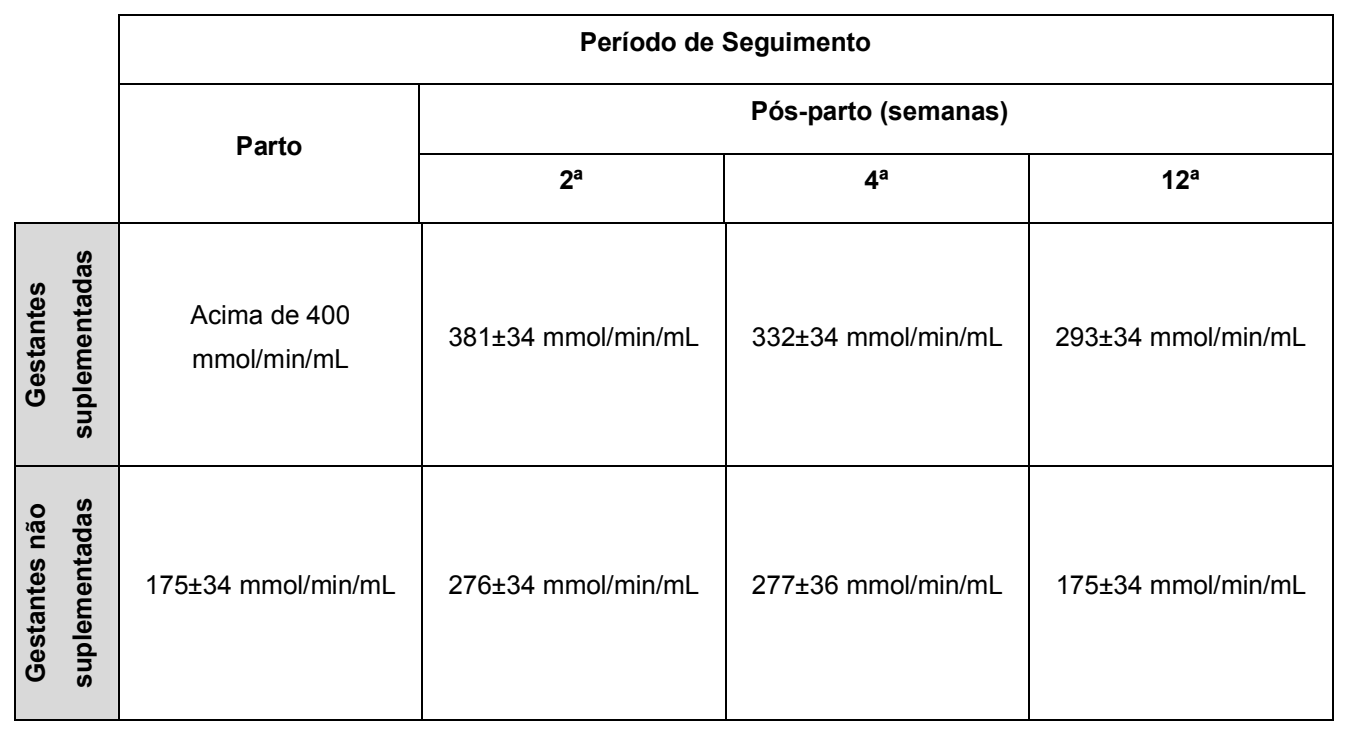


Foi encontrada interação entre a suplementação e o tempo e em todos os momentos avaliados a média da atividade plasmática de GPX foi estatisticamente maior nas mulheres que receberam suplementos comparadas às não suplementadas $(p<0,041)$.

\subsubsection{Marcadores de estresse oxidativo}

\section{MOORE e col. (2000)}

Os autores, ao avaliarem o estresse oxidativo por meio das concentrações plasmáticas de substâncias reativas com 0 ácido tiobarbitúrico (TBARS), encontraram interação entre a suplementação com selênio e o momento de avaliação (parto, $2^{\mathrm{a}}, 4^{\mathrm{a}}$ e $10^{\mathrm{a}}$ semana pós-parto), descrevendo então os dados para cada um desses momentos. Nas mulheres que foram suplementadas, as médias de TBARS permaneceram constantes na $2^{a}$ e $4^{a}$ semanas após o parto, mas diminuíram significativamente na $12^{a}$ semana $(p=0,014)$. Entre as mulheres não suplementadas, as concentrações médias de TBARS apresentaram padrões distintos: houve um aumento na $2^{a}(p=0,0004)$ e na $4^{a}$ semana após o parto $(p=0,0001)$, enquanto na $12^{a}$ semana a média foi significativamente menor que em qualquer outro momento $(p=0,007)$. Entre as mulheres que receberam a suplementação, as médias da concentração plasmática de TBARS foram significativamente maiores no parto $(p=0,04)$ e na $12^{a}$ semana $(p=0,038)$ quando comparadas às que não receberam o suplemento. Quando avaliados os dois grupos na $2^{\mathrm{a}}$ semana após o parto, não havia diferença estatística entre as concentrações médias de TBARS, contudo, na $4^{a}$ semana os valores foram significativamente maiores entre as mulheres não suplementadas $(p=0,0047)$. 


\subsubsection{Concentrações de selênio no leite materno}

$>$ MOORE e col. (2000)

Os autores referem interação entre a suplementação e o momento de avaliação das concentrações de selênio no leite materno, que foram significativamente maiores nas mulheres que receberam suplementação em todos os momentos $(p=0,037)$ e, por esse motivo, apresentam os valores para cada tempo avaliado.

Nas mulheres que receberam a suplementação, a concentração média de selênio no leite materno no momento do parto foi de $16,7 \pm 1,3 \mathrm{ng} / \mathrm{g}$, sem diferença estatística em relação ao valor observado na $1^{a}$ semana pósparto $(17,9 \pm 1,3 \mathrm{ng} / \mathrm{g})$, aumentando para $19,8 \pm 1,3 \mathrm{ng} / \mathrm{g}$ na $2^{\mathrm{a}}$ semana $(p=0,035)$. As concentrações médias diminuíram para $16,9 \pm 1,3 \mathrm{ng} / \mathrm{g}$ na $3^{\mathrm{a}}$ semana e para $16,2 \pm 1,3 \mathrm{ng} / \mathrm{g}$ na $4^{\text {a }}$ semana pós-parto. Apesar de estes valores serem semelhantes ao do parto $(p=0,044)$, eles eram estatisticamente menores que a concentração na $2^{a}$ semana $(p=0,013) . \mathrm{Na}$ $12^{a}$ semana após o parto, a média de concentração de selênio para as mulheres suplementadas foi $9,9 \pm 1,3 \mathrm{ng} / \mathrm{g}$ de leite, o menor valor observado em todos os momentos avaliados $(p=0,0001)$.

Nas mulheres que receberam a suplementação, as concentrações de selênio do leite materno seguiram um padrão semelhante ao das que não foram suplementadas. A concentração de selênio no momento do parto $(7,4 \pm 1,3 \mathrm{ng} / \mathrm{g}$ leite $)$ foi estatisticamente semelhante à da $2^{\mathrm{a}}$ semana pós-parto (valor médio apresentado apenas no gráfico). Na $3^{a}$ semana, a concentração média de selênio no leite materno foi $11,7 \pm 1,3 \mathrm{ng} / \mathrm{g}$, sendo semelhante à da $2^{a}$ semana, porém estatisticamente maior que a do parto $(p=0,004)$ e a da $1^{a}$ semana $(p=0,032)$. Na $4^{a}$ semana, a concentração média de selênio diminuiu para $8,4 \pm 1,3 \mathrm{ng} / \mathrm{g}$ de leite, valor estatisticamente inferior ao da $3^{\mathrm{a}}$ semana $(p=0,024)$, mas semelhante aos valores encontrados na $1^{\mathrm{a}}$ e $2^{\mathrm{a}}$ semanas. 
$>$ DODGE e col. (1999)

Os autores verificaram que a suplementação com selênio promoveu um aumento estatisticamente significante na quantidade do mineral no leite materno $(p=0,003)$. Foram relatadas concentrações médias de selênio entre 1 e 7 dias pós-parto $(12,9 \pm 0,4 \mathrm{ng} / \mathrm{mL})$ e aos 3 meses pós-parto $(9,4 \pm 0,5$ $\mathrm{ng} / \mathrm{mL})$, com diferença estatisticamente significante $(p=0,0002)$, indicando que o momento no qual as amostras são obtidas influenciam a quantidade de selênio no leite.

4.5.9 Atividade de glutationa peroxidase no leite materno

DODGE e col. (1999)

Não houve diferença estatisticamente significante na atividade de GPX no leite materno ao comparar gestantes suplementadas e não suplementadas, em ambos os momentos avaliados (1 a 7 dias pós-parto e 3 meses pós-parto). Não foi encontrado efeito do tempo em que as amostras foram coletadas na atividade desta enzima no leite materno, indicando quantidades semelhantes nos dois momentos. Os dados são apresentados apenas graficamente e não está claro na figura e no texto o momento de sua obtenção.

4.5.10 Perfil de ácidos graxos do leite materno

DODGE e col. (1999)

Houve redução da quantidade total de ácidos graxos saturados do leite materno: a concentração no grupo não suplementado foi de $50,1 \pm 2,0 \mathrm{~g} / 100 \mathrm{~g}$ contra $44,4 \pm 1,6 \mathrm{~g} / 100 \mathrm{~g}$ no grupo suplementado, com $p=0,04$.

As concentrações de ácidos graxos poliinsaturados (PUFA) foram estatisticamente menores nas gestantes que não receberam a suplementação $(9,70 \pm 1,24 \mathrm{~g} / 100 \mathrm{~g})$ em relação às que receberam $(13,70 \pm 1,02 \mathrm{~g} / 100 \mathrm{~g})$, com $\mathrm{p}=0,02$. O aumento observado é explicado pelo conteúdo de ácidos graxos $\mathrm{n}-6$, cuja soma aumentou de $8,30 \pm 1,17 \mathrm{~g} / 100 \mathrm{~g}$ 
(grupo não suplementado) para 12,08 $\pm 0,97 \mathrm{~g} / 100 \mathrm{~g}$ (grupo suplementado), representando um aumento de $44 \%(p=0,02)$. Dentre os ácidos graxos poliinsaturados n-6, o de maior contribuição para o aumento do conteúdo total de ácidos graxos poliinsaturados no leite materno foi o ácido linoléico,

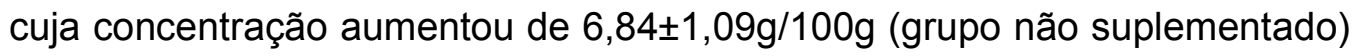
para $10,29 \pm 0,90 \mathrm{~g} / 100 \mathrm{~g}$ (grupo suplementado), com $\mathrm{p}=0,02$.

As concentrações de vários PUFA foram estatisticamente maiores no leite coletado entre 1 e 7 dias após o parto em comparação ao leite maduro, com diferenças estatisticamente significantes para os ácidos graxos 20:5(n3) $(0,15 \pm 0,03$ vs. $0,08 \pm 0,02 \mathrm{~g} / 100 \mathrm{~g}), 22: 5(\mathrm{n}-3)(0,30 \pm 0,02$ vs. $0,17 \pm 0,02$ $\mathrm{g} / 100 \mathrm{~g}), 22: 6(\mathrm{n}-3)(0,45 \pm 0,02$ vs. $0,18 \pm 0,03 \mathrm{~g} / 100 \mathrm{~g})$ e para a soma dos PUFA (n-3) $(1,73 \pm 0,11$ vs. $1,30 \pm 0,15 \mathrm{~g} / 100 \mathrm{~g})$.

A concentração total de ácidos graxos monoinsaturados (MUFA) foi estatisticamente maior no leite materno de mulheres que receberam suplementação $(38,68 \pm 1,15 \mathrm{~g} / 100 \mathrm{~g})$ quando comparadas a mulheres não suplementadas $(34,96 \pm 1,40 \mathrm{~g} / 100 \mathrm{~g})$, com $\mathrm{p} \leq 0,05$. O tempo em que as amostras de leite foram coletadas teve influência mínima na concentração de MUFA.

$>$ MOORE e col. (2000)

Os autores referem não ter encontrado diferença significativa no perfil de ácidos graxos do leite materno quando comparados os grupos de mulheres suplementadas e não suplementadas durante a gestação. As medidas resumo e os valores descritivos dos testes estatísticos não foram apresentados. 


\subsection{EFEITOS DA SUPLEMENTAÇÃO DE SELÊNIO NOS DESFECHOS RELACIONADOS AO RECÉM-NASCIDO}

\subsubsection{Peso ao nascer}

$>$ NEGRO e col. (2007)

Segundo os autores, não foram encontradas diferenças significativas entre o grupo que recebeu suplementação quando comparado ao grupo que não recebeu, embora não sejam apresentadas as médias, desvios-padrão e valor de $p$ para esse desfecho.

\subsubsection{Escore de APGAR}

$>$ NEGRO e col. (2007)

De acordo com os autores, não foi encontrada diferença significativa quando comparados o grupo que recebeu suplementação de selênio e o grupo controle. Semelhantemente, as médias e valor de $p$ não foram apresentados. 


\section{DISCUSSÃO}

\subsection{BUSCA E SELEÇÃO DOS ESTUDOS}

Este estudo apresenta uma revisão de literatura, seguindo uma metodologia que permite replicar os resultados e identificar estudos com qualidade que contribuam para a agregação de evidências científicas.

Nesta revisão sistemática, optou-se pela realização da busca por estudos publicados em um grande número de bases de dados, aumentando a chance de que todos os trabalhos relevantes já publicados sobre o tema fossem encontrados. Em adição, a conferência das listas de referências dos estudos selecionados indicou que nenhum trabalho adicional tivesse deixado de ser encontrado por meio da busca eletrônica.

Dos 76 trabalhos elegíveis e seus respectivos resumos encontrados, $14,5 \%$ foram selecionados para leitura na íntegra e dois para leitura dos métodos para a tomada de decisão. Esse percentual pode ter se dado especialmente pela elaboração de estratégias de busca mais amplas, baseadas no interesse em incluir diversos desenhos metodológicos, pois era conhecida a existência de poucos ensaios clínicos aleatorizados controlados que avaliassem a suplementação com selênio em gestantes. No entanto, durante a leitura dos 76 resumos, foi possível perceber que a grande maioria dos estudos avaliava o papel do selênio no período gestacional, embora muitos fossem de desenho transversal sem suplementação ou estudos de suplementação com outros micronutrientes associados, indicando que as estratégias de busca foram sensíveis.

No caso de estratégias muito amplas e pouco sensíveis, é possível que uma grande parcela de resumos encontrados não contenha as características de interesse e, portanto, a identificação de um estudo elegível pode passar a ser um evento raro (OLIVEIRA e col., 2006). 


\subsection{AVALIAÇÃO DE QUALIDADE METODOLÓGICA}

A avaliação da qualidade metodológica de um estudo é considerada uma ferramenta essencial para que se julguem sua relevância e suas limitações (MOHER e col., 2001).

O instrumento proposto por DOWNS e BLACK (1998) apresentou-se como uma complementação àqueles propostos pela Cochrane Collaboration, pois permite uma avaliação global da qualidade dos estudos por considerar características referentes à aleatorização, à alocação, ao seguimento e à análise dos dados, e ainda por incluir itens relativos ao modo de divulgação (reporting) e à validade interna e externa dos estudos. O emprego de critérios amplos de qualidade metodológica tais quais os propostos no instrumento de DOWNS \& BLACK (1998) é de grande valia porque permite identificar estudos bem conduzidos, especialmente quando não se tratam de ensaios clínicos aleatorizados controlados. Quando se utilizou esta ferramenta, foi possível avaliar os artigos com uma visão mais ampla, identificando-se características positivas que iam além da aleatorização e do cegamento. Pode-se afirmar, inclusive, que o instrumento de DOWNS \& BLACK facilita a leitura e o julgamento dos artigos como um todo, independentemente da necessidade de classificá-lo para inclusão ou não em uma revisão sistemática de literatura.

No entanto, uma limitação do instrumento de DOWNS \& BLACK que merece destaque é o fato deste não ponderar de forma diferente os critérios avaliados, diminuindo a importância de itens de grande relevância nos ensaios clínicos aleatorizados controlados, na medida em que iguala o peso da aleatorização e do cegamento a características como, por exemplo, a forma de apresentação dos valores de $p$ (questão 10 do instrumento). Em adição, os autores não estabeleceram um ponto de corte para a classificação dos estudos, ficando a critério do avaliador a decisão sobre qual pontuação utilizar, conferindo arbitrariedade na decisão final do processo de avaliação. 
A partir da utilização das ferramentas para avaliação de qualidade dos estudos elegíveis para esta revisão, puderam ser observadas entre as limitações destes estudos, principalmente, descrição insuficiente relativas à população de estudo e ao local onde o mesmo foi conduzido, dificultando a avaliação de sua validade externa e, consequentemente, a extrapolação dos resultados; a ausência de descrições relativas ao processo de seleção e aleatorização da população, quando aplicável; a ausência de cálculos de tamanho amostral e a não consideração de fatores de confusão na análise dos dados, quando aplicável.

Os ensaios clínicos aleatorizados controlados necessitam de cálculos de amostra definidos com base nos seus principais desfechos, na fixação das probabilidades de erro tipos I e II e na grandeza esperada na diferença entre os tratamentos. Cada um desses aspectos deve ser claramente explicitado para que se consiga avaliar sua adequação (STONE e POCOCK, 2010).

É aceito que na ausência de ensaios clínicos aleatorizados controlados duplo-cegos podem-se obter estimativas de efeitos de intervenções a partir de outros tipos de estudos, desde que bem desenhados (EGGER e col., 2006). Adicionalmente, segundo STONE e POCOCK (2010), muitas perguntas não podem ser respondidas por meio de ensaios clínicos aleatorizados controlados, fazendo com que por vezes decisões em saúde sejam tomadas a partir de outros tipos de estudos, dentre eles os observacionais. Ainda de acordo com os autores, frequentemente não é viável realizar o duplo-cegamento em ensaios clínicos, o que não necessariamente comprometerá seus resultados desde que os protocolos de pesquisa sejam obedecidos e que medidas adequadas para a redução de vieses sejam adotadas. Uma crítica que pode ser feita à avaliação de qualidade é que esta pode ter grande variação, e o fato de um estudo ser aleatorizado não assegura sua qualidade metodológica ou relevância clínica.

Em geral, é preciso que todo o planejamento do estudo seja descrito em sua metodologia com detalhes suficientes para que se possa avaliar se os métodos utilizados foram adequados para fornecer resultados confiáveis e válidos, bem como se qualquer alteração no que foi inicialmente planejado 
de fato era cabível (VANDENBROUCKE e col., 2007; VON ELM e col., 2008). Assim, destaca-se que, independentemente do desenho do estudo, a ausência de descrição apropriada dos métodos empregados interfere no seu entendimento, prejudicando a avaliação de seus méritos e limitações e podendo, inclusive, fazer com que este receba uma credibilidade que não é verdadeira, especialmente no caso de estudos bem conduzidos, porém com um reporting inadequado (MOHER et al., 2001).

Nesse sentido, foram desenvolvidos e apresentados na literatura checklists que auxiliam na melhora da qualidade da divulgação (reporting) de diversos tipos de estudos, dentre os quais se destacam o CONSORT (Consolidated Standards of Reporting Trials), utilizado para ensaios clínicos aleatorizados controlados, e o STROBE (Strengthening the Reporting of Observational Studies in Epidemiology), empregado para estudos transversais, de coorte ou caso-controle (MOHER e col., 2001; VANDENBROUCKE e col., 2007; VON ELM e col., 2008). Interessantemente, no processo de avaliação dos estudos incluídos nesta revisão observou-se uma evolução positiva na qualidade do reporting ao longo dos anos de publicação, possivelmente como um reflexo do emprego cada vez mais frequente destes checklists.

\subsection{CARACTERÍSTICAS METODOLÓGICAS DOS ESTUDOS INCLUÍDOS}

Dos quatro estudos incluídos, três eram ensaios clínicos aleatorizados controlados (DODGE e col., 1999; NEGRO e col., 2007); THOMSON e col., 2001) e um tratava-se de ensaio clínico controlado, sem aleatorização (MOORE e col., 2000). Dois ensaios clínicos eram duplo-cegos (NEGRO e col., 2007; THOMSON e col., 2001), enquanto os demais foram cegos apenas para as participantes (DODGE e col., 1999; MOORE e col., 2000). 
Em todos os estudos foram avaliadas gestantes saudáveis, porém com baixa ingestão ou baixo estado nutricional relativo ao selênio, que receberam o mineral na forma de selenometionina, em doses que variavam de 50 a 200ug de selênio/dia. Contudo, os períodos de início da suplementação foram distintos nos quatro estudos, variando entre o segundo mês de gestação e o último trimestre gestacional e continuando durante o período de lactação. Essa diferença no tempo de início da suplementação poderia ser importante caso os estudos tivessem avaliado alguns desfechos em especial, particularmente aqueles relacionados ao desenvolvimento fetal, tais como a ocorrência de abortos e defeitos do tubo neural, que poderiam estar relacionados à deficiência de selênio ou ainda a uma perda do potencial antioxidante materno, refletido pela diminuição da atividade da glutationa peroxidase (BARRINGTON e col., 1996; DOBRZYNSKI e col., 1998; AL-KUNANI e col., 2001; DESAI e col., 2006).

A utilização de suplementos de selênio em sua forma orgânica, a selenometionina, parece apropriada, uma vez que as formas inorgânicas do mineral não são naturalmente presentes na dieta e sua metabolização ocorre de maneira distinta (ASHTON et al., 2009). Em adição, todas as doses empregadas podem ser consideradas seguras, trazendo mínimos riscos de ocorrência de selenose para as mulheres suplementadas, especialmente porque estas, em sua maioria, apresentavam baixa ingestão ou baixo estado nutricional do mineral. No entanto, percebe-se que os estudos não avaliam possíveis efeitos colaterais ou adversos decorrentes da intervenção, tendo a ocorrência destes sido relatada apenas no estudo de NEGRO e col. (2007).

Apesar dos estudos terem passado pelo crivo da qualidade metodológica, algumas de suas limitações precisam ser consideradas no planejamento de investigações futuras.

Nota-se ausência de descrição apropriada dos tratamentos utilizados nos grupos placebo, tendo sido apresentado apenas o do estudo de MOORE e col. (2000). É possível que os grupos placebo tenham recebido algum nutriente em dosagem mínima, e o não detalhamento prejudica o 
entendimento da intervenção e sua comparação, podendo inclusive interferir na inclusão ou não de estudos na revisão.

Durante a etapa de extração dos dados notou-se a ausência de medidas de frequência ou de incidência, médias, desvios-padrão ou intervalos de confiança de alguns desfechos relatados que, apesar de não fazerem parte dos objetivos principais dos estudos, poderiam ser relevantes para a avaliação dos efeitos da intervenção. Dentre esses podem-se destacar a ocorrência de hipertensão gestacional, de abortos, de ruptura prematura de placenta, de partos prematuros e ainda características como o peso ao nascer e o escore de APGAR. Contudo, entende-se que estudos de intervenção como aqueles incluídos nesta revisão, por serem conduzidos durante um considerável período de tempo (gestação e lactação) revestemse de grande complexidade. Desta forma, muitas variáveis precisam ser coletadas e, possivelmente por restrição de espaço, os autores podem optar pela apresentação parcial dos resultados, deixando de descrever aqueles referentes às variáveis para as quais não há significância estatística. Cabe ressaltar que esse fato não comprometeu o resultado da avaliação de qualidade metodológica, seja pela ferramenta da Cochrane Collaboration ou pela de DOWNS e BLACK (1998), visto que não se tratavam de desfechos principais.

Considerando-se a grande variabilidade observada nas concentrações de selênio em diversas populações e a ausência de pontos de corte para a avaliação do estado nutricional do mineral, torna-se primordial que os estudos sobre os efeitos de sua ingestão ou de sua suplementação avaliem e descrevam o estado nutricional relativo ao selênio no início e ao final da intervenção. Isso seria especialmente importante porque é possível supor que, dependendo do estado nutricional materno de selênio, a suplementação poderia ter diferentes impactos sobre a saúde da gestante e de seu bebê.

Dos três estudos que referiram ter avaliado gestantes com baixo estado nutricional relativo ao selênio ou baixa ingestão do mineral (DODGE e col. 1999; MOORE e col., 2000; THOMSON e col., 2001), apenas o de 
THOMSON e col. (2001) apresentou medidas ao início do estudo (concentrações plasmáticas e excreção urinária). DODGE e col. (1999), embora não tenham apresentado os valores obtidos, relatam que as concentrações plasmáticas de selênio mesmo das mulheres que receberam o placebo não eram indicativas de deficiência. NEGRO e col. (2007), apesar de realizarem a suplementação com selênio, em nenhum momento relatam o estado nutricional relativo ao mineral da população de estudo.

Ainda no que diz respeito à variabilidade no conteúdo de selênio dos alimentos e sua influência sobre o estado nutricional do mineral nas populações, poderia ser importante a avaliação do consumo alimentar das gestantes durante o período de intervenção, especialmente quando se tratar de estudos não aleatorizados. Diferenças na ingestão do mineral, se não apreciadas na análise dos dados, poderiam interferir na magnitude dos efeitos da suplementação. Somente DODGE e col. (1999) avaliaram o consumo dietético de selênio, por meio de um questionário de frequência alimentar, não tendo sido encontrada diferença estatística entre os grupos de intervenção.

Finalmente, outra questão a ser levantada refere-se ao uso de quaisquer suplementos nutricionais durante a gestação além do selênio. Os artigos em geral não relatam orientações às participantes quanto ao uso de outros suplementos que não fossem o da intervenção e não apresentam dados relativos a outros suplementos que são usualmente administrados no período gestacional, tais como sulfato ferroso e ácido fólico, ou ainda sobre o uso de multivitamínicos. 


\subsection{EFEITOS DA SUPLEMENTAÇÃO DE SELÊNIO NOS DESFECHOS RELACIONADOS À GESTANTE/PARTURIENTE}

\subsubsection{Ocorrência de morbidade materna}

A literatura sugere possíveis relações entre o baixo estado nutricional de selênio e condições tais como pré-eclampsia e diabetes gestacional. Além disso, por suas propriedades antioxidantes e sua atuação no sistema imunológico, seria possível levantar a hipótese de que o selênio poderia contribuir, mesmo que indiretamente, para a redução de outras condições de morbidade e até mesmo da mortalidade materna, tanto no período gestacional quanto no pós-parto.

No entanto, apenas o estudo de NEGRO e col. (2007) avaliou a ocorrência de morbidade materna após suplementação com selênio no período gestacional. Embora os autores relatem não ter havido diferenças na ocorrência de hipertensão e pré-eclampsia entre os grupos com e sem suplementação, o fato de medidas de ocorrência e de significância não terem sido apresentadas não permite que sejam tiradas conclusões quanto a esse desfecho. É preciso considerar, ainda, que o tamanho da amostra do estudo pode não ter sido suficiente para evidenciar diferenças estatisticamente significantes entre os grupos, especialmente porque a préeclampsia somente acomete até $10 \%$ das gestações (PÓVOA e col., 2008; KUKLINA e col., 2009; SRINIVAS e col., 2009). Dessa forma, seriam necessários mais estudos, com amostras maiores e que mensurassem não somente a ocorrência de hipertensão gestacional ou pré-eclampsia como desfecho, mas também os valores de pressão arterial, na medida em que a suplementação com selênio poderia não ter um impacto direto sobre a ocorrência dessas morbidades, mas poderia implicar em redução significativa dos valores médios de pressão arterial. 
Apesar de haver relatos de que pré-eclampsia está relacionada ao aumento do estresse oxidativo e à redução das concentrações corporais de selênio, é possível que intervenções com antioxidantes não sejam capazes de minimizar o estresse oxidativo e os desfechos gestacionais adversos a ele relacionados. Destaca-se que a revisão sistemática conduzida por RUMBOLD e col. (2008) não apontou evidências de benefício da suplementação com quaisquer antioxidantes durante a gestação sobre a ocorrência de pré-eclampsia, de nascimentos de crianças pequenas para a idade gestacional, de mortalidade da criança, de morbidade materna e neonatal ou ainda sobre o desenvolvimento da criança em longo prazo e a ocorrência de efeitos colaterais e eventos adversos.

Foram avaliados por NEGRO e col. (2007) desfechos relativos à ocorrência de hipotireoidismo materno em mulheres com anticorpos para a tireoidite autoimune. Durante a gestação, a suplementação reduziu significativamente esses anticorpos, mas não teve efeitos sobre o padrão de ecogenicidade da tireóide. Foram observadas diferenças na ocorrência de hipotireoidismo materno apenas quando considerado todo o período pósparto, ou seja, doze meses após o nascimento da criança. Tal efeito positivo pode ter sido decorrente não somente da suplementação com o mineral durante o período gestacional, mas também no período de lactação. Os autores acreditam que a ausência de diferenças estatísticas nas concentrações dos hormônios tireoidianos possa ser explicada pelo fato de que no início do tratamento as gestantes apresentavam concentrações sanguíneas de selênio adequadas ou muito próximas da adequação. Visto que a atividade da iodotironina deiodinase encontra-se reduzida apenas na deficiência severa de selênio, as gestantes poderiam ter apresentado um aumento na atividade antiinflamatória, porém sem afetar os hormônios tireoidianos. Apesar disso, os autores sugerem que os efeitos positivos da suplementação observados na gestação e no pós-parto sejam decorrentes do aumento da atividade da glutationa peroxidase, que reduziria o rebote imunológico nas mulheres com os anticorpos para a tireoidite autoimune. Destacam ainda algumas particularidades relativas aos efeitos da 
suplementação de selênio sobre os anticorpos estudados: a suplementação deve ser contínua, pois seus efeitos não são duradouros, e a redução dos anticorpos é dose-dependente, sendo necessárias doses maiores que $100 \mu \mathrm{g} /$ dia para que a atividade de glutationa peroxidase seja maximizada e ocorra a redução dos anticorpos para a tireoidite autoimune.

Os benefícios da suplementação de selênio sobre a produção de hormônios da tireóide, contudo, não estão bem esclarecidos. THOMSON e col. (2005) relatam os resultados de cinco estudos conduzidos por seu grupo de pesquisa em que foi avaliada a interação entre selênio e iodo, incluindo a relação entre o estado de selênio e a função tireoidiana e o efeito da suplementação com selênio sobre essa função. Em nenhum dos estudos os autores encontraram correlações estatisticamente significantes entre o estado de selênio, mensurado por meio das concentrações plasmáticas e sanguíneas do mineral e das atividades plasmática e sanguínea de glutationa peroxidase, e os marcadores de função tireoidiana, que incluíam as concentrações plasmáticas de $\mathrm{TSH}, \mathrm{T}_{4}$ e $\mathrm{T}_{3}$. Segundo eles, nos estudos em que foi realizada suplementação com selênio, não houve alterações significativas nas concentrações plasmáticas de $T_{4}$ e na razão $T_{3}: T_{4}$. Apenas

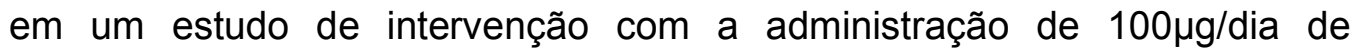
selenometionina em indivíduos fumantes houve redução significativa das concentrações de $\mathrm{T}_{4}$ em comparação ao grupo que recebeu placebo.

\subsubsection{Ocorrência de desfechos gestacionais adversos}

Apesar de ter sido sugerida na literatura uma relação entre o estado nutricional relativo ao selênio da gestante e desfechos gestacionais adversos tais como abortos, ocorrência de defeitos do tubo neural e de hérnia diafragmática congênita, baixo peso ao nascer e nascimentos prematuros, nota-se insuficiência de estudos que avaliem os efeitos da suplementação com o mineral sobre tais condições.

Somente o estudo de NEGRO e col. (2007) avaliou desfechos como abortos, ruptura prematura de placenta e partos prematuros, referindo que 
não houve diferenças entre o grupo de gestantes que receberam e as que não receberam suplementação de selênio. No entanto, assim como para a morbidade materna, os autores não referiram medidas de ocorrência e significância, o que impossibilita que sejam inferidas conclusões a respeito dos benefícios da intervenção.

Abortos e defeitos do tubo neural podem estar associados à diminuição da capacidade antioxidante e ao aumento do estresse oxidativo, mas nesse caso a relação de causa e efeito é desconhecida. Assim, o maior estresse oxidativo poderia ser uma consequência do processo, e baixas concentrações de selênio poderiam unicamente refletir a maior utilização do mineral para a produção de glutationa peroxidase numa tentativa de minimizar o estresse oxidativo. No que diz respeito à ocorrência de hérnia diafragmática congênita, foi encontrado apenas um estudo que investigou a relação entre esse desfecho e a ingestão de selênio (YANG e col., 2008). Na presença de uma relação entre a deficiência de selênio e a ocorrência de desfechos adversos, é possível que a suplementação com o mineral trouxesse benefícios somente se iniciada ainda no período periconcepcional.

Ao se estudar a relação entre o selênio e o baixo peso ao nascer, é primordial que se controle as análises estatísticas para a idade gestacional, pois uma vez que o nascimento pré-termo compromete a transferência de selênio da mãe para o feto, se recém-nascidos prematuros forem classificados como de baixo peso ao nascer, consequentemente apresentarão menores quantidades do mineral. Já no que tange à ocorrência de ruptura prematura de membrana, esta poderia ter uma relação com o aumento do estresse oxidativo (JOSHI e col., 2008; STEIN e col., 2008). Nessa situação, se a suplementação com selênio é capaz de reduzir o estresse, então poderia diminuir a ocorrência de partos prematuros, mas não há estudos que lancem luz a esse respeito. 
5.4.3 Ocorrência de efeitos colaterais à suplementação

Quanto à ocorrência de efeitos colaterais, a importância de sua avaliação justifica-se por algumas razões, dentre as quais: há situações em que o limiar entre o benefício e a segurança é muito próximo; outras em que tratamentos distintos podem ter efetividade semelhante, porém com diferentes perfis de risco, ou ainda situações em que um dado tratamento pode ser muito benéfico, mas seus efeitos adversos impedirem a sua continuidade (LOKE e col., 2007).

Dos quatro estudos incluídos nesta revisão, apenas o de NEGRO e col. (2007) analisou os efeitos colaterais como desfecho de interesse, contudo, não foram listados quais seriam esses os possíveis efeitos. A avaliação dos efeitos colaterais é de tamanha relevância que o CONSORT recomenda a sua descrição detalhada em todos os grupos de intervenção (MOHER e col., 2001).

LOKE e col. (2008) destacam que, para se avaliar a qualidade do relato dos efeitos colaterais, é preciso considerar se suas definições foram apresentadas, quais métodos foram utilizados para monitorar esses efeitos, se houve exclusão de pacientes da análise devido a efeitos colaterais, se os dados numéricos são apresentados para cada grupo de estudo e quais categorias de efeitos colaterais são relatadas pelos pesquisadores. É preciso considerar também que muitas vezes os efeitos colaterais de uma dada intervenção podem ser identificados apenas em longo prazo, ou ainda ser desconhecidos quando do planejamento do estudo.

Tendo em vista que revisões sistemáticas que não considerem os efeitos adversos de intervenções, enfatizando apenas os benefícios do tratamento, podem não fornecer informações suficientes para a tomada de decisões, fazendo com que as intervenções pareçam mais favoráveis do que de fato são (LOKE e col., 2007; LOKE e col., 2008), torna-se imprescindível que os estudos que avaliem efeitos de intervenções busquem relatar a ocorrência de tais desfechos. 


\subsubsection{Estado nutricional relativo ao selênio}

Nos estudos incluídos nesta revisão, o estado nutricional relativo ao selênio foi avaliado segundo as concentrações sanguíneas e plasmáticas do mineral, a excreção urinária de selênio e a atividade plasmática da glutationa peroxidase. Em todos os estudos, a suplementação com selênio melhorou o estado nutricional, independentemente do marcador utilizado, da dose da suplementação e do estado nutricional inicial. Assim, as mulheres que receberam suplementação apresentaram maiores concentrações de selênio e excreção urinária do mineral que as não suplementadas, mesmo nos momentos em que ocorre redução das concentrações do mineral (a partir do $6^{\circ}$ mês de gestação). Esse resultado era esperado, uma vez que os principais marcadores do estado nutricional de selênio, incluindo as concentrações plasmáticas e sanguíneas do mineral e a atividade de glutationa peroxidase, relacionam-se à sua ingestão (THOMSON e col., 2005).

É preciso ponderar, no entanto, que o fato de três estudos (NEGRO e col., 2007; THOMSON e col., 2001; MOORE e col., 2000) terem continuado a suplementação durante a lactação implica que o comportamento das concentrações de selênio nesse período não necessariamente se refere aos efeitos da intervenção durante a gestação.

A suplementação com selênio parece aumentar as concentrações plasmáticas e séricas do mineral, independentemente da redução observada no período gestacional (BUTLER e col., 1982), que poderia ser decorrente da hemodiluição, do transporte de selênio para o feto ou ainda da utilização do selênio para a produção de enzimas antioxidantes (FERRER e col., 1999; KANTOLA e col., 2004; MAKHOUL e col., 2004). Segundo THOMSON e col. (2001), o declínio das concentrações de selênio maternas ocorre independentemente da suplementação de selênio, e acompanha as mudanças que ocorrem no volume plasmático da gestação.

No que diz respeito à excreção urinária de selênio, esta se manteve constante em gestantes que não receberam suplementação, enquanto 
naquelas que são suplementadas a excreção aumentou até o segundo mês de suplementação, quando foi atingido um platô. Em todos os momentos, a excreção urinária de selênio foi maior em gestantes que receberam a suplementação.

A excreção de selênio se correlacionou com a taxa de filtração glomerular, mensurada por meio do clearance de creatinina e não estava relacionada à excreção de iodo (THOMSON e col., 2001). Apesar de os autores terem avaliado a relação entre a excreção urinária de selênio e de iodo, considerando-se que o papel do selênio na função tireoidiana reside na produção hormonal, não parece biologicamente plausível que houvesse qualquer relação entre esses minerais no que diz respeito à sua excreção. No entanto, em um artigo mais recente publicado pelo mesmo grupo de pesquisa, foram relatadas correlações positivas e estatisticamente significantes entre a excreção urinária de 24 de selênio e de iodo e entre as concentrações urinárias desses minerais em dois de cinco estudos: o primeiro avaliou adultos saudáveis recrutados em um centro de transfusão de sangue em Dunedin, Nova Zelândia, e o segundo tratou-se de um estudo de intervenção no qual indivíduos fumantes receberam suplementação com selenometionina (THOMSON e col., 2005).

Os resultados relativos à excreção urinária de selênio descritos por THOMSON e col. (2001), que encontraram maior excreção do mineral na urina de 24 horas de gestantes suplementadas quando comparadas a nãogestantes suplementadas, sugerem que durante a gestação ocorra uma maior perda do mineral e diferem daqueles do estudo clássico de SWANSON e col. (1983), que observaram redução da excreção do mineral durante a gestação.

De acordo com THOMSON e col. (2001), o maior volume de urina das gestantes não foi capaz de explicar a maior excreção de selênio, o que poderia ser em parte decorrente do aumento da taxa de filtração glomerular. Os autores sugerem ainda que outros fatores implicados na maior excreção de selênio poderiam ser o aumento da ingestão ou o aumento da massa magra observado durante a gestação. 
Embora a suplementação melhore significativamente o estado nutricional relativo ao selênio, como apontado especialmente pelo aumento das suas concentrações plasmáticas e séricas e pelo aumento da excreção urinária do mineral, pode-se questionar a relevância desse resultado em populações que não sejam deficientes, pois o simples aumento das concentrações do mineral ou da atividade da glutationa peroxidase pode não necessariamente refletir benefícios significativos sobre a saúde da mãe e da criança. Apesar disso, é conhecido que o estado de selênio sub-ótimo durante 0 terceiro trimestre de gestação pode resultar em baixas concentrações de selênio e atividade de glutationa peroxidase em recémnascidos (THOMSON e col., 2001).

Em uma revisão sistemática recentemente publicada por ASHTON e col. (2009) foi encontrado que a suplementação com selênio na forma orgânica (selenometionina ou levedura rica em selênio), assim como no presente estudo, aumenta significativamente as concentrações plasmáticas do mineral, mas com grande heterogeneidade entre os diferentes estudos. Com relação às concentrações sanguíneas de selênio, não foram localizados estudos com baixo risco de vieses que as avaliassem como biomarcador do estado nutricional do mineral em adultos saudáveis, enquanto para a atividade plasmática de glutationa peroxidase apenas um estudo apresentava baixo risco. Os autores destacam que apesar de o selênio plasmático se apresentar como um bom biomarcador do estado de selênio em diferentes situações, mais estudos ainda são necessários para avaliar a heterogeneidade das respostas à suplementação com o mineral, e que mais estudos precisam ser conduzidos para avaliar a utilidade da concentração sanguínea de selênio e da atividade plasmática de glutationa peroxidase como marcadores do seu estado nutricional.

Estudos recentes sugerem que a selenoproteína $P$ poderia ser um bom marcador funcional de selênio, pois representa cerca de metade do mineral no plasma, apresenta boa correlação com o selênio plasmático até cerca de $125 \mathrm{ng} / \mathrm{mL}$, tem maior sensibilidade que outras selenoproteínas (incluindo a glutationa peroxidase) tanto em situações de deficiência quanto 
após suplementação e parece responder de forma semelhante à ingestão de diferentes formas de selênio (FAIRWEATHER-TAIT, 2010).

\subsubsection{Marcadores de estresse oxidativo}

No estudo de MOORE e col. (2001), a suplementação de selênio no período gestacional reduziu significativamente as concentrações plasmáticas de TBARS, indicando uma redução do estresse oxidativo. Essa redução foi observada tanto no momento do parto, o que refletiria os efeitos da suplementação no período gestacional, quanto durante o período de lactação, quando a suplementação foi continuada. Essa redução das TBARS poderia ser explicada pelo aumento das concentrações plasmáticas de selênio e da atividade da glutationa peroxidase.

Apesar de as relações entre o estresse oxidativo e a ocorrência de morbidade materna e de desfechos gestacionais adversos anteriormente mencionados não estarem bem estabelecidas, pode-se supor que a diminuição da produção de radicais livres por meio do aumento da atividade antioxidante materna traria benefícios à mãe e ao bebê, mesmo que indiretamente. WEINBERGER e col. (2006) sugerem que a exposição aos radicais livres em excesso no período intrauterino pode ser um determinante da mortalidade e morbidade do recém-nascido pré-termo por doenças relacionadas aos radicais de oxigênio, que incluem hemorragia intraventricular, displasia broncopulmonar, enterocolite necrosante e retinopatia da prematuridade. Por esse motivo, destaca-se a necessidade de mais estudos que busquem evidências tanto dos efeitos da suplementação de selênio sobre uma variedade de marcadores do estresse oxidativo e não somente da glutationa peroxidase, mas também de que forma essa possível redução da produção de radicais livres beneficiaria gestantes/parturientes e, por conseguinte, seus recém-nascidos. 


\subsubsection{Concentrações de selênio no leite materno}

Da mesma forma que o conteúdo de selênio no solo se reflete no estado nutricional de selênio da mãe, influencia a concentração do mineral no recém-nascido e no leite materno. Assim, o conteúdo de selênio no leite humano pode apresentar grande variação de acordo com a região geográfica onde a mulher reside (ZACHARA e PILECKI, 2000; DANIELS e col., 2008).

Estudos já observaram que as concentrações de selênio e a atividade de glutationa peroxidase maternas têm correlação positiva e estatisticamente significante com as concentrações de selênio no leite materno (MANNAN e PICCIANO, 1987; WASOWICZ e col., 2001). Portanto, um aumento da concentração de selênio no leite materno poderia ser esperado como um provável efeito da suplementação.

Ambos os estudos que avaliaram as concentrações de selênio no leite materno (DODGE e col., 1999; MOORE e col., 2000) encontraram maiores níveis do mineral entre gestantes que foram suplementadas. Este resultado reveste-se de grande importância ao se considerar que durante alguns meses o leite materno é a única fonte de elementos-traço para a criança (WASOWICZ e col., 2001; HANNAN e col., 2005).

Em adição, especialmente em populações nas quais a ingestão do mineral é insuficiente, a sua suplementação desde a gestação poderia assegurar que a criança amamentada recebesse quantidade adequada de selênio. A suplementação poderia também ser relevante ao se considerar a possibilidade de nascimento prematuro e/ou de recém-nascido com muito baixo peso ao nascer que, além de apresentarem um comprometimento do estado nutricional relativo ao selênio e da atividade de glutationa peroxidase devido aos estoques reduzidos do mineral, podem apresentar uma menor absorção de selênio no início do desenvolvimento pós-natal aliada a um aumento de sua necessidade em decorrência do período de rápido crescimento que vivenciam (DISON e col., 1993; FRIEL e col., 1993; ALSALEH e col., 1998; ZACHARA e PILECKI, 2000). 
Segundo DODGE e col. (1999), o aumento da concentração de selênio no leite materno poderia ser decorrente de uma maior incorporação de selenometionina às proteínas, ao invés da metionina. Assim, a melhora do estado nutricional relativo ao selênio da mãe promovida pela suplementação, permitiria que as proteínas por ela produzidas e transferidas para o leite apresentem uma maior quantidade de selenometionina.

MOORE e col. (2000) referem que embora tenham observado aumento nas concentrações de selênio no leite materno de gestantes que receberam suplementação, a quantidade do mineral no colostro estava abaixo do que é considerado normal para mulheres com ingestão adequada de selênio $(40 \mu \mathrm{g} / \mathrm{L})$, e sugerem que a suplementação administrada possa não ter sido suficiente para corrigir o estado nutricional.

5.4.7 Atividade de glutationa peroxidase no leite materno

O único estudo que avaliou a atividade de glutationa peroxidase no leite materno foi o de DODGE e col. (1999), que não apresentou diferença entre os grupos que receberam ou não a suplementação de selênio. Esse resultado poderia ser explicado pela suposição dos autores de que o aumento da concentração de selênio no leite materno se deve à incorporação do mineral à metionina. Dessa forma, o aumento do conteúdo de selênio no leite materno não necessariamente implicaria uma maior atividade de glutationa peroxidase.

Contudo, assim como as concentrações plasmáticas de selênio maternas e a atividade plasmática de glutationa peroxidase materna correlacionam-se de forma positiva e estatisticamente significante com a concentração de selênio do leite materno, o mesmo parece ocorrer com a atividade da glutationa peroxidase (MANNAN e PICCIANO, 1987). Deste modo, mais estudos são necessários para se definir os efeitos da suplementação de selênio sobre a atividade de glutationa peroxidase no leite materno. 
Se de fato a suplementação contribuir para o aumento da atividade da enzima, podem-se levantar duas hipóteses: ela poderia contribuir para um melhor perfil de ácidos graxos no leite materno, como será exposto mais adiante, ou ainda beneficiar especialmente os recém-nascidos com baixo peso ao nascer que, por estarem expostos ao fenômeno da programação fetal, apresentariam maiores riscos futuros de doenças crônicas na vida adulta. Já foi amplamente sugerido que o estresse oxidativo causaria morte celular por apoptose e seria um dos mecanismos implicados na programação fetal, interagindo com os demais mecanismos, que incluem a alteração da expressão genética, a redução da proliferação celular secundária a deficiências nutricionais, mudanças nos receptores das superfícies celulares e a maturação do sistema imunológico por meio da via Th-2 (NESTERENKO e ALY, 2009).

\subsubsection{Perfil de ácidos graxos no leite materno}

Dos dois estudos que avaliaram o perfil de ácidos graxos no leite materno, somente o de DODGE e col. (1999) encontrou diferenças no grupo suplementado, que apresentou maiores concentrações de ácidos graxos mono e poliinsaturados e menores concentrações de ácidos graxos saturados. Essa mudança no perfil, contudo, não poderia ser explicada pela atividade da enzima antioxidante glutationa peroxidase, que não diferiu entre os grupos. Os autores destacam outras selenoenzimas antioxidantes que poderiam estar implicadas na proteção contra a oxidação das gorduras, ocasionando essa mudança do perfil lipídico do leite.

Por outro lado, MOORE e col. (2000), que não encontraram diferenças no perfil de ácidos graxos dos grupos com ou sem suplementação, sugerem que a baixa atividade da glutationa peroxidase observada em ambos os grupos não tenha sido suficiente para promover alterações significativas. Ainda segundo os autores, não há um consenso acerca da relação entre a atividade da glutationa peroxidase e a 
concentração de selênio do leite materno, sendo possível que outros fatores estejam implicados na atividade da enzima.

Mais estudos ainda são necessários a fim de se esclarecer o papel da suplementação de selênio tanto na atividade da glutationa peroxidase do leite materno quanto no perfil de ácidos graxos. Em relação ao aumento do conteúdo de ácidos graxos poliinsaturados, este poderia trazer importantes benefícios para o crescimento e desenvolvimento do recém-nascido. Este tipo de gordura, principalmente de cadeia longa, se acumula preferencialmente no cérebro e na retina, desempenhando um papel fundamental nas funções cognitiva e visual, no período pré e pós-natal, e está entre os nutrientes do leite materno essenciais para o desenvolvimento do sistema imunológico da criança (BOKOR e col., 2007; GANAPATHY, 2009).

Ademais, durante o primeiro ano de vida, mesmo a partir da introdução da alimentação complementar, o leite materno continua sendo a principal fonte de ácidos graxos poliinsaturados de cadeia longa para a criança (SCHWARTZ e col., 2010).

\subsection{EFEITOS DA SUPLEMENTAÇÃO DE SELÊNIO NOS DESFECHOS RELACIONADOS AO RECÉM-NASCIDO}

Embora um trabalho reporte a ausência de efeitos da suplementação sobre desfechos relativos ao recém-nascido (NEGRO e col., 2007), que incluíam o peso ao nascer e o escore de APGAR, não foram apresentadas as medidas resumo ou valores descritivos dos testes estatísticos para tais desfechos. Percebe-se que os estudos em geral, por terem como objetivos principais desfechos relativos à gestante, parturiente ou lactante, contribuem pouco para o entendimento da relação entre a suplementação de selênio durante a gestação e as condições de saúde do recém-nascido. 


\section{CONCLUSÕES}

As evidências científicas que compõem a presente revisão sistemática, que avaliou os efeitos da suplementação de selênio isolado no período gestacional, baseiam-se em quatro estudos de intervenção. Esses estudos apresentam tamanhos amostrais pequenos e foram conduzidos com populações bem específicas: três avaliaram a suplementação em gestantes com ingestão inadequada e baixo estado nutricional do mineral, enquanto um compreendeu mulheres com anticorpos para tireoidite autoimune.

Nesse contexto, é possível afirmar que não existem evidências robustas acerca dos efeitos dessa intervenção durante a gestação. Os desfechos mais consistentes apontados por esse trabalho, que são o aumento das concentrações plasmáticas e séricas de selênio e das concentrações do mineral no leite materno a partir da suplementação, podem ser questionáveis, no sentido de que é desconhecido se tais mudanças promoveriam benefícios à saúde da mãe e/ou do recém-nascido.

Assim sendo, identifica-se a necessidade de mais estudos, com elevada qualidade metodológica, populações menos específicas e maiores tamanhos amostrais, para que se estabeleçam quais seriam de fato os efeitos da suplementação de selênio na morbimortalidade materna e do recém-nascido. Além disso, ressalva-se a importância da atualização periódica das revisões sistemáticas na medida em que mais estudos sobre o seu tema forem publicados, agregando-lhe novas evidências e eventualmente contribuindo para mudanças em seus resultados e conclusões. 


\section{REFERÊNCIAS}

AL-KUNANI, A. S. et al. The selenium status of women with a history of recurrent miscarriage. British Journal of Obstetrics and Gynaecology, v. 108, n. 10, p. 1094-1097, out. 2001.

ALLEN, L.H. Multiple micronutrients in pregnancy and lactation: an overview. The American Journal of Clinical Nutrition, v. 81, s. 1, p.1206S-1212S, mai. 2005.

AL-SALEH, I. et al. Serum selenium levels in Saudi newborns. International Journal of Environmental and Health Research, v. 8, n. 4, p. 269-275, dez. 1998

ARTHUR, J.; McKENZIE, R. C.; BECKETT, G. J. Selenium in the immune system. The Journal of Nutrition, v. 133, n. 5, s. 1, p. 1457S-1459S, mai. 2003.

ASHTON, K. et al. Methods of assessment of selenium status in humans: a systematic review. American Journal of Clinical Nutrition, v. 89, s. 6, p. 2025S-2039S, jun. 2009.

BARRINGTON, J. W. et al. Selenium deficiency and miscarriage: a possible link? British Journal of Obstetrics and Gynaecology, v. 103, n. 2, p. 130132, fev. 1996.

BATTELL, M. L.; DELGATTY, H. L. M.; McNEILL, J. H. Sodium selenate corrects glucose tolerance and heart function in STZ diabetic rats. Molecular and Cellular Biochemistry, v. 179, n. 1-2, p. 27-34, fev. 1998.

BERLIN, J.A.; RENNIE, D. Measuring the quality of trials: the quality of quality scales. Journal of the American Medical Association (JAMA), v.282, n.11, p.1083-1085, set. 1999.

BIRI, A. et al. Oxidant status in maternal and cord plasma and placental tissue in gestational diabetes. Placenta, v. 27, n. 2-3, p. 327-332, fev./mar. 2006.

BLACK, R. E. Micronutrients in pregnancy. British Journal of Nutrition, v. 85, s. 2, p. S193-S197, mai. 2001.

BO, S. et al. Gestational hyperglycemia, zinc, selenium, and antioxidant vitamins. Nutrition, v. 21, n. 2, p.186-191, fev. 2005.

BOGDEN, J.D. et al. Low-normal serum selenium early in human pregnancy predicts lower birth weight. Nutrition Research, v. 26, n. 10, p. 497-502, out. 2006. 
BOKOR, S.; KOLETZKO, B.; DECSI, T. Systematic review of fatty acid composition of human milk from mothers of preterm compared to full-term infants. Annals of Nutrition \& Metabolism, v. 51, n. 6, p. 550-556, 2007.

BRO, S. et al. Serum selenium concentration in maternal and umbilical cord blood. Relation to course and outcome of pregnancy. Journal of Trace Elements and Electrolytes in Health and Disease, v. 2, n. 3, p. 165-169, set. 1988.

BUTLER, J. A.; WHANGER, P. D.; TRIPP, M. J. Blood selenium and glutathione peroxidase activity in pregnant women: comparative assays in primates and other animals. American Journal of Clinical Nutrition, v. 36, n. 1, p. 15-23, jul. 1982.

CENGIZ, B. et al. Serum zinc, selenium, copper, and lead levels in women with second-trimester induced abortion resulting from neural tube defects. Biological Trace Element Research, v. 97, n. 3, p. 225-235, mar. 2004.

CHAMY, V.M. et al. Oxidative stress is closely related to clinical severity of pre-eclampsia. Biological Research, v. 39, n. 2, p. 229-236, jul. 2006.

DANIELS, L. et al. Selenium status of term infants fed seleniumsupplemented formula in a randomized dose-response trial. American Journal of Clinical Nutrition, v. 88, n. 1, p. 70-76, jul. 2008.

DAWSON, E. B.; EVANS, D. R.; NOSOVITCH, J. Third-trimester amniotic fluid metal levels associated with preeclampsia. Archives of Environmental Health, v.54, n.6, p. 412-415, nov./dez. 1999.

DE WEERD, S. et al. Preconception nutritional intake and lifestyle factors: first results of an explorative study. European Journal of Obstetrics \& Gynecology and Reproductive Biology, v. 111, n. 2, p. 167-172, dez. 2003.

DENNERY, P.A. Effects of oxidative stress on embryonic development. Birth Defects Research (Part C), v. 81, n. 3, p. 155-162, set. 2007.

DERBYSHIRE, E. et al. Habitual micronutrient intake during and after pregnancy in Caucasian Londoners. Maternal and Child Nutrition, v. 5, n. 1, p. 1-9, jan. 2009.

DESAI, P. et al. Selenium levels and glutathione peroxidase activity in spontaneous inevitable abortion. The Journal of Obstetrics and Gynecology of India, v. 56, n. 4, p. 311-314, jul./ago. 2006.

DISON, P. J. et al. Influence of maternal factors on cord and neonatal plasma micronutrient levels. American Journal of Perinatology, v. 10, n. 1, p. 3035, jan. 1993. 
DOBRZYNSKI, W. et al. Decreased selenium concentration in maternal and cord blood in preterm compared with term delivery. Analyst, v. 123, n. 1, p. 93-97, jan. 1998.

DOWNS, S. H.; BLACK, N. The feasibility of creating a checklist for the assessment of the methodological quality both of randomised and nonrandomised studies of health care interventions. Journal of Epidemiology and Community Health, v. 52, n. 6, p. 377-384, jun. 1998.

EGGER, M.; SMITH, G. D.; SCHNEIDER, M. Systematic reviews of observational studies. In: EGGER, M.; SMITH, G. D.; ALTMAN, D. G. Systematic reviews in health care. Meta-analysis in context. Londres: BMJ Books, 2006. cap. 12, p. 211-227.

EICHHOLZER, M. Micronutrient deficiencies in Switzerland: causes and consequences. Journal of Food Engineering, v. 56, n. 2-3, p. 171-179, fev. 2003.

FAIRWEATHER-TAIT, S. J.; COLLINGS, R.; HURST, R. Selenium bioavailability: current knowledge and future research requirements.

American Journal of Clinical Nutrition, v. 91, n. 5, p. 1484S-1491S, maio 2010.

FALL, C. H. et al. Micronutrients and fetal growth. The Journal of Nutrition, v. 133 , n. 5 (s.2), p. 1747S-1756S, mai. 2003.

FERRER, E. et al. Whole blood selenium content in pregnant women.

Science of the Total Environment, v. 227, n. 2-3, p. 139-143, mar. 1999.

FINLEY, J. W. Bioavailability of selenium from foods. Nutrition Reviews, v. 64, n. 3, p.146-151, mar. 2006.

FLOHÉ, L. Selenium in mammalian spermiogenesis. Biological Chemistry, v. 388, n. 10 , p. $987-995$, out. 2007.

FORCEVILLE, X. Seleno-enzymes and seleno-compounds: the two faces of selenium. Critical Care, v. 10, n. 6, p. 180, dez. 2006.

FRIEL, J. K. et al. Selenium status of very low birth weight infants. Pediatric Research, v. 34, n. 3, p. 293-296, set. 1993.

GANAPATHY, S. Long chain polyunsaturated fatty acids and immunity in infants. Indian Pediatrics, v. 46, n. 9, p. 785-790, set. 2009.

GLENVILLE, M. Nutritional supplements in pregnancy: commercial push or evidence based? Current Opinion in Obstetrics and Gynecology, v. 18, n. 6, p. 642-647, dez. 2006.

GRISSA, O. et al. Antioxidant status and circulating lipids are altered in human gestational diabetes and macrosomia. Translational Research, $v$. 150, n. 3, p. 164-171, set. 2007. 
GROMADZINSKA, J. et al. Selenium levels, thiobarbituric acid-reactive substance concentrations and glutathione peroxidase activity in the blood of women with gestosis and imminent premature labour. Analyst, v.123, n. 1, p. 35-40, jan. 1998.

GYAMFI, C.; WAPNER, R. J.; D'ALTON, M. E. Thyroid dysfunction in pregnancy. The basic science and clinical evidence surrounding the controversy in management. Obstetrics and Gynecology, v. 113, n. 3, p. 702-707, mar. 2009.

HAIDER, B. A.; BHUTTA, Z. A. Multiple-micronutrient supplementation for women during pregnancy. Cochrane Database of Systematic Reviews, v.18, n.4, out. 2006.

HANNAN, M. A. et al. Copper, selenium, and zinc concentrations in human milk during the first three weeks of lactation. Biological Trace Element Research, v. 107, n. 1, p. 11-20, out. 2005.

HAWKES, W. C.; ALKAN, Z.; LANG, K.; KING, J. C. Plasma selenium decrease during pregnancy is associated with glucose intolerance.

Biological Trace Element Research, v. 100, n. 1, p. 19-29, jul. 2004.

HEART, E.; SUNG, C. K. Insulin-like and non-insulin-like selenium actions in 3T3-L1 adipocytes. Journal of Cellular Biochemistry, v. 88, n. 4, p. 719731, mar. 2003.

HIGGINS, J. P. T.; GREEN, S. Cochrane Handbook for Systematic Reviews of Interventions Versão 5.0.0 [atualizada em Fev. 2008]. The Cochrane Collaboration, 2008. Disponível em: www.cochrane-handbook.org. Acesso em: 10 mar 2008.

HIGGINS, J.P.T.; GREEN, S. (editors). Cochrane Handbook for systematic reviews of interventions 4.2.5. [Updated May 2005]. In: The Cochrane Library, Issue 3, 2005. Chichester, UK: John Wiley \&Sons, Ltd.

HOFFMANN, P.R.; BERRY, M.J. The influence of selenium on immune responses. Molecular Nutrition \& Food Research, v. 52, n. 11, p. 12731280, nov. 2008.

HOLBEN, D.H.; SMITH, A. M. The diverse role of selenium within selenoproteins: a review. Journal of the American Dietetic Association, v. 99, n. 7, p.836-843, jul. 1999.

HOLMES, V.A.; McCANCE, D.R. Could antioxidant supplementation prevent pre-eclampsia? Proceedings of the Nutrition Society, v. 64, n. 4, p. 491501, nov. 2005.

HONG, J. et al. Association of antioxidant vitamins and oxidative stress levels in pregnancy with infant growth during the first year of life. Public Health Nutrition, v. 11, n. 10, p. 998-1005, out. 2007. 
INSTITUTE OF MEDICINE. Dietary reference intakes for vitamin C, vitamin E, selenium and carotenoids: a report of the Panel on Dietary Antioxidants and Related Compounds, Subcommittees on Upper Reference Levels of Nutrients and of Interpretation and Use of Dietary Reference Intakes, and the Standing Committee on the Scientific Evaluation of Dietary Reference Intakes, Food and Nutrition Board, Institute of Medicine. Washington D.C.: National Academy Press, 2000.

JADAD, A.; MOHER, D.; KLASSEN, T.P. Guides for reading systematic reviews: II. How did the authors find the studies and assess their quality? Archives of Pediatrics and Adolescent Medicine, v.152, n.8, p.812-817, ago. 1998.

JANIAUX, E.; POSTON, L.; BURTON, G. J. Placental-related diseases of pregnancy: involvement of oxidative stress and implications in human evolution. Human Reproduction Update, v. 12, n. 6, p. 747-755, nov./dez. 2006.

JOANNA BRIGGS INSTITUTE. Reviewer's manual. Adelaide: Joanna Briggs Institute, 2008.

JOSHI, S. R. et al. High maternal plasma antioxidant concentrations associated with preterm delivery. Annals of Nutrition \& Metabolism, v. 53, n. 3-4, p. 276-282, 2008.

JÜNI, P.; ALTMAN, D. G.; EGGER, M. Assessing the quality of controlled clinical trials. British Medical Journal, v. 323, n. 7303, p. 42-6, jul. 2001.

KANTOLA, M. et al. Selenium in pregnancy: is selenium an active defective ion against environmental chemical stress? Environmental Research, v. 96, n. 1, p. 51-61, set. 2004.

KAROWICZ-BILINKSA, A.; KEDZIORA-KORNATOWSKA, K.; BARTOSZ, G. Indices of oxidative stress in pregnancies with fetal growth restriction. Free Radical Research, v. 41, n. 8, p. 870-873, ago. 2007.

KILINC, M. et al. Evaluation of serum selenium levels in Turkish women with gestational diabetes mellitus, glucose intolerants, and normal controls.

Biological Trace Element Research, v. 123, n. 1-3, p. 35-40, fev. 2008.

KLASSEN, T. P.; JADAD, A. R.; MOHER, D. Guides for reading and interpreting systematic reviews. I. Getting started. Archives of Pediatrics and Adolescent Medicine, v. 152, n. 7, p.700-704, jul. 1998.

KÖHRLE, J. Selenium and the control of thyroid hormone metabolism. Thyroid, v. 15, n. 8, p. 841-853, ago. 2005.

KOKLU, E. et al. The relationship between birth weight, oxidative stress and bone mineral status in newborn infants. Journal of Paediatrics and Child Health, v. 43, n. 10, p. 667-672, out. 2007. 
KUKLINA, E. V.; AYALA, C.; CALLAGHAN, W. M. Hypertensive disorders and severe obstetric morbidity in the United States. Obstetrics and Gynecology, v. 113, n. 6, p. 1299-1306, jun. 2009.

KUPKA, R. et al. Selenium status is associated with accelerated HIV disease progression among HIV-1-infected pregnant women in Tanzania. Journal of Nutrition, v. 134, n. 10, p. 2556-2560, out. 2004.

KUPKA, R. et al. Effect of selenium supplements on hemoglobin concentration and morbidity among HIV-1-infected Tanzanian women. Clinical Infectious Diseases, v. 48, n. 10, p. 1475-1478, mai. 2009.

KUPKA, R. et al. Randomized, double-blind, place-controlled trial of selenium supplements among HIV-infected pregnant women in Tanzania: effects on maternal and child outcomes. The American Journal of Clinical Nutrition, v. 87 , n. 6 , p. $1802-1808$, jun. 2008.

KUPKA, R. et al. Selenium status, pregnancy outcomes, and mother-to-child transmission of HIV. Journal of Acquired Immune Deficiency Syndromes, v. 39, n. 2, p. 203-210, jun. 2005.

LAUPACIS, A.; STRAUS, S. Systematic reviews: time to address clinical and policy relevance as well as methodological rigor. Annals of Internal Medicine, v.147, n. 4, p. 273-274, ago. 2007.

LEI, X.G.; CHENG, W.H.; McCLUNG, J.P. Metabolic regulation and function of glutathione peroxidase-1. Annual Review of Nutrition, v. 27, p. 41-61, ago. 2007.

LOKE, Y. K.; PRICE, D.; HERXHEIMER, A. Chapter 14: Adverse effects. In: HIGGINS, J.P.T.; GREEN, S. (org.). Cochrane Handbook for Systematic Reviews of Interventions. Version 5.0.1 [updated September 2008]. The Cochrane Collaboration, 2008. Disponível em: www.cochrane-handbook.org.

LOKE, Y. K.; PRICE, D.; HERXHEIMER, A. Systematic reviews of adverse effects: framework for a structured approach. BMC Medical Research Methodology, v. 7, p. 1-9, jul. 2007.

LONGINI, M. et al. Association between oxidative stress in pregnancy and preterm premature rupture of membranes. Clinical Biochemistry, v. 40, n. 11, p. 793-797, jul. 2007.

LUO, Z.C. et al. Tracing the origins of "fetal origins" of adult diseases: programming by oxidative stress? Medical Hypotheses, v.66, n.1, p.38-44, fev. 2006.

MAKHOUL, I. R. et al. Selenium concentrations in maternal and umbilical cord blood at 24-42 weeks of gestation: basis for optimization of selenium supplementation to premature infants. Clinical Nutrition, v. 23 , n. 3, p. 373381, jun. 2004. 
MALLEN, C.; PEAT, G.; CROFT, P. Quality assessment of observational studies is not commonplace in systematic reviews. Journal of Clinical Epidemiology, v.59, n. 8, p.765-769, ago. 2006.

MANNAN, S.; PICCIANO, F. Influence of maternal selenium status on human milk selenium concentration and glutathione peroxidase activity. American Journal of Clinical Nutrition, v. 46, n. 1, p. 95-100, jul. 1987.

MATHEWS, F.; NEIL, H. A. W. Nutrient intakes during pregnancy in a cohort of nulliparous women. Journal of Human Nutrition and Dietetics, v. 11, n. 2, p. 151-161, abr. 1998.

McLACHLAN, S. K. et al. Dietary and biochemical selenium status of urban 6- to 24-month-old South Island New Zealand children and their postpartum mothers. The Journal of Nutrition, v. 134, n. 12, p. 3290-3295, dez. 2004.

MEHENDALE, S. et al. Fatty acids, antioxidants, and oxidative stress in preeclampsia. International Journal of Gynaecology and Obstetrics, v. 100, n. 3, p. 234-238, mar. 2008.

MENTRO, A. M.; SMITH, A.; MOYER-MILEUR, L. Plasma and erythrocyte selenium and glutathione peroxidase activity in preterm infants at risk for bronchopulmonary dysplasia. Biological Trace Element Research, v. 106, n. 2, p. 97-106, ago. 2005.

MICETIC-TURK, D. et al. Maternal selenium status in Slovenia and its impact on the selenium concentration of umbilical cord serum and colostrum.

European Journal of Clinical Nutrition, v. 54, n. 6, p. 522-524, jun. 2000.

MIHAILOVIĆ, M. et al. Selenium and malondialdehyde content and glutathione peroxidase activity in maternal and umbilical cord blood and amniotic fluid. Biological Trace Element Research, v. 73, n. 1, p. 47-54, jan. 2000.

MISTRY, H. D. et al. Reduced selenium concentrations and glutathione peroxidase activity in preeclamptic pregnancies. Hypertension, v. 52, n. 5, p. 881-888, nov. 2008.

MOHER, D. et al. Epidemiology and reporting characteristics of systematic reviews. PLoS Medicine, v. 4, n. 3, p. 448-455, mar. 2007.

MOHER, D.; SCHULZ, K. F.; ALTMAN, D. G. The CONSORT statement: revised recommendations for improving the quality of reports of parallel group randomized trials. JAMA, v. 285, n. 15, p. 1987-1991, abr. 2001. 
MOLNAR, J. et al. Serum selenium concentrations correlate significantly with inflammatory biomarker high-sensitive CRP levels in Hungarian gestational diabetic and healthy pregnant women at mid-pregnancy. Biological Trace Element Research, v. 121, n. 1, p. 16-22, jan. 2008.

MOORE, M. A. et al. Selenium supplementation of Chinese women with habitually low selenium intake increases plasma selenium, plasma glutathione peroxidase activity, and milk selenium, but not milk glutathione peroxidase activity. The Journal of Nutritional Biochemistry, v. 11, n. 6, p. 341-347, jun. 2000.

MORENO-REYES, R. et al. Kashin-Beck osteoarthropathy in rural Tibet in relation to selenium and iodine status. The New England Journal of Medicine, v. 339, n. 16, p. 1112-1120, out.1998.

MUKHERJEE, B. et al. Novel implications of the potential role of selenium on antioxidant status in streptozotocin-induced diabetic mice. Biomedicine \& Pharmacotherapy, v. 52, n. 2, p. 89-95, 1998.

NAVARRO-ALARCON, M.; CABRERA-VIQUE, C. Selenium in food and the human bod: a review. The Science of the Total Environment, v. 400, n. 13, p. 115-141, ago. 2008.

NEGRO, R. et al. The influence of selenium supplementation on postpartum thyroid women with thyroid peroxidase autoantibodies. The Journal of Clinical Endocrinology \& Metabolism, v. 92, n. 4, p. 1263-1268, abr. 2007.

NESTERENKO, T. H.; ALY, H. Fetal and neonatal programming: evidence and clinical implications. American Journal of Perinatology, v. 26, n. 3, p. 191-198, mar. 2009.

NICHOLS, J. A. A. et al. A survey to estimate total nutrient intake at conception - dietary and supplementary. Journal of Nutritional \& Environmental Medicine, v. 17, n. 1, p. 12-43, mar. 2008.

ODLAND, J. O. et al. Concentrations of essential trace elements in maternal serum and the effect on birth weight and newborn body mass index in subarctic and arctic populations of Norway and Russia. Acta Obstetricia et Gynecologica Scandinavica, v. 78, n. 7, p. 605-614, ago. 1999.

OLIVEIRA, N. S.; OLIVEIRA, J. M.; BERGAMASCHI, D. P. Concordância entre avaliadores na seleção de artigos em revisões sistemáticas. Revista Brasileira de Epidemiologia, v. 9, n. 3, p. 309-315, 2006.

ORHAN, H. et al. Circulating biomarkers of oxidative stress in complicated pregnancies. Archives of Gynecology and Obstetrics, v. 267, n. 4, p. 189195, fev. 2003. 
PAPP, L. V. et al. From selenium to selenoproteins: synthesis, identity, and their role in human health. Antioxidants and Redox Signalling, v. 9, n. 7, 2007.

PAPPAS, A.C. et al. Selenoproteins and maternal nutrition. Comparative Biochemistry and Physiology. Part B, Biochemistry and Molecular Biology, v. 151, n. 4, p. 361-372, dez. 2008.

PARKE, D. V. Nutritional antioxidants and disease prevention: mechanisms of action. In: BASU, T.K. et al. (Org.). Antioxidants in human health and disease. New York: CABI Publishing, 1999. p.1-11

PERONA, G. et al. Neonatal erythrocyte glutathione peroxidase deficiency as a consequence of selenium imbalance during pregnancy. British Journal of Haematology, v. 42, n. 4, p. 567-574, ago. 1979.

PETERS, J. L. et al. Comparison of two methods to detect publication bias in meta-analysis. Journal of the American Medical Association (JAMA), v. 295, n.6, p. 676-680, fev. 2006.

PINHEIRO, M. C. et al. Mercury and selenium concentrations in hair samples of women in fertile age from Amazon riverside communities. The Science of the Total Environment, v. 349, n. 1-3, p. 284-288, out. 2005.

PÓVOA, A. M. et al. Prevalence of hypertension during pregnancy in Portugal. Hypertension in Pregnancy, v. 27, n. 3, p. 279-284, 2008.

RAVN-HAREN G. et al. A short term intervention trial with selenate, selenium-enriched yeast and selenium-enriched milk: effects on oxidative defence regulation. British Journal of Nutrition, v. 99, n. 4, p. 883-892, abr. 2008.

RAYMAN, M. P. The importance of selenium to human health. Lancet, v. 356, n. 9225, p. 233-241, jul. 2000

RAYMAN, M. P.; BODE, P.; REDMAN, C. W. G. Low selenium status is associated with the occurrence of pregnancy disease preeclampsia in women from the United Kingdom. American Journal of Obstetrics and Gynecology, v. 189, n. 5, p.1343-1349, nov. 2003.

REYES, H. et al. Selenium, zinc and copper plasma levels in intrahepatic cholestasis of pregnancy, in normal pregnancies and in healthy individuals, in Chile. Journal of Hepathology, v. 32, n. 4, p. 542-549, abr. 2000.

RUMBOLD, A. Antioxidants for preventing pre-eclampsia. Cochrane Database of Systematic Reviews, (1):CD004227, jan. 2008.

SANDSTROM, B. Toxicity considerations when revising the Nordic Nutrition Recommendations. The Journal of Nutrition, v. 128, s. 2, p. 372S-374S, fev. 1998. 
SCHRAUZER, G. N. Nutritional selenium supplements: product types, quality, and safety. Journal of the American College of Nutrition, v. 20, n. 1, p. 1-4, fev. 2001.

SCHWARTZ, J. et al. PUFA and LC-PUFA intake during the first year of life: can dietary practice achieve a guideline diet? European Journal of Clinical Nutrition, v. 64, n. 2, p. 124-130, fev. 2010.

SILVA FILHO, C. R. et al. Assessment of clinical trial quality and its impact on meta-analyses. Revista de Saúde Pública, v.39, n.6, p. 865-873, dez. 2005.

SRINIVAS, S. K. et al. Rethinking IUGR in preeclampsia: dependent or independent of maternal hypertension? Journal of Perinatology, v. 29, n. 10 , p. $680-684$, out. 2009.

STAPLETON, S. R. Selenium: an insulin-mimetic. Cellular and Molecular Life Sciences, v. 57, n. 13-14, dez. 2000.

STEIN, T. P. et al. Oxidative stress early in pregnancy and pregnancy outcome. Free Radical Research, v. 42, n. 10, p. 841-848, out. 2008.

STERNE, J. A. C.; EGGER, M.; SMITH, G. D. Systematic reviews in healthcare: investigating and dealing with publication and other biases in meta-analysis. British Medical Journal, v. 323, n. 7304, p.101-105, jul. 2001.

STONE, G. W.; POCOCK, S. J. Randomized trials, statistics, and clinical inference. Journal of the American College of Cardiology, v. 55, n. 5, p. 428-431, fev. 2010.

SURAPANENI, K. M. Oxidant-antioxidant status in gestational diabetes patients. Journal of Clinical and Diagnostic Research, v. 1, n. 4, p. 235238, ago. 2007.

SWANSON, C. A. Quantitative and qualitative aspects of selenium utilization in pregnant and nonpregnant women: an application of stable isotope methodology. The American Journal of Clinical Nutrition, v. 38, n. 2, p. 169-180, ago. 1983.

TAN, M. et al. Changes of serum selenium in pregnant women with gestational diabetes mellitus. Biological Trace Element Research, v. 83, n. 3, p. 231-237, dez. 2001.

TAPIERO, H.; TOWNSEND, D.M.; TEW, K,D. The antioxidant role of selenium and seleno-compounds. Biomedicine \& Pharmacotherapy, v. 57, n. 3-4, p.134-144, mai./jun. 2003.

TASTEKIN, A. et al. Oxidative stress in infants born to preeclamptic mothers. Pediatrics International, v. 47, n. 6, p. 658-662, dez. 2005. 
The Plos Medicine Editors. Many reviews are systematic but some are more transparent and completely reported than others. PLoS Med 4(3);e147.

THOMSON, C. D. Assessment of requirements for selenium and adequacy of selenium status: a review. European Journal of Clinical Nutrition, v. 58, n. 3, p. 391-402, mar. 2004.

THOMSON, C. D. et al. The effect of selenium on thyroid status in a population with marginal selenium and iodine status. British Journal of Nutrition, v.94, n. 6, p. 962-968, dez. 2005.

VANDENBROUCKE, J. P. et al. Strengthening the reporting of observational studies in epidemiology (STROBE): explanation and elaboration. Annals of Internal Medicine, v. 147, n. 8, p. W163-W194, out. 2007.

VERIT, F. F. et al. Oxidative stress is associated with clinical severity of nausea and vomiting of pregnancy. American Journal of Perinatology, $v$. 24, n. 9, p. 545-548, out. 2007.

VON ELM, E. et al. Strengthening the reporting of observational studies in epidemiology (STROBE) statement: guidelines for reporting observational studies. Lancet, v. 370, n. 9596, p. 1453-1457, out. 2008.

WASOWICZ, W. et al. Selenium status of low-selenium area residents: Polish experience. Toxicology Letters, v. 137, n. 1-2, p. 95-101, jan. 2003.

WASOWICZ, W. et al. Selenium, zinc, and copper concentrations in the blood and milk of lactating women. Biological Trace Element Research, v. 79, n. 1, p. 221-233, mar. 2001.

WEINBERGER, B. et al. Lipid peroxidation in cord blood and neonatal outcome. Pediatrics International, v. 48, n. 5, p. 479-483, out. 2006.

YANG, W. et al. Nutrient intakes in women and congenital diaphragmatic hernia in their offspring. Birth Defects Research. Part A, Clinical and Molecular Teratology, v. 82, n. 3, p. 131-138, mar. 2008.

ZACHARA, B. A.; PILECKI, A. Selenium concentration in the milk of breastfeeding mothers and its geographic distribution. Environmental Health Perspectives, v. 108, n. 11, p. 1043-1046, nov. 2000.

ZENG, J.; ZHOU, J.; HUANG, K. Effect of selenium on pancreatic proinflammatory cytokines in streptozotocin-induced diabetic mice. Journal of Nutritional Biochemistry, v. 20, n. 7, p. 530-536, jul. 2009.

ZHENG, H. T. et al. Selenium inhibits high glucose- and high insulin-induced adhesion molecule expression in vascular endothelial cells. Archives of Medical Research, v. 39, n. 4, p. 373-379, mai. 2008. 


\section{APÊNDICE 1}

Avaliador: Data:

\section{Formulário de Avaliação de Resumo}

\begin{tabular}{|l|l|l|l|l|}
\hline Critérios de Inclusão & Sim & Não & $\begin{array}{c}\text { Não } \\
\text { claro }\end{array}$ & $\begin{array}{c}\text { Não } \\
\text { menciona }\end{array}$ \\
\hline $\begin{array}{l}\text { Foram avaliadas gestantes saudáveis ou não } \\
\text { saudáveis, em qualquer faixa etária, } \\
\text { independentemente do seu estado nutricional de } \\
\text { selênio? }\end{array}$ & & & & \\
\hline $\begin{array}{l}\text { Foi realizada intervenção nutricional durante o } \\
\text { período gestacional com suplementação de selênio } \\
\text { isolado, independentemente dos compostos, da } \\
\text { dosagem, da via de administração e do início e } \\
\text { duração da terapia? }\end{array}$ & & & & \\
\hline $\begin{array}{l}\text { Foi incluído grupo de comparação (controle) } \\
\text { recebendo placebo ou nenhuma intervenção? }\end{array}$ & & & & \\
\hline $\begin{array}{l}\text { Este estudo se trata de um ensaio clínico, um estudo } \\
\text { aleatorizado com conglomerados, um estudo de } \\
\text { coorte ou um caso-controle? }\end{array}$ & & & & \\
\hline
\end{tabular}

\section{Resultado:}

\begin{tabular}{|l|l|l|l|}
\cline { 2 - 4 } \multicolumn{1}{l|}{} & Sim & Não & $\begin{array}{c}\text { Não } \\
\text { claro }\end{array}$ \\
\hline Este trabalho deve ser selecionado para leitura na integra? & & & \\
\hline
\end{tabular}


ANEXO 1

Checklist para Avaliação da Qualidade de Estudos do tipo Ensaios Clínicos Aleatorizados Controlados

Cochrane Collaboration (tradução livre)

\begin{tabular}{|l|l|}
\hline Revisor: & Data: \\
\hline \multicolumn{2}{|l|}{} \\
\hline Autor: & Ano de publicação: \\
\hline Periódico: & N$^{\circ}$ de Registro: \\
\hline
\end{tabular}

Viés de seleção (aleatorização)

O processo de alocação dos participantes foi aleatório?

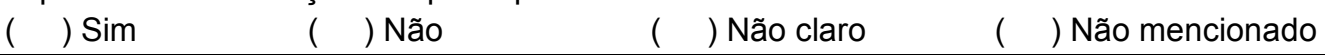

\section{Viés de desempenho (sigilo de alocação)}

Os participantes desconheciam a qual grupo pertenciam?

( ) Sim ( ) Não ( ) Não claro Não mencionado Os responsáveis pela suplementação desconheciam a quais grupos cada participante pertencia?

( ) Sim ( ) Não $\quad(\quad)$ Não claro $\quad(\quad)$ Não mencionado

\section{Viés de seguimento}

As perdas de seguimento foram semelhantes nos grupos?

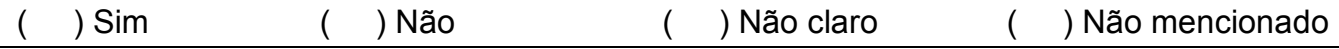

\section{Viés de detecção}

Os responsáveis pelas análises dos dados desconheciam quais eram os grupos intervenção e controle?

( ) Sim ( ) Não ( ) Não claro Não mencionado

Foi realizada análise por intenção de tratamento?

$\begin{array}{llll}() \operatorname{Sim} & (\text { Não } & (\quad) \text { Não claro } \quad(\quad) \text { Não mencionado }\end{array}$

\section{Classificação do Estudo - Risco de Vieses}

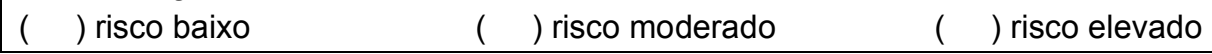

Avaliação da Adequacão do Sigilo de Alocação (traducão livre)

\begin{tabular}{|l|l|}
\hline ( $\quad$ ) A - Adequado & $\begin{array}{l}\text { Aleatorização centralizada; administração seqüencial de } \\
\text { pacotes/envelopes pré-codificados ou numerados; dados } \\
\text { gerados por um programa de computador; pessoa responsável } \\
\text { pelo sorteio não envolvida diretamente na alocação do paciente. }\end{array}$ \\
\hline ( $\quad$ ) B - Não claro & $\begin{array}{l}\text { A abordagem de alocação utilizada não é mencionada ou há } \\
\text { suspeita de falha. }\end{array}$ \\
\hline ( $\quad$ ) C - Inadequado & $\begin{array}{l}\text { Alternância; utilização de números de prontuários, datas de } \\
\text { nascimento, dias da semana ou qualquer outro processo não } \\
\text { sigiloso (lista aberta de números aleatórios). }\end{array}$ \\
\hline ( $\quad$ ) D - Não utilizado & Não houve sigilo de alocação dos participantes nos grupos. \\
\hline
\end{tabular}


ANEXO 2

\section{CHECKLIST FOR MEASURING STUDY QUALITY Downs \& Black (1998)}

\section{Reporting}

1. Is the hypothesis/aim/objective of the study clearly described?

\begin{tabular}{|l|l|l|l|}
\hline 1 & Yes & 0 & No \\
\hline
\end{tabular}

2. Are the main outcomes to be measured clearly described in the Introduction or Methods section?

If the main outcomes are first mentioned in the Results section, the question should be answered No.

\begin{tabular}{|l|l|l|l|}
\hline 1 & Yes & 0 & No \\
\hline
\end{tabular}

3. Are the characteristics of the patients included in the study clearly described?

In cohort studies and trials, inclusion and/or exclusion criteria should be given. In case-control studies, a casedefinition and the source for controls should be given.

\begin{tabular}{|l|l|l|l|}
\hline 1 & Yes & 0 & No \\
\hline
\end{tabular}

4. Are the interventions of interest clearly described?

Treatments and placebo (where relevant) that are to be compared should be clearly described.

\begin{tabular}{|l|l|l|l|}
\hline 1 & Yes & 0 & No \\
\hline
\end{tabular}

5. Are the distributions of principal confounders in each group of subjects to be compared clearly described?

A list of principal confounders is provided.

\begin{tabular}{|c|l|c|l|l|l|}
\hline 2 & Yes & 1 & Partially & 0 & No \\
\hline
\end{tabular}

6. Are the main findings of the study clearly described?

Simple outcome data (including denominators and numerators) should be reported for all major findings so that the reader can check the major analyses and conclusions (This question does not cover statistical testes which are considered below).

\begin{tabular}{|l|l|l|l|}
\hline 1 & Yes & 0 & No \\
\hline
\end{tabular}

7. Does the study provide estimates of the random variability in the data for the main outcomes?

In non-normally distributed data the inter-quartile range of results should be reported. In normally distributed data the standard error, standard deviation or confidence intervals should be reported. If the distribution of the data is not described, it must be assumed that the estimates used were appropriate and the question should be answered Yes.

\begin{tabular}{|l|l|l|l|}
\hline 1 & Yes & 0 & No \\
\hline
\end{tabular}

8. Have all important adverse events that may be a consequence of the intervention been reported?

This should be answered Yes if the study demonstrates that there was a comprehensive attempt to measure adverse events (a list of possible adverse events if provided).

\begin{tabular}{|l|l|l|l|}
\hline 1 & Yes & 0 & No \\
\hline
\end{tabular}


9. Have the characteristics of patients lost to follow-up been described?

This should be answered Yes where there were no losses of follow-up or where losses to follow-up were so small that the findings would be unaffected by their inclusion. This should be answered No where a study does not report the number of patients lost to follow-up.

\begin{tabular}{|l|l|l|l|}
\hline 1 & Yes & 0 & No \\
\hline
\end{tabular}

10. Have actual probability values been reported (e.g. 0.035 rather than $<0.05$ ) for the main outcomes except where the probability value is less than 0.001 ?

\begin{tabular}{|l|l|l|l|}
\hline 1 & Yes & 0 & No \\
\hline
\end{tabular}

\section{External Validity}

All the following criteria attempt to address the representativeness of the findings of the study and whether they may be generalised to the population from which study subjects were derived.

11. Were the subjects asked to participate in the study representative of the entire population from which they were recruited?

The study must identify the source population for patients and described how the patients were selected. Patients would be representative if they comprised the entire source population, an unselected sample of consecutive patients, or a random sample. Random sampling is only feasible where a list of all members of the relevant population exists. Where a study does not report the proportion of the source population from which the patients are derived, the question should be answered as Unable to determine.

\begin{tabular}{|l|l|l|l|l|l|}
\hline 1 & Yes & 0 & No & 0 & Unable to determine \\
\hline
\end{tabular}

12. Were those subjects who were prepared to participate representative of the entire population from which they were recruited?

The proportion of those asked who agreed should be stated. Validation that the sample was representative would include demonstrating that the distribution of the main confounding factors was the same in the study sample and the source population.

\begin{tabular}{|c|l|l|l|l|l|}
\hline 1 & Yes & 0 & No & 0 & Unable to determine \\
\hline
\end{tabular}

13. Were the staff, places, and facilities where the patients were treated, representative of the treatment the majority of patients receive?

For the question to be answered Yes the study should demonstrate that the intervention was representative of that in use in the source population. The question should be answered No if, for example, the intervention was undertaken in a specialist centre unrepresentative of the hospitals most of the source population would attend.

\begin{tabular}{|l|l|l|l|c|l|}
1 & Yes & 0 & No & 0 & Unable to determine \\
\hline
\end{tabular}

\section{Internal Validity - Bias}

14. Was an attempt made to blind study subjects to the intervention they have received? For studies where the patients would have no way of knowing which intervention they received, this should be answered Yes.

\begin{tabular}{|l|l|l|l|l|l|}
\hline 1 & Yes & 0 & No & 0 & Unable to determine \\
\hline
\end{tabular}

15. Was an attempt made to blind those measuring the main outcomes of the intervention?

\begin{tabular}{|l|l|l|l|l|l|}
\hline 1 & Yes & 0 & No & 0 & Unable to determine \\
\hline
\end{tabular}


16. If any of the results of the study were based on "data dredging", was this made clear? Any analyses that had not been planned at the outset of the study should be clearly indicated. If no retrospective unplanned subgroup analyses were reported, then answer Yes.

\begin{tabular}{|l|l|l|l|l|l|}
1 & Yes & 0 & No & 0 & Unable to determine \\
\hline
\end{tabular}

17. In trials and cohort studies, do the analyses adjust for different lenghts of follow-up of patients, or in case-control studies, is the time period between the intervention and outcome the same for cases and controls?

Where follow-up was the same for all study patients the answer should be Yes. If different lengths of follow-up were adjusted by, for example, survival analysis, the answer should be Yes. Studies where differences in follow-up are ignored should be answered No.

\begin{tabular}{|l|l|l|l|l|l|}
\hline 1 & Yes & 0 & No & 0 & Unable to determine \\
\hline
\end{tabular}

18. Were the statistical tests used to assess the main outcomes appropriate?

The statistical techniques used must be appropriate to the data. For example non parametric methods should be used for small sample sizes. Where little statistical analysis has been undertaken but there is no evidence of bias, the question should be answered Yes. If the distribution of the data (normal or not) is not described it must be assumed that the estimates used were appropriate and the question should be answered Yes.

\begin{tabular}{|l|l|l|l|l|l|}
\hline 1 & Yes & 0 & No & 0 & Unable to determine \\
\hline
\end{tabular}

19. Was compliance to the intervention reliable?

Where there was no compliance with the allocated treatment or where there was a contamination of one group, the question should be answered No. For studies where the effect of any misclassification was likely to bias any association to the null, the question should be answered Yes.

\begin{tabular}{|c|l|c|l|c|l|}
\hline 1 & Yes & 0 & No & 0 & Unable to determine \\
\hline
\end{tabular}

20. Were the main outcome measures used accurate (valid and reliable)?

For studies where the outcome measures are clearly described, the question should be answered Yes. For studies which refer to other work or that demonstrates the outcome measures are accurate, the question should be answered Yes.

\begin{tabular}{|l|l|l|l|l|l|}
\hline 1 & Yes & 0 & No & 0 & Unable to determine \\
\hline
\end{tabular}

\section{Internal Validity - confounding (selection bias)}

21. Were the patients in different intervention groups (trials and cohort studies) or were the cases and controls (case-control studies) recruited from the same population?

For example, patients for all comparison groups should be selected from the same hospital. The question should be answered unable to determine for cohort and case-control studies where there is no information concerning the source of patients included in the study.

\begin{tabular}{|l|l|l|l|l|l|}
1 & Yes & 0 & No & 0 & Unable to determine \\
\hline
\end{tabular}

22. Were study subjects in different intervention groups (trials and cohort studies) or were the cases and controls (case-control studies) recruited over the same period of time?

For a study which does not specify the time period over which patients were recruited, the question should be answered as Unable to determine.

\begin{tabular}{|l|l|l|l|l|l|}
\hline 1 & Yes & 0 & No & 0 & Unable to determine \\
\hline
\end{tabular}

23. Were study subjects randomised to intervention groups?

Studies which state that subjects were randomised should be answered Yes except where method of randomisation would not ensure random allocation. For example alternate allocation would score no points because it is predictable.

\begin{tabular}{|c|l|l|l|l|l|}
\hline 1 & Yes & 0 & No & 0 & Unable to determine \\
\hline
\end{tabular}


24. Was the randomised intervention assignment concealed from both patients and health care staff until recruitment was complete and irrevocable?

All non-randomised studies should be answered No. If assignment was concealed from patients but not from staff, it should be answered No.

\begin{tabular}{|l|l|l|l|l|l|}
\hline 1 & Yes & 0 & No & 0 & Unable to determine \\
\hline
\end{tabular}

25. Was there adequate adjustment for confounding in the analyses from which the main findings were drawn?

This question should be answered no for trials if the main conclusions of the study were based on analyses of treatment rather than intention to treat; the distribution of known confounders in the different treatment groups was not described; or the distribution of known confounders differed between the treatment groups but was not taken into account in the analyses. In non-randomised studies if the effect of the main confounders was not investigated or confounding was demonstrated but no adjustment was made in the final analyses the question should be answered as No.

\begin{tabular}{|l|l|l|l|l|l|}
\hline 1 & Yes & 0 & No & 0 & Unable to determine \\
\hline
\end{tabular}

26. Were losses of patients to follow-up taken into account?

If the numbers of patients lost to follow-up are not reported, the question should be answered as Unable to determine. If the proportion lost to follow-up was too small to affect the main findings, the question should be answered Yes.

\begin{tabular}{|l|l|l|l|l|l|}
\hline 1 & Yes & 0 & No & 0 & Unable to determine \\
\hline
\end{tabular}

\section{Power}

27. Did the study have sufficient Power to detect a clinically important effect where the probability value for a difference being due to chance is less than $5 \%$ ?

Sample sizes have been calculated to detect a difference of $\mathrm{x} \%$ and $\mathrm{y} \%$.

\begin{tabular}{|c|c|}
\hline & $\begin{array}{c}\text { Size of the smallest } \\
\text { intervention group }\end{array}$ \\
\hline 0 & $<\mathrm{n}_{1}$ \\
\hline 1 & $\mathrm{n}_{1}-\mathrm{n}_{2}$ \\
\hline 2 & $\mathrm{n}_{3}-\mathrm{n}_{4}$ \\
\hline 3 & $\mathrm{n}_{5}-\mathrm{n}_{6}$ \\
\hline 4 & $\mathrm{n}_{7}-\mathrm{n}_{8}$ \\
\hline 5 & $\mathrm{n}_{8}+$ \\
\hline
\end{tabular}




\section{APÊNDICE 2}

\section{DOCUMENTAÇÃO DAS BUSCAS NAS BASES DE DADOS BIBLIOGRÁFICAS}

Base de dados bibliográficos: Pubmed/Medline

Data da pesquisa bibliográfica: 14/08/2009

Período coberto pela busca: 1947 a agosto de 2009.

Limites:

Humans, Female, Clinical Trial, Randomized Controlled Trial, Comparative Study, Controlled Clinical Trial, Evaluation Studies, English, Spanish, Portuguese

\begin{tabular}{|c|c|c|}
\hline Busca & Estratégia & Resultado \\
\hline$\# 4$ & $\begin{array}{l}\text { \#1 AND \#2 AND \#3 Limits: Humans, Female, Clinical Trial, } \\
\text { Randomized Controlled Trial, Comparative Study, Controlled } \\
\text { Clinical Trial, Evaluation Studies, English, Spanish, Portuguese }\end{array}$ & 11 \\
\hline \#3 & $\begin{array}{l}\text { pregnancy[TIAB] OR pregnant women[TIAB] OR pregnant } \\
\text { woman[TIAB] OR gestation[TIAB] OR gestation period[TIAB] OR } \\
\text { gestational period[TIAB]) Limits: Humans, Female, Clinical Trial, } \\
\text { Randomized Controlled Trial, Comparative Study, Controlled } \\
\text { Clinical Trial, Evaluation Studies, English, Spanish, Portuguese }\end{array}$ & 25572 \\
\hline \#2 & $\begin{array}{l}\text { supplement }^{*}[\mathrm{TIAB}] \\
\text { supplement* OR dietary supplement* }{ }^{*}[\mathrm{TIAB}] \text { OR diet } \\
\text { Humans, Female, Clinical Trial, Randomized Controlled Trial, } \\
\text { Comparative Study, Controlled Clinical Trial, Evaluation Studies, } \\
\text { English, Spanish, Portuguese }\end{array}$ & 15895 \\
\hline \#1 & $\begin{array}{l}\text { selenium[TIAB] OR selenium compound*[TIAB] OR selenious } \\
\text { acid[TIAB] OR sodium selenide[TIAB] OR sodium selenite[TIAB] } \\
\text { OR selenite[TIAB] OR sodium selenate[TIAB] OR selenate[TIAB] } \\
\text { OR calcium selenite[TIAB] OR selenomethionine[TIAB] OR } \\
\text { selenium yeast[TIAB] OR selenium-yeast[TIAB] OR yeast- } \\
\text { selenium[TIAB] OR yeast-Se[TIAB] OR yeast selenium[TIAB]) } \\
\text { Limits: Humans, Female, Clinical Trial, Randomized Controlled } \\
\text { Trial, Comparative Study, Controlled Clinical Trial, Evaluation } \\
\text { Studies, English, Spanish, Portuguese }\end{array}$ & 710 \\
\hline
\end{tabular}

Total de estudos encontrados: 11 
Base de dados bibliográficos: EMBASE

Data da pesquisa bibliográfica: 17/08/2009

Período coberto pela busca: 1947 a agosto de 2009.

Limites:

Search publications from: all years

Advanced search: map to preferred terminology; include sub-terms/derivatives

Quick limits: humans

Advanced limits: evidence based medicine (controlled clinical trial, randomized controlled trial), publication types (article, conference abstract, conference paper), article languages (Portuguese, English, Spanish), gender: female

\begin{tabular}{|c|c|c|}
\hline Busca & Estratégia & Resultado \\
\hline$\# 4$ & \#1 AND \#2 AND \#3 & 7 \\
\hline \#3 & $\begin{array}{l}\text { 'pregnancy'/exp OR 'gestation period'/exp OR 'pregnant } \\
\text { woman'/exp AND ([controlled clinical trial]/lim OR [randomized } \\
\text { controlled trial]/lim) AND ([article]/lim OR [conference abstract]/lim } \\
\text { OR [conference paper]/lim) AND ([english]/lim OR [portuguese]/lim } \\
\text { OR [spanish]/lim) AND [female]/lim AND [humans]/lim }\end{array}$ & 5016 \\
\hline \#2 & $\begin{array}{l}\text { 'diet supplementation'/exp OR 'dietary intake'/exp OR 'yeast'/exp } \\
\text { AND ([controlled clinical trial]/lim OR [randomized controlled } \\
\text { trial]/lim) AND ([article]/lim OR [conference abstract]/lim OR } \\
\text { [conference paper]/lim) AND ([english]/lim OR [portuguese]/lim OR } \\
\text { [spanish]/lim) AND [female]/lim AND [humans]/lim }\end{array}$ & 8814 \\
\hline \#1 & $\begin{array}{l}\text { 'selenium'/exp OR 'selenium derivative'/exp OR 'selenious } \\
\text { acid'/exp OR 'sodium selenite'/exp OR 'selenite'/exp OR } \\
\text { 'selenate'/exp OR 'selenium sulfate'/exp OR 'selenium sulfide'/exp } \\
\text { AND ([controlled clinical trial]/lim OR [randomized controlled } \\
\text { trial]//im) AND ([article]/lim OR [conference abstract]/lim OR } \\
\text { [conference paper]/lim) AND ([english]/lim OR [portuguese]/lim OR } \\
\text { [spanish]/lim) AND [female]/lim AND [humans]/lim }\end{array}$ & 330 \\
\hline
\end{tabular}

Total de estudos encontrados: 7 
Base de dados bibliográficos: SCOPUS

Data da pesquisa bibliográfica: 17/08/2009

Período coberto pela busca: 1823 a agosto de 2009 .

\begin{tabular}{|c|c|c|}
\hline Busca & Estratégia & Resultado \\
\hline$\# 4$ & \#1 AND \#2 AND \#3 & 0 \\
\hline \#3 & $\begin{array}{l}\text { Title-abs-key(pregnancy OR "pregnant women" OR gestation OR } \\
\text { "gestation period" OR "gestational period") }\end{array}$ & 40416 \\
\hline$\# 2$ & $\begin{array}{l}\text { Title-abs-key(supplement* OR supplementation OR "dietary } \\
\text { supplement*” OR “dietary supplementation" OR "diet } \\
\text { supplement*” OR “diet supplementation" OR "dietary selenium” } \\
\text { OR “maternal supplement" OR "maternal supplementation") }\end{array}$ & 8830 \\
\hline \#1 & $\begin{array}{l}\text { Title-abs-key(selenium OR "selenium compound"” OR "selenious } \\
\text { acid" OR "sodium selenide" OR "sodium selenite" OR selenite OR } \\
\text { "sodium selenate" OR selenate OR “calcium selenite" OR } \\
\text { "disodium selenate" OR selenomethionine OR "selenium yeast" } \\
\text { OR "selenium-yeast" OR "yeast-selenium" OR "yeast-Se" OR } \\
\text { "yeast selenium"OR "selenium-enriched food") }\end{array}$ & 0 \\
\hline
\end{tabular}

Total de estudos encontrados: 0 
Base de dados bibliográficos: Pro Quest Dissertations and Theses

Data da pesquisa bibliográfica: 17/08/2009

Período coberto pela busca: 1716 a agosto 2009

Limites:

Databases: Interdisciplinary - Dissertations \& Theses

Campos: abstract

\begin{tabular}{|c|l|c|}
\hline Busca & Estratégia & Resultado \\
\hline$\# 5$ & $\# 1$ AND \#2 AND \#3 AND NOT \#4 & 0 \\
\hline$\# 4$ & $\begin{array}{l}\text { murine OR porcine OR bovine OR cattle OR ewe OR deers OR } \\
\text { rats OR sow OR rabbits OR cows }\end{array}$ & 53682 \\
\hline$\# 3$ & $\begin{array}{l}\text { pregnancy OR gestation OR gestational period OR pregnant } \\
\text { women OR gestation period }\end{array}$ & 10993 \\
\hline S2 & $\begin{array}{l}\text { supplement OR supplements OR supplementation OR dietary } \\
\text { supplement OR dietary supplements OR dietary supplementation } \\
\text { OR diet supplement OR diet supplements OR diet } \\
\text { supplementation OR maternal supplement OR maternal } \\
\text { supplements OR maternal supplementation }\end{array}$ & 1601 \\
\hline \multirow{2}{*}{$\begin{array}{l}\text { selenium OR selenomethionine OR selenium compounds OR } \\
\text { selenium compound OR selenite OR selenate OR selenious acid } \\
\text { OR sodium selenide OR selenium yeast OR selenium-yeast OR } \\
\text { yeast-selenium OR yeast-Se OR yeast selenium }\end{array}$} & \\
\hline
\end{tabular}

Total de estudos encontrados: 
Base de dados bibliográficos: Web of Science with Conference Proceedings

Data da pesquisa bibliográfica: 17/08/2009

Período coberto pela busca: 1900 a agosto de 2009

Limites:

All years

Citation databases: Science citation index expanded, Conference proceedings citation indexscience

Restrict results by any or all of the options below:

Languages: English, Portuguese and Spanish

Document types: Article, Meeting Abstract, Meeting Summary, Meeting-Abstract, Proceedings Paper

\begin{tabular}{|c|c|c|}
\hline Busca & Estratégia & Resultado \\
\hline \#6 & \#4 NOT \#5 & 44 \\
\hline \#5 & 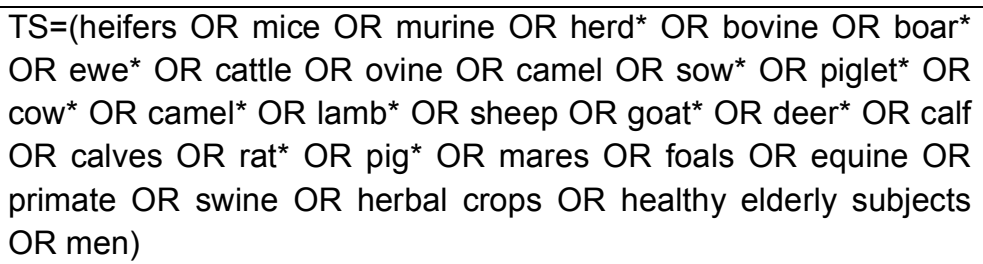 & $>100.000$ \\
\hline \#4 & \#1 AND \#2 AND \#3 & 224 \\
\hline \#3 & $\begin{array}{l}\text { TS=(pregnancy OR "pregnant women" OR "pregnant woman" OR } \\
\text { gestation OR "gestation period" OR "gestational period") }\end{array}$ & $>100.000$ \\
\hline \#2 & $\begin{array}{l}\text { TS=(supplement* OR supplementation OR "dietary supplement*" } \\
\text { OR "dietary supplementation" OR "diet supplement*" OR "diet } \\
\text { supplementation" OR "maternal supplement } \\
\text { supplementation") }\end{array}$ & $>100.000$ \\
\hline \#1 & $\begin{array}{l}\text { TS=(selenium OR "selenium compound" OR "selenious acid" OR } \\
\text { "sodium selenide" OR "sodium selenite" OR selenite OR "sodium } \\
\text { selenate" OR selenate OR "calcium selenite" OR "disodium } \\
\text { selenate" OR selenomethionine OR "selenium yeast" OR "yeast } \\
\text { selenium" OR "selenium-yeast" OR "yeast-selenium" OR "yeast- } \\
\text { Se" OR "selenium-enriched food") }\end{array}$ & 37119 \\
\hline
\end{tabular}

Total de estudos encontrados: 44 
Base de dados bibliográficos: Science Direct

Data da pesquisa bibliográfica: 17/08/2009

Período coberto pela busca: 1823 a agosto de 2009

Limites:

Include: journals

Sources: all sources

Subject: Agricultural and biological sciences; biochemistry, genetics and molecular biology; decision sciences; immunology and microbiology; medicine and dentistry; nursing and health professions; pharmacology, toxicology and pharmaceutical science.

\begin{tabular}{|c|c|c|}
\hline Busca & Estratégia & Resultado \\
\hline$\# 4$ & \#1 AND \#2 AND \#3 & 5 \\
\hline \#3 & $\begin{array}{l}\text { (pregnancy OR "pregnant women" OR gestation OR "gestation } \\
\text { period" OR "gestational period") }\end{array}$ & 122666 \\
\hline \#2 & $\begin{array}{l}\text { (supplement* OR supplementation OR "dietary supplement*" OR } \\
\text { "dietary supplementation" OR "diet supplement" OR "diet } \\
\text { supplementation" OR "dietary selenium" OR "maternal } \\
\text { supplement" OR "maternal supplementation") }\end{array}$ & 17594 \\
\hline \#1 & $\begin{array}{l}\text { selenium OR "selenium compound" OR "selenious acid" OR } \\
\text { "sodium selenide" OR “sodium selenite" OR selenite OR "sodium } \\
\text { selenate" OR selenate OR “calcium selenite" OR “disodium } \\
\text { selenate" OR selenomethionine OR "selenium yeast" OR } \\
\text { "selenium-yeast" OR “yeast-selenium" OR "yeast-Se" OR "yeast } \\
\text { selenium"OR "selenium-enriched food" }\end{array}$ & 19 \\
\hline
\end{tabular}

Total de estudos encontrados: 5 
Base de dados bibliográficos: Food Science and Technology Abstracts

Data da pesquisa bibliográfica: 17/08/2009

Período coberto pela busca: 1969 a agosto de 2009

Limites:

Search in Food Science Central

Campo: Free text

\begin{tabular}{|c|c|c|}
\hline Busca & Estratégia & Resultado \\
\hline \#3 & \#1 AND \# 2 & 0 \\
\hline \#2 & $\begin{array}{l}\text { ("pregnancy" OR "pregnant women" OR "gestation" OR "gestation } \\
\text { period" OR "gestational period") }\end{array}$ & \\
\hline \#1 & $\begin{array}{l}\text { ("selenium" OR "selenium compound" OR "selenium compounds" } \\
\text { OR "selenious acid" OR "sodium selenide" OR "sodium selenite" } \\
\text { OR "selenite" OR "sodium selenate" OR "selenate" OR "calcium } \\
\text { selenite" OR "disodium selenate" OR "selenomethionine" OR } \\
\text { "selenium yeast" OR "selenium-yeast" OR "yeast-selenium" OR } \\
\text { "yeast-Se" OR "yeast selenium" OR "selenium-enriched food" }\end{array}$ & \\
\hline
\end{tabular}

Total de estudos encontrados: 0 
Base de dados bibliográficos: LILACS

Data da pesquisa bibliográfica: 22/08/2009

Período coberto pela busca: 1980 a agosto de 2009

Campo: descritor de assunto

\begin{tabular}{|c|l|c|}
\hline Busca & Estratégia & Resultado \\
\hline$\# 4$ & $\# 1$ AND \#2 AND \#3 & 0 \\
\hline$\# 3$ & (gestação OR gravidez OR gestantes) & 16622 \\
\hline$\# 2$ & $\begin{array}{l}\text { (suplementação alimentar OR suplementos dietéticos OR } \\
\text { suplement\$) }\end{array}$ & 757 \\
\hline$\# 1$ & $\begin{array}{l}\text { selenio OR compostos de selênio OR selenometionina OR } \\
\text { selenito de sodio }\end{array}$ & 83 \\
\hline
\end{tabular}

Total de estudos encontrados: 0 
Base de dados bibliográficos: CINAHL with Full Text

Data da pesquisa bibliográfica: 17/08/2009

Período coberto pela busca: 1981 a agosto de 2009

Campos: "abstract"

\begin{tabular}{|c|l|c|}
\hline Busca & Estratégia & Resultado \\
\hline$\# 4$ & $\# 1$ AND \#2 AND \#3 & 10 \\
\hline$\# 3$ & $\begin{array}{l}\text { pregnancy OR "pregnant women" OR gestation OR "gestation } \\
\text { period" OR "gestational period" }\end{array}$ & 12998 \\
\hline$\# 2$ & $\begin{array}{l}\text { supplement* OR supplementation OR "dietary supplement" OR } \\
\text { "dietary supplementation" OR "diet supplement”" OR "diet } \\
\text { supplementation" }\end{array}$ & $\begin{array}{l}\text { selenium OR selenium compound" OR "selenious acid" OR } \\
\text { "sodium selenide" OR "sodium selenite" OR selenite OR "sodium } \\
\text { selenate" OR selenate OR "calcium selenite" OR "disodium } \\
\text { selenate" OR selenomethionine OR "selenium yeast" OR "yeast } \\
\text { selenium" OR "selenium-yeast" OR "yeast-selenium" OR "yeast- } \\
\text { Se" OR "selenium-enriched food" }\end{array}$ \\
\hline
\end{tabular}

Total de estudos encontrados: 10 
Base de dados bibliográficos: Current Contents Connect

Data da pesquisa bibliográfica: 17/08/2009

Período coberto pela busca: 1998 a agosto de 2009

Limites:

All years

Current contents editions: Agriculture, Biology and Environmental Sciences; Life Sciences

Languages: English, Portuguese and Spanish

Document types: article and meeting abstract.

\begin{tabular}{|c|c|c|}
\hline Busca & Estratégia & Resultado \\
\hline$\# 6$ & \#4 NOT \#5 & 31 \\
\hline \#5 & 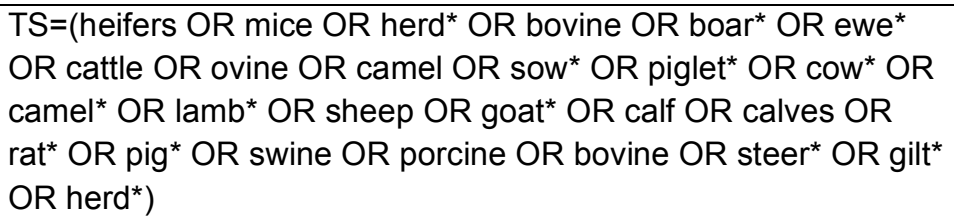 & $>100000$ \\
\hline$\# 4$ & \#1 AND \#2 AND \#3 & 142 \\
\hline \#3 & $\begin{array}{l}\text { TS=(pregnancy OR "pregnant women" OR "pregnant woman" } \\
\text { OR gestation OR "gestation period" OR "gestational period") }\end{array}$ & 64150 \\
\hline$\# 2$ & $\begin{array}{l}\text { TS=(supplement* OR supplementation OR "dietary supplement*" } \\
\text { OR "dietary supplementation" OR "diet supplement*" OR "diet } \\
\text { supplementation" OR "maternal supplement }{ }^{* " ~ O R ~ " m a t e r n a l ~} \\
\text { supplementation") }\end{array}$ & 75604 \\
\hline \#1 & $\begin{array}{l}\text { TS=(selenium OR "selenium compound*" OR "selenious acid" } \\
\text { OR "sodium selenide" OR "sodium selenite" OR selenite OR } \\
\text { "sodium selenate" OR selenate OR "calcium selenite" OR } \\
\text { "disodium selenate" OR selenomethionine OR "selenium yeast" } \\
\text { OR "yeast selenium" OR "selenium-yeast" OR "yeast-selenium" } \\
\text { OR "yeast-Se" OR "selenium-enriched food") }\end{array}$ & 9413 \\
\hline
\end{tabular}

Total de estudos encontrados: 31 
Base de dados bibliográficos: EBM Reviews (All EBM reviews: Cochrane Database of Systematic Reviews, ACP Journal Club, Database of Abstracts of Reviews of Effect, Cochrane Central Register of Controlled Trials, Cochrane Methodology Register, Health Technology Assessment, and NHS Economic Evaluation Database

Data da pesquisa bibliográfica: 17/08/2009

Período coberto pela busca: 1998 a agosto de 2009

Multifield Search - campos: abstract

\begin{tabular}{|c|l|c|}
\hline Busca & Estratégia & Resultado \\
\hline$\# 4$ & $\# 1$ AND \#2 AND \#3 & 15 \\
\hline$\# 3$ & $\begin{array}{l}\text { pregnancy OR gestation OR gestational period OR } \\
\text { pregnant women OR gestation period }\end{array}$ & 11331 \\
\hline$\# 2$ & $\begin{array}{l}\text { supplement OR supplements OR supplementation OR dietary } \\
\text { supplement OR dietary supplements OR dietary } \\
\text { supplementation OR diet supplement OR diet supplements OR } \\
\text { diet supplementation OR maternal supplement OR maternal } \\
\text { supplements OR maternal supplementation }\end{array}$ & 563 \\
\hline Selenium OR selenomethionine OR selenium compounds \\
$\begin{array}{l}\text { OR selenium compound OR selenite OR selenate OR } \\
\text { selenious acid OR sodium selenite OR selenium yeast OR } \\
\text { selenium-yeast OR yeast-selenium OR yeast-Se OR yeast } \\
\text { selenium }\end{array}$ & \\
\hline
\end{tabular}

Total de estudos encontrados: 15 


\section{APÊNDICE 3}

\section{REFERÊNCIAS DOS ESTUDOS LOCALIZADOS (APÓS A EXCLUSÃO DE DUPLICATAS)}

Review: antioxidant supplements do not reduce all-cause mortality in primary or secondary prevention. Annals of Internal Medicine, v. 149, n. 6, p. JC3-JC9, set. 2008.

High vitamin A intake in early pregnancy was associated with birth defects. Evidence Based Medicine, v. 1, p. 124, mai-jun. 1996.

NATIONAL INSTITUTES OF HEALTH. National Institutes of Health state-of-science conference statement: multivitamin/mineral supplements and chronic disease prevention. Annals of Internal Medicine, v. 145, n. 5, p. 364-371, mai. 2006.

AASETH, J. Y. et al. Prophylactic iron supplementation in pregnant women in Norway. Journal of Trace Elements in Medicine and Biology, v. 15, n. 2-3, p. 167-174, 2001.

AHN, E. N. et al. A randomized cross over trial of tolerability and compliance of a micronutrient supplement with low iron separated from calcium vs high iron combined with calcium in pregnant women. BMC Pregnancy and Childbrith, v. 6, n. 10, p. 1-6, abr. 2006.

AJAYI, G. O. Selenium concentration in first trimester abortion in Nigerian women. Trace Elements and Electrolytes, v. 21, n. 1, p. 1-3, 2004.

AL-KUNANI, A. S. et al. The selenium status of women with a history of recurrent miscarriage. British Journal of Obstetrics and Gynaecology, v. 108, n. 10, p. 1094-1097, out. 2001.

ALLEN, L.H. Multiple micronutrients in pregnancy and lactation: an overview. The American Journal of Clinical Nutrition, v. 81, s. 1, p.1206S-1212S, mai. 2005.

AL-SALEH, I. Selenium status in Saudi Arabia. Journal of Trace Elements in Medicine and Biology, v. 14, n. 3, p. 154-160, out. 2000.

ARNAUD J. A. et al. Effect of iron supplementation during pregnancy on trace element $(\mathrm{Cu}$, $\mathrm{Se}, \mathrm{Zn}$ ) concentrations in serum and breast-milk from Nigerian women. Annals of Nutrition and Metabolism, v. 37, n. 5, p. 262-271, 1993.

BARRINGTON, J. W. et al. Selenium deficiency and miscarriage: a possible link? British Journal of Obstetrics and Gynaecology, v. 103, n. 2, p. 130-132, fev. 1996.

BATES, C.J.; PRENTICE, A. Breast milk as a source of vitamins, essential minerals and trace elements. Pharmacology and Therapeutics, v. 62, n. 1-2, p. 193-220, abr.-mai. 1994.

BHAN, M. K.; SOMMERFELT, H.; STRAND, T. Micronutrient deficiency in children. British Journal of Nutrition, v. 85, s. 2, p. S199-S203, mai. 2001. 
BHASKARAM, P. Micronutrient malnutrition, infection and immunity: an overview. Nutrition Reviews, v. 60, n.5, p. S40-S45, mai. 2002.

BLACK, R. E. Micronutrients in pregnancy. British Journal of Nutrition, v. 85, s. 2, p. S193-S197, mai. 2001.

$\mathrm{BRO}$, S. et al. Serum selenium concentration in maternal and umbilical cord blood. Relation to course and outcome of pregnancy. Journal of Trace Elements and Electrolytes in Health and Disease, v. 2, n. 3, p. 165-169, set. 1988.

CENGIZ, B. et al. Serum zinc, selenium, copper, and lead levels in women with secondtrimester induced abortion resulting from neural tube defects. Biological Trace Element Research, v. 97, n. 3, p. 225-235, mar. 2004.

CHEŁCHOWSKA, M et al. The effect of vitamin-mineral supplementation on the level of MDA and activity of glutathione peroxidase and superoxide dismutase in blood of matched maternal-cord pairs. Przegl Lek, v. 61, n. 7, p. 760-763, 2004.

CHEN, Y. et al. Association between arsenic exposure from drinking water and plasma levels of soluble cell adhesion molecules. Environmental Health Perspectives, v. 115, n. 10, p. 1415-1420, out. 2007.

DANIELS, L. A. et al. Glutathione peroxidase is not a functional marker of selenium status in the neonatal period. Journal of Pediatric Gastroenterology and Nutrition, v. 26, n. 3, p. 263-268, mar. 1998.

DARLOW, B. A. et al. The relationship of selenium status to respiratory outcome in the very low birth weight infants. Pediatrics, v. 96, n.2, p. 314-319, ago. 1995.

DARLOW, B. A. et al. The effect of selenium supplementation on outcome in very low birth weight infants: a randomized controlled trial. The Journal of Pediatrics, v. 136, n. 4, p. 473480, abr. 2000.

DAWSON, E. B.; ALBERS, J. H.; McGANITY, W.J. The apparent effect of iron supplementation on serum selenium levels in teenage pregnancy. Biological Trace Element Research, v. 77, n. 3, p. 209-217, dez. 2000.

DAWSON, E. B.; EVANS, D. R.; NOSOVITCH, J. Third-trimester amniotic fluid metal levels associated with preeclampsia. Archives of Environmental Health, v.54, n.6, p. 412-415, nov./dez. 1999.

DERBYSHIRE, E. et al. Habitual micronutrient intake during and after pregnancy in Caucasian Londoners. Maternal and Child Nutrition, v. 5, n. 1, p. 1-9, jan. 2009.

DEVEREUX, G. et al. Early childhood wheezing symptoms in relation to plasma selenium in pregnant mothers and neonates. Clinical and Experimental Allergy, v. 37, n. 7, p. 10001008, jul. 2007.

DISON, P. J. et al. Influence of maternal factors on cord and neonatal plasma micronutrient levels. American Journal of Perinatology, v. 10, n. 1, p. 30-35, jan. 1993. 
DODGE, M. L. et al. Selenium supplementation increases the polyunsaturated fatty acid content of human breast milk. The Journal of Trace Elements in Experimental Medicine, v. 12, n. 1, p. 37-44, jan. 1999.

ELIAS, S. lodine and selenium - 'trace' minerals in New Zealand. New Zealand College of Midwives Journal, v. 36, p. 25-27, abr. 2007.

FAWZI, W. Micronutrients and human immunodeficiency virus type 1 disease progression among adults and children. Clinical Infectious Diseases, v. 37, n. 2, p. S112-S116, jul. 2003.

FAWZI, W. et al. Studies of vitamins and minerals and HIV transmission and disease progression. Journal of Nutrition, v. 135, n. 4, p. 938-944, abr. 2005.

FILTEAU, S. M. et al. lodine deficiency alone cannot account for goiter prevalence among pregnant-women in Modhupur, Bangladesh. European Journal of Clinical Nutrition, v. 48, n. 4, p. 293-302, abr. 1994.

HAN, L.; ZHOU, S. Selenium supplement in the prevention of pregnancy induced hypertension. Chinese Medical Journal, v. 107, n. 11, p. 870-871, nov. 1994.

HOCMAN, G. Chemoprevention of cancer: selenium. International Journal of Biochemistry, v. 20, n. 2, p. 123-132, 1988.

HUANG, H. B. et al. The efficacy and safety of multivitamin and mineral supplement use to prevent cancer and chronic disease in adults: a systematic review for a National Institutes of Health state-of-the-science conference. Annals of Internal Medicine, v. 145, n. 5, p. 372385, set. 2006.

HUNT, C. D.; FRIEL, J. K.; JOHNSON, L. A. K. Boron concentrations in milk from mothers of full-term and premature infants. American Journal of Clinical Nutrition, v. 80, n. 5, p. 1327-1333, nov. 2004.

KILINC, M. et al. Evaluation of serum selenium levels in Turkish women with gestational diabetes mellitus, glucose intolerants, and normal controls. Biological Trace Element Research, v. 123, n. 1-3, p. 35-40, fev. 2008.

KING, J. C. Effect of reproduction on the bioavailability of calcium, zinc and selenium. Journal of Nutrition, v. 131, s. 1, p. 1355S-1358S, abr. 2001.

KOPSELL, D. A. et al. Selenization of Basil and Cilantro through foliar applications of selenate-selenium and selenite-selenium. Hortscience, v. 44, n. 2, p. 438-442, abr. 2009.

KOSANOVIC, M.; JOKANOVIC, M. The association of exposure to cadmium through cigarette smoke with pregnancy-induced hypertension in a selenium deficient population. Environmental Toxicology and Pharmacology, v. 24, n. 1, p. 72-78, jul. 2007.

KUBIK, P. et al. Effect of vitamin-mineral supplementation on the status of some microelements in pregnant women. Przegl Lek, v. 61, n. 7, p. 764-768, 2004. 
KUPKA, R. et al. Selenium status, pregnancy outcomes, and mother-to-child transmission of HIV. Journal of Acquired Immune Deficiency Syndromes, v. 39, n. 2, p. 203-210, jun. 2005.

KUPKA, R. et al. Selenium status is associated with accelerated HIV disease progression among HIV-1-infected pregnant women in Tanzania. Journal of Nutrition, v. 134, n. 10, p. 2556-2560, out. 2004.

KUPKA, R. et al. Relationship between plasma selenium concentrations and lower genital tract levels of HIV-1 RNA and interleukin type 1 beta. European Journal of Clinical Nutrition, v. 61, n. 4, p. 542-547, abr. 2007.

KUPKA, R. et al. Effect of selenium supplements on hemoglobin concentration and morbidity among HIV-1-infected Tanzanian women. Clinical Infectious Diseases, v. 48, n. 10, p. 1475-1478, mai. 2009.

KUPKA, R. et al. Randomized, double-blind, place-controlled trial of selenium supplements among HIV-infected pregnant women in Tanzania: effects on maternal and child outcomes. The American Journal of Clinical Nutrition, v. 87, n. 6, p. 1802-1808, jun. 2008.

LASKOWSKA-KLITA, T.; CHELCHOWSKA, M. KUBIK, P. Zinc, copper, selenium and activities of superoxide dismutase (SOD) and glutathione peroxidase (GPx) in blood of pregnant women after vitamin-mineral supplementation. Febs Journal, v. 272, p. 426-427, 2005.

LOMBECK, I.; JOCHUM, F.; TERWOLBECK, K. Selenium status in infants and children with phenylketonuria and in maternal phenylketonuria. European Journal of Pediatrics, v. 155, s. 1, p. S140-S144, jul. 1996.

MAGGINI, S. et al. Selected vitamins and trace elements support immune function by strengthening epithelial barriers and cellular and humoral immune responses. British Journal of Nutrition, v. 98, s. 1, p. S29-S35, out. 2007.

MAKHOUL, I. R. et al. Selenium concentrations in maternal and umbilical cord blood at 2442 weeks of gestation: basis for optimization of selenium supplementation to premature infants. Clinical Nutrition, v. 23, n. 3, p. 373-381, jun. 2004.

MASK, G.; LANE, H. W. Selected measures of selenium status in full-term and preterm neonates, their mothers and nonpregnant women. Nutrition Research, v. 13, n. 8, p. 901911, ago. 1993.

MATHEWS, F.; NEIL, H. A. W. Nutrient intakes during pregnancy in a cohort of nulliparous women. Journal of Human Nutrition and Dietetics, v. 11, n. 2, p. 151-161, abr. 1998.

MISTRY, H. D. et al. Reduced selenium concentrations and glutathione peroxidase activity in preeclamptic pregnancies. Hypertension, v. 52, n. 5, p. 881-888, nov. 2008.

MOORE, M. A. et al. Selenium supplementation of Chinese women with habitually low selenium intake increases plasma selenium, plasma glutathione peroxidase activity, and milk selenium, but not milk glutathione peroxidase activity. The Journal of Nutritional

Biochemistry, v. 11, n. 6, p. 341-347, jun. 2000. 
NEGRO, R. et al. The influence of selenium supplementation on postpartum thyroid status in pregnant women with thyroid peroxidase autoantibodies. The Journal of Clinical Endocrinology and Metabolism, v. 92, n. 4, p. 1263-1268, abr. 2007.

$\mathrm{NICHOLS}$, J. A. A. et al. A survey to estimate total nutrient intake at conception - dietary and supplementary. Journal of Nutritional \& Environmental Medicine, v. 17, n. 1, p. 12-43, mar. 2008.

ODLAND, J. O. et al. Concentrations of essential trace elements in maternal serum and the effect on birth weight and newborn body mass index in sub-arctic and arctic populations of Norway and Russia. Acta Obstetricia et Gynecologica Scandinavica, v. 78, n. 7, p. 605614, ago. 1999.

PAPPAS, A.C. et al. Selenoproteins and maternal nutrition. Comparative Biochemistry and Physiology. Part B, Biochemistry and Molecular Biology, v. 151, n. 4, p. 361-372, dez. 2008.

RAYMAN, M. The importance of selenium to human health. The Lancet, v. 356, n. 9225, p. 233-241, jul. 2000.

ROBERFROID, D.L. et al. Effect of maternal multiple micronutrient supplementation on fetal growth: a double-blind randomized controlled trial in rural Burkina Faso. American Journal of Clinical Nutrition, v. 88, n. 5, p. 1330-1340, nov. 2008.

RUMIRIS, D. et al. Lower rate of preeclampsia after antioxidant supplementation in pregnant women with low antioxidant status. Hypertension in Pregnancy, v.25, n.3, p. 241-253, set. 2006.

SANDSTROM, B. Toxicity considerations when revising the Nordic Nutrition

Recommendations. The Journal of Nutrition, v. 128, s. 2, p. 372S-374S, fev. 1998.

SCHRAUZER, G. N.; SACHER, J. Selenium in the maintenance and therapy of HIV-infected patients. Chemico-biological Interactions, v. 91, n. 2-3, p. 199-205, jun. 1994.

SPINNATO, J. A.; LIVINGSTON, J. C. Prevention of preeclampsia with antioxidants: evidence from randomized trials. Clinical Obstetrics \& Gynecology, v. 48, n. 2, p. 416-429, jun. 2005.

TAN, M. et al. Changes of serum selenium in pregnant women with gestational diabetes mellitus. Biological Trace Element Research, v. 83, n. 3, p. 231-237, dez. 2001.

THOMSON, C. D. et al. Urinary selenium and iodine during pregnancy and lactation. Journal of Trace Elements in Medicine and Biology, v. 14, n. 4, p. 210-217, abr. 2001.

TURNER, R. E. et al. Comparing nutrient intake from food to the estimated average requirements shows middle- to upper-income pregnant women lack iron and possibly magnesium. Journal of the American Dietetic Association, v. 103, n. 4, p. 416-6, abr. 2003. 
UOTILA, J. T. et al. Findings on lipid-peroxidation and antioxidant function in hypertensive complications of pregnancy. British Journal of Obstetrics and Gynaecology, v. 100, n. 3 , p. 270-276, mar. 1993.

UUSITALO, L. et al. Intake of antioxidant vitamins and trace elements during pregnancy and risk of advanced beta cell autoimmunity in the child. American Journal of Clinical Nutrition, v. 88, n. 2, p. 458-464, ago. 2008.

VAN NHIEN, N. et al. Micronutrient deficiencies and anemia among preschool children in rural Vietnam. Asia Pacific Journal of Clinical Nutrition, v. 17, n. 1, p. 48-55, mar. 2008.

VILLAMOR, E. et al. A trial of the effect of micronutrient supplementation on treatment outcome, $T$ cell counts, morbidity, and mortality in adults with pulmonary tuberculosis. Journal of Infectious Diseases, v. 197, n. 11, p. 1499-U15, jun. 2008.

WORTHINGTON-WHITE, D. A.; BEHNKE M.; GROSS, S. et al. Premature infants require additional folate and vitamin B12 to reduce the severity of the anemia of prematurity.

American Journal of Clinical Nutrition, v. 60, n. 6, p. 930-935, dez. 1994.

YANG, W. et al. Nutrient intakes in women and congenital diaphragmatic hernia in their offspring. Birth Defects Research. Part A, Clinical and Molecular Teratology, v. 82, n. 3, p. 131-138, mar. 2008.

ZACHARA, B. A. et al. Selenium levels in kidney, liver and heart of newborns and infants. Early Human Development, v. 63, n. 2, p. 103-111, jul. 2001.

ZACHARA, B. A.; PILECKI, A. Selenium concentration in the Milk of breast-feeding mothers and its geographic distribution, Environmental Health Perspectives, v. 108, n. 11, p. 10431046, nov. 2000.

\section{REFERÊNCIAS DOS ESTUDOS SELECIONADOS PARA A LEITURA NA ÍNTEGRA}

$\mathrm{BRO}$, S. et al. Serum selenium concentration in maternal and umbilical cord blood. Relation to course and outcome of pregnancy. Journal of Trace Elements and Electrolytes in Health and Disease, v. 2, n. 3, p. 165-169, set. 1988.

DODGE, M. L. et al. Selenium supplementation increases the polyunsaturated fatty acid content of human breast milk. The Journal of Trace Elements in Experimental Medicine, v. 12, n. 1, p. 37-44, jan. 1999.

HAN, L.; ZHOU, S. Selenium supplement in the prevention of pregnancy induced hypertension. Chinese Medical Journal, v. 107, n. 11, p. 870-871, nov. 1994.

KUPKA, R. et al. Effect of selenium supplements on hemoglobin concentration and morbidity among HIV-1-infected Tanzanian women. Clinical Infectious Diseases, v. 48, n. 10, p. 1475-1478, mai. 2009.

KUPKA, R. et al. Randomized, double-blind, placebo-controlled trial of selenium supplements among HIV-infected pregnant women in Tanzania: effects on maternal and child outcomes. American Journal of Clinical Nutrition, v. 87, n. 6, p. 1802-1808, jun. 2008. 
LI, Q. et al. Effects of maternal multimicronutrient supplementation on the mental development of infants in rural western China: follow-up evaluation of a double-blind, randomized, controlled trial. Pediatrics, v. 123, n. 4, p. e685-692, abr. 2009.

LOMBECK, I.; JOCHUM, F.; TERWOLBECK, K. Selenium status in infants and children with phenylketonuria and in maternal phenylketonuria. European Journal of Pediatrics, v. 155, s. 1, p. S140-S144, jul. 1996.

MOORE, M. A. et al. Selenium supplementation of Chinese women with habitually low selenium intake increases plasma selenium, plasma glutathione peroxidase activity, and milk selenium, but not milk glutathione peroxidase activity. The Journal of Nutritional Biochemistry, v. 11, n. 6, p. 341-347, jun. 2000.

NEGRO, R. et al. The influence of selenium supplementation on postpartum thyroid status in pregnant women with thyroid peroxidase autoantibodies. The Journal of Clinical Endocrinology and Metabolism, v. 92, n. 4, p. 1263-1268, abr. 2007.

THOMSON, C. D. et al. Urinary selenium and iodine during pregnancy and lactation.

Journal of Trace Elements in Medicine and Biology, v. 14, n. 4, p. 210-217, abr. 2001.

\section{REFERÊNCIAS DOS ESTUDOS SELECIONADOS PARA A LEITURA DOS MÉTODOS}

DISON, P. J. et al. Influence of maternal factors on cord and neonatal plasma micronutrient levels. American Journal of Perinatology, v. 10, n. 1, p. 30-35, jan. 1993.

SCHRAUZER, G. N.; SACHER, J. Selenium in the maintenance and therapy of HIV-infected patients. Chemico-biological Interactions, v. 91, n. 2-3, p. 199-205, jun. 1994.

\section{REFERÊNCIAS DOS ESTUDOS SUBMETIDOS À ANÁLISE DE QUALIDADE}

DODGE, M. L. et al. Selenium supplementation increases the polyunsaturated fatty acid content of human breast milk. The Journal of Trace Elements in Experimental Medicine, v. 12, n. 1, p. 37-44, jan. 1999.

HAN, L.; ZHOU, S. Selenium supplement in the prevention of pregnancy induced hypertension. Chinese Medical Journal, v. 107, n. 11, p. 870-871, nov. 1994.

MOORE, M. A. et al. Selenium supplementation of Chinese women with habitually low selenium intake increases plasma selenium, plasma glutathione peroxidase activity, and milk selenium, but not milk glutathione peroxidase activity. The Journal of Nutritional Biochemistry, v. 11, n. 6, p. 341-347, jun. 2000.

NEGRO, R. et al. The influence of selenium supplementation on postpartum thyroid status in pregnant women with thyroid peroxidase autoantibodies. The Journal of Clinical Endocrinology and Metabolism, v. 92, n. 4, p. 1263-1268, abr. 2007.

THOMSON, C. D. et al. Urinary selenium and iodine during pregnancy and lactation. Journal of Trace Elements in Medicine and Biology, v. 14, n. 4, p. 210-217, 2001. 